\title{
Analyses of HAZEN Corrosion Coupons, Rev. 1 (U)
}

\author{
K. H. Subramanian
}

Savannah River National Laboratory Strategic Materials Technology Department

Materials Technology Section

Publication Date: April 2006

\section{Westinghouse Savannah River Company Savannah River Site Aiken, SC 29808}

This document was prepared in connection with work done under Contract No. DE-AC09-96SR18500 with the U. S. Department of Energy 
WSRC-TR-2006-00142, Rev. 1

\section{DISCLAIMER}

This report was prepared as an account of work sponsored by an agency of the United States Government. Neither the United States Government nor any agency thereof, nor any of their employees, makes any warranty, express or implied, or assumes any legal liability or responsibility for the accuracy, completeness, or usefulness of any information, apparatus, product, or process disclosed, or represents that its use would not infringe privately owned rights. Reference herein to any specific commercial product, process, or service by trade name, trademark, manufacturer, or otherwise does not necessarily constitute or imply its endorsement, recommendation, or favoring by the United States Government or any agency thereof. The views and opinions of authors expressed herein do not necessarily state or reflect those of the United States Government or any agency thereof. 
DOCUMENT: $\quad$ WSRC-TR-2006-00142, Rev. 1

TITLE: $\quad$ Analysis of HAZEN Corrosion Coupons (U)

\section{APPROVALS}

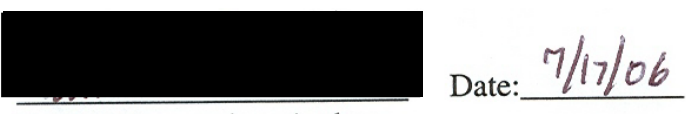

K. H. Subramanian, Author

Materials Performance and Corrosion Technology

Materials Science and Technology Directorate

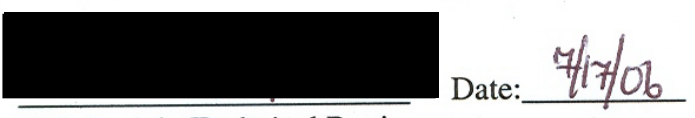

K. J. Imrich, Technical Reviewer

Materials Performance and Corrosion Technology

Materials Science and Technology Directorate

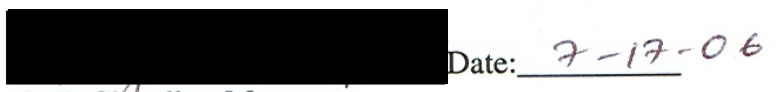

G. T. Chandler, Manager

Materials Performance and Corrosion Technology

Materials Science and Technology Directorate

N. C. Iyer, Manager

Date: $7 / 17 / 06$

Materials Science and Technology Directorate Savannah River National Laboratory 


\section{Table of Contents}

1

SUMMARY

1

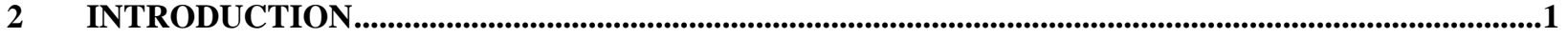

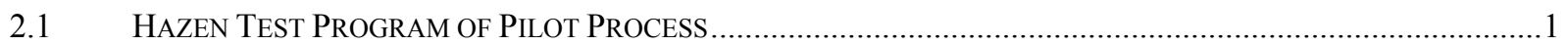

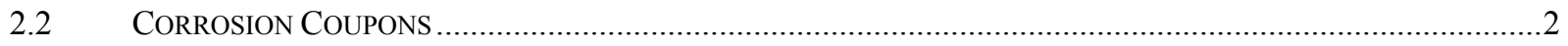

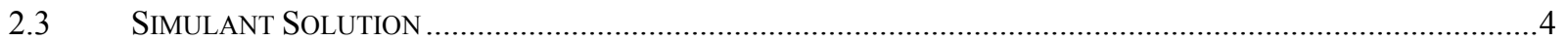

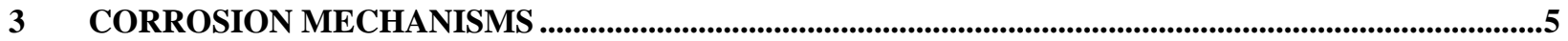

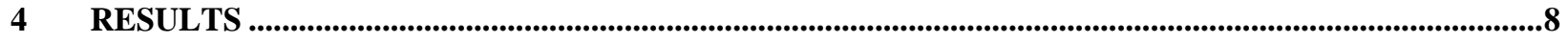

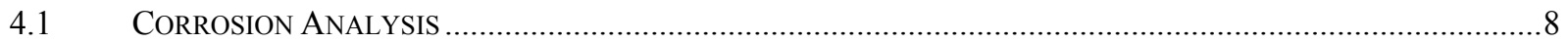

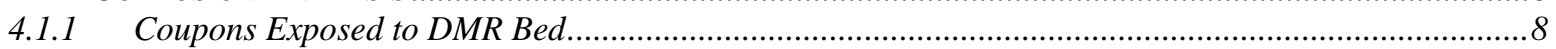

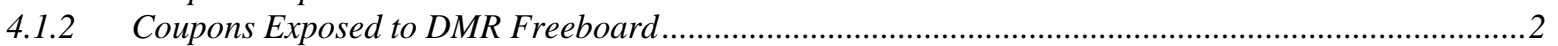

4.1.3 Coupons Exposed to HTF Dirty Side .............................................................................................2

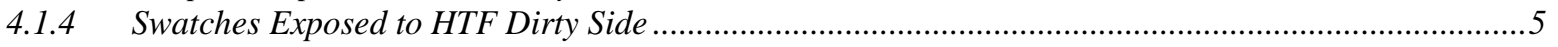

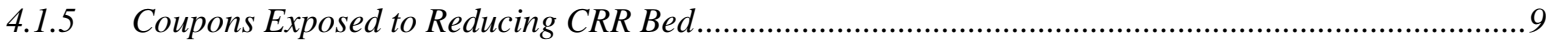

4.1.6 Coupons Exposed to Oxidizing CRR Bed ....................................................................................14

4.1.7 Coupons Exposed to CRR Freeboard ............................................................................................16

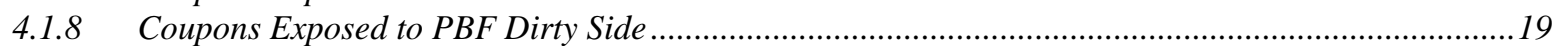

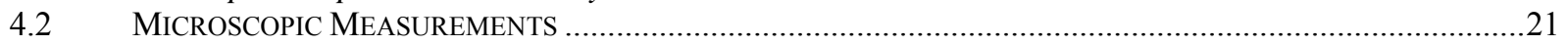

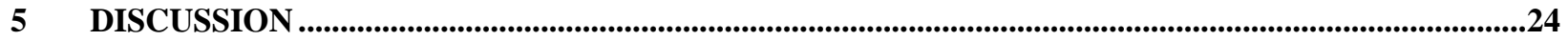

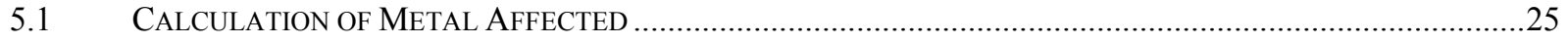

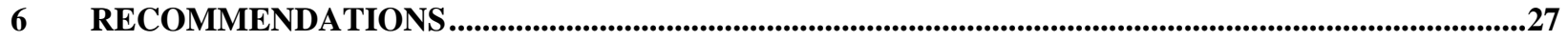

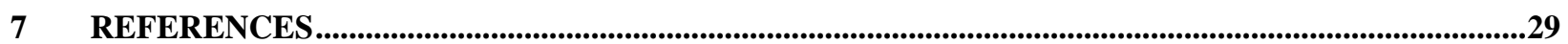




\section{$\underline{\text { List of Tables }}$}

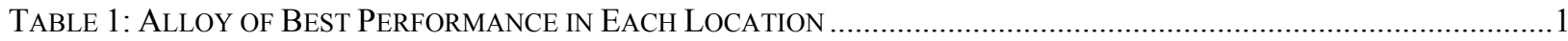

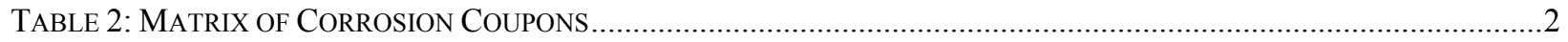

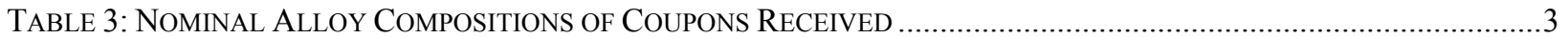

TABLE 4: SUPERNATE SiMULANT SOLUTION AND FEEDSTOCK UNDISSOLVED SOLIDS ..............................................

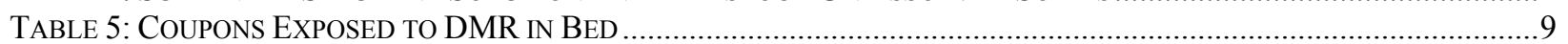

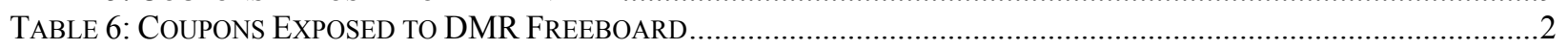

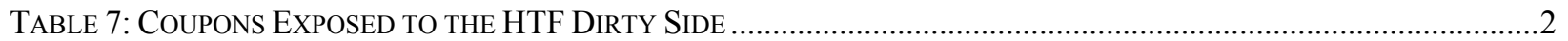

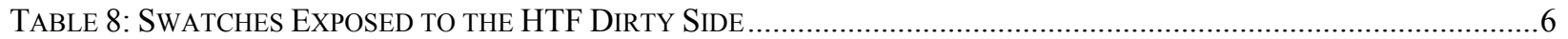

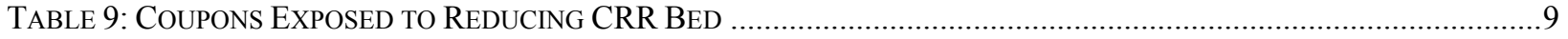

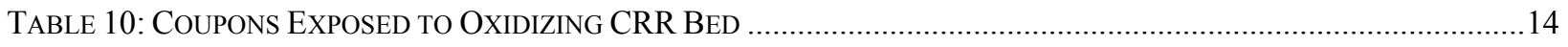

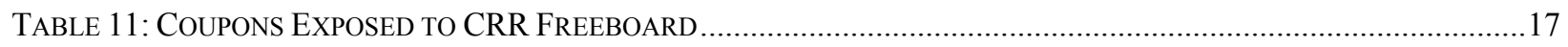

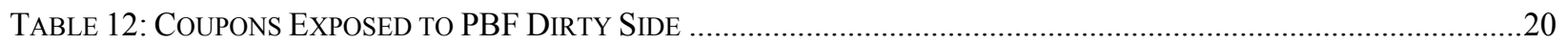

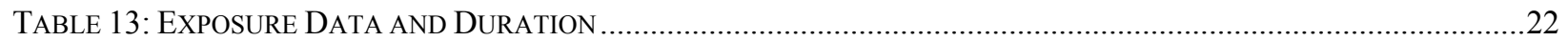

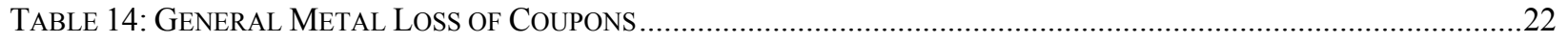

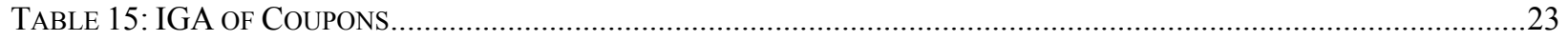

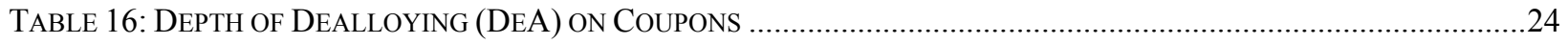

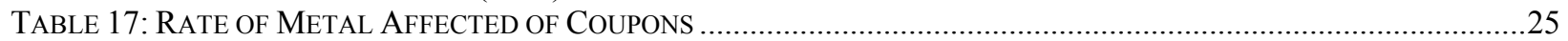

TABLE 18: CALCULATION OF CORROSION RATE PER HOUR OF OPERATION .........................................................26

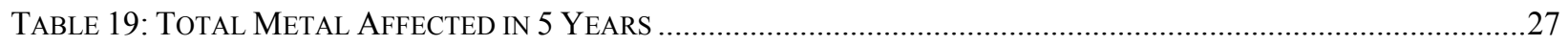

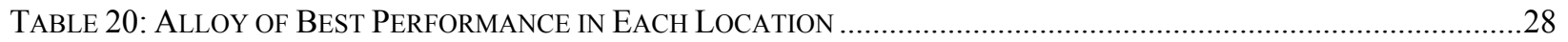

\section{$\underline{\text { List of Figures }}$}

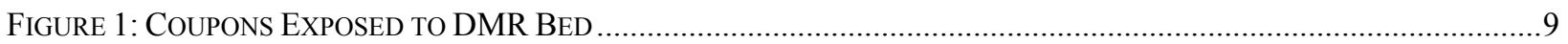

Figure 2: Metallographic Cross SeCtion of Coupon 1A - Haynes 556 Alloy EXPosed to DMR Bed ...........10

Figure 3: Metallographic Cross SeCtion of Coupon 2C - Haynes HR-160 Alloy Exposed to DMR Bed....11

Figure 4: Metallographic Cross SeCtion of COUPON 3E - HAYNES 230 Alloy EXPoSED to DMR BeD............11

Figure 5: METALlographic Cross SeCtion of COUPON 4G - 316L EXPOSED TO DMR BED .................................11

FigURE 6: SEM/EDX OF HA-556 Alloy EXPOSED to DMR BED INDICATING ASH-TYPE DEPOSIT AND UNDERLYING

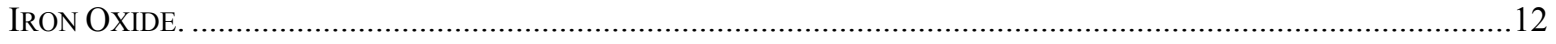

FiguRE 7: SEM/EDX of HR-160 Alloy EXPOSED to DMR BED INDICATING ASH-TyPe DEPOSIT AND SULFIDE

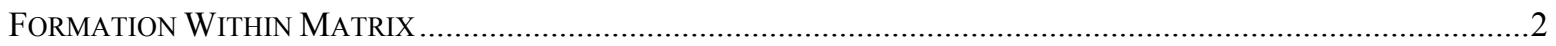

Figure 8: SEM/EDX OF HA-230 Alloy EXPOSED to DMR BED INDICATING ASH-TyPe DEPOSIT AND SULFIDE

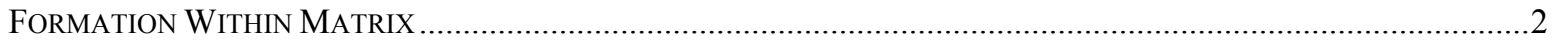

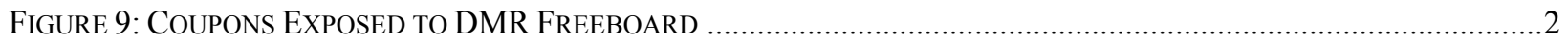

Figure 10: Metallographic Cross SECTION OF COUPON 1D - HAYNeS 556 Alloy EXPOSED to DMR FreEbOARD

Figure 11: Metallographic Cross Section of Coupon 2F - HAYNes HR-160 Alloy EXPosed to DMR

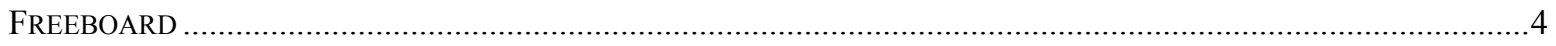

Figure 12: Metallographic Cross SeCtion of COUPON 3H - HAYNes 230 Alloy EXPOSED to DMR FreEbOARD

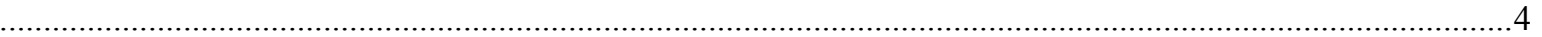

Figure 13: METALlOGRAPHIC CROSS SECTION OF COUPON 4B - 316L SS EXPOSED to DMR FREEBOARD ...................

FiguRE 14: SEM/EDX of HA-556 Alloy EXPOSED to DMR BED INDICATING ASH-TyPE DEPOSIT AND

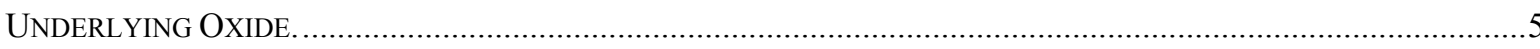

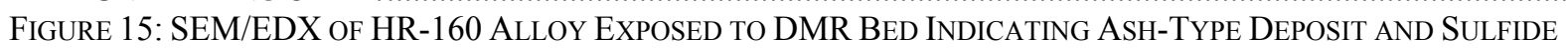

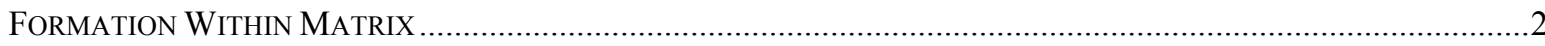

Figure 16: SEM/EDX OF HA-230 Alloy EXPOSED to DMR BED INDICATING ASH-TYPe DEPOSIT AND SUlFidE

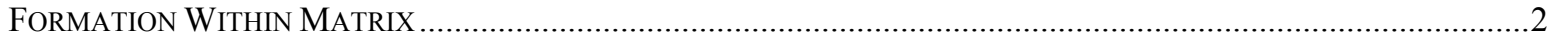

FIGURE 17: COUPONS EXPOSED TO THE HTF DIRTY SIDE ..............................................................................

Figure 18: Metallographic Cross Section of Coupon 1E - Haynes 556 Alloy EXPoSed to HTF DirTy Side.4 Figure 19: Metallographic Cross Section of COUPON 2G - HAynes HR-160 Alloy EXPOSED to HTF DirTy SIDE

Figure 20: Metallographic Cross Section of Coupon 3A - Haynes 230 Alloy EXPoSed to HTF DirTy Side 4 
Figure 21: Metallographic Cross Section of Coupon 4C - 316L SS Alloy EXPosed to HTF Dirty Side........5

FIGURE 22: SWATCHES EXPOSED TO THE HTF DIRTY SIDE....................................................................................

Figure 23: Metallographic Cross Section of Porvair InCONEl 601 Filter SWATCh EXPOSED to HTF DiRTy SIDE.

Figure 24: Metallographic Cross Section of Mott InCONEl 601 Filter SWATCH EXPOSED to HTF DirTy

SIDE.

Figure 25: Metallographic Cross Section of Mott Alloy HR Filter SWATCh EXPOSED to HTF DiRTy Side 8

Figure 26: Metallographic Cross Section of Pall InConel 601 Swatch EXPosed to HTF DirTy Side ...........8

FIGURE 27: COUPONS EXPOSED TO CRR BED ………...........................................................................................

Figure 28: METAllographic Cross SeCtion OF COUPON 1H - HAYNES 556 Alloy EXPOSED to CRR ReduCing10

Figure 29: Metallographic Cross Section of COUPON 2A - HAynes HR-160 Alloy EXPosed to CRR

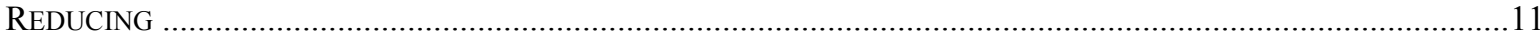

Figure 30: Metallographic Cross Section of Coupon 3C - Haynes 230 Alloy EXPosed to CRR Reducing

Figure 31: MetallograPHIC CROSS SECTION OF COUPON 1H - HAYNES 556 Alloy EXPOSED TO CRR REDUCING

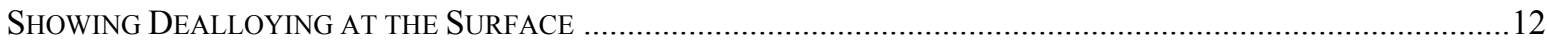

Figure 32: SEM/EDX OF HAYNES 556 ALLOY EXPOSED TO DMR BED INDICATING LACK OF STABLE OXIDE ON

SURFACE .......................................................................................................................... 13

Figure 33: SEM/EDX OF HAYNES HR-160 Alloy EXPOSED to DMR BED INDICATING STABLE OXIDE ON SURFACE

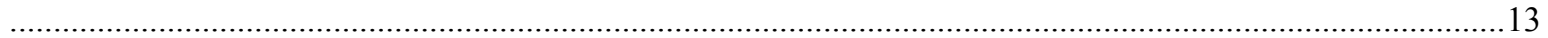

FiguRE 34: SEM/EDX OF HAYNES 230 ALlOY EXPOSED TO DMR BED INDICATING STABLE OXIDE ON SURFACE....14

Figure 35: Metallographic Cross SeCtion of COUPON 1J - HAYNES 556 Alloy EXPosed to CRR OXidizing. 15

Figure 36: Metallographic Cross Section of COUPON 2L - HAYNeS HR-160 Alloy EXPoSed to CRR

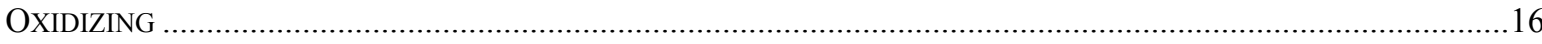

Figure 37: Metallographic Cross SeCtion of COUPON 3N - HAynes 230 Alloy EXPoSED to CRR OXIDIZING

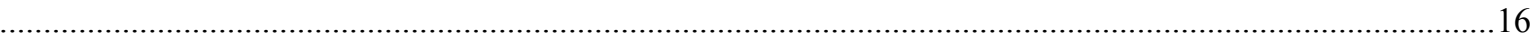

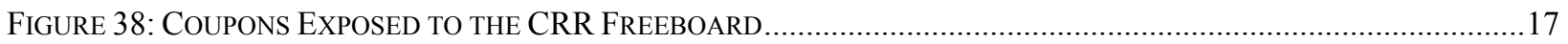

Figure 39: Metallographic Cross Section of Coupon 1L - HAynes 556 Alloy EXPoSEd to CRR FreeboARD

Figure 40: Metallographic Cross Section of COUPON $2 \mathrm{O}$ - HAynes Alloy HR-160 EXPOSED to CRR

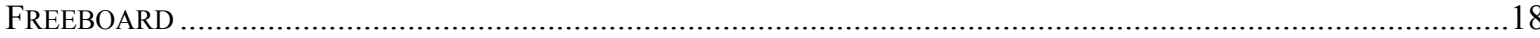

Figure 41: Metallographic Cross SeCtion of COUPON 3K - Haynes 230 Alloy EXPoSed to CRR FreEboARD

FIGURE 42: COUPON EXPOSED IN THE PBF

Figure 43: Metallographic Cross Section of Coupon 8B - Alloy AL6XN EXPosed to PBF Dirty Side ......21

Figure 44: METALLOGRAPHIC CRosS SECTION OF COUPON 9D - 317SS EXPOSED to PBF DiRTY SidE......................21

Figure 45: Metallographic Cross SeCtion of COUPON 4F - 316L SS EXPOSED TO PBF DirTY Side ....................21

Figure 46: MEASUREMENTS AND CAlCUlation of DePTH of PENETRation (ACKNOWLEDGEMENT: Haynes Alloy 230 BROCHURE). 


\section{SUMMARY}

Pilot scale system/process testing of the THOR ${ }^{\mathrm{sm}}$ treatment process is being conducted to support the full-scale process system design, optimization, validation, and permitting activities. The Savannah River National Laboratory has completed analysis of corrosion coupons placed within various locations of the pilot scale process system in order to determine the most suitable materials of construction.

The alloy that performed the best in a given location of the THOR ${ }^{\mathrm{sm}}$ treatment process is shown in Table 1 . Recommendations on alloy selection for each section of the process were made based upon the cumulative metal loss in a coupon referred to herein as metal affected data. The cumulative metal loss i.e. metal affected data were used to calculate a corrosion rate per hour of operation based upon location-specific exposure. The calculations used to recommend the alloys assumed that each of the coupons in the various locations was installed (mounted) such that they were equivalently exposed. The results and the deposits analysis however do indicate that orientation or placement in the system plays a key role in the corrosion of the coupons. It appears that several coupons were most likely protecting other coupons from corrosion. The data in Table 1 can be used to calculate a corrosion allowance based upon a customer-defined safety factor.

Table 1: Alloy of Best Performance in Each Location

\begin{tabular}{|c|c|c|}
\hline Location & Alloy & $\begin{array}{c}\text { Corrosion Rate per hour } \\
\text { of operation(in./hr) }\end{array}$ \\
\hline DMR in Bed & HA556 & $5.71 \mathrm{E}-07$ \\
\hline DMR Freeboard & HA556 & $1.66 \mathrm{E}-06$ \\
\hline CRR in Bed (RED) & Haynes 230 & $6.62 \mathrm{E}-06$ \\
\hline CRR in Bed (OX) & N/A & $\begin{array}{c}\text { Needs protection with high } \\
\text { temperature refractory }\end{array}$ \\
\hline CRR Freeboard & Haynes 556 & $6.69 \mathrm{E}-06$ \\
\hline HTF Dirty Side & Haynes 556 & $1.10 \mathrm{E}-06$ \\
\hline PBF Dirty Side & AL6XN & $3.16 \mathrm{E}-06$ \\
\hline
\end{tabular}

\section{INTRODUCTION}

Pilot scale system/process testing of the $\mathrm{THOR}^{\mathrm{sm}}$ treatment process is being conducted to support the full-scale process system design, optimization, validation, and permitting activities. A corrosion surveillance test program was implemented in order to identify and validate the most suitable materials of construction for the full-scale production plant,. Corrosion coupons have been exposed at various locations of the process equipment and thereby subjected to thermal and chemical environments typical of the potentially corrosive process operating conditions. The Savannah River National Laboratory has been contracted to analyze the corrosion of these coupons. The analysis has been completed and is presented herein.

\subsection{Hazen Test Program of Pilot Process}

The Hazen Test Program included the installation of corrosion coupons throughout various locations of the pilot system.[1] The corrosion mechanisms that are manifested in each of the process sections are a complex function of environments, temperature and metallurgy of the specific alloys. The following sections provide a summary of each of the environments, potential consequent corrosion mechanisms and the effect of metallurgy on the performance in each of the process sections. The pilot scale system and process flow diagram is described in detail in Reference 1, and are summarized here for the specific locations of interest for the installed corrosion coupons.[1] The specific locations of interest for this analysis were the denitration and mineralization (DMR) bed, high temperature filter area (HTF), the carbon reduction reformer (CRR), and the process baghouse filter (PBF).

The DMR is a fluidized bed vessel designed to operate in an autothermal steam reforming mode to evaporate water; reduce nitrates to nitrogen; volatilize and reform organics; convert alkali and alkaline earth metals into non- 
agglomerating solid products; and capture sulfur, fluoride, chloride, and phosphate compounds in the solid product. Non-volatile heavy metals, other metals, and the non-radioactive radionuclide surrogates, i.e., Cerium and Cesium, are also captured in the solid product. The High Temperature Filter (HTF) is a filter vessel that receives the process gases and entrained fines from the DMR. The purpose of the HTF is to remove and collect essentially all of the finely divided solids elutriated from the DMR. The filtered DMR process gas consists mainly of water vapor, nitrogen, carbon dioxide, carbon monoxide, hydrogen, methane and other short-chain organics, and small amounts of acidic gases such as hydrochloric acid and sulfur dioxide. This process gas mixture is introduced at the bottom of the CRR and fluidizes the bed media. An oxygen/air mixture is injected through a second set of gas distributors positioned approximately 12" above the fluidizing gas distributors through which the DMR process gases flow into the CRR. The oxygen/air injection distributors create an oxidizing steam reforming environment in the upper section of the fluidized bed and in the CRR freeboard. The CRR fully oxidizes the hydrogen, carbon monoxide, and organics from the DMR, converting them to carbon dioxide and water and generating heat.

\subsection{Corrosion Coupons}

The corrosion testing plan included installation of metal alloy coupons in the process equipment to monitor corrosion during pilot scale testing. The coupons were nominal $2 \times 1$-in coupons with a nominal thickness of 0.125 in. The coupons with their location in the process system, coupon designation, material, serial number, and CMTR\# are listed in Table 2.

Table 2: Matrix of Corrosion Coupons

\begin{tabular}{|c|c|c|c|c|}
\hline LOCATION & COUPON & MATERIAL & SERIAL \# & CMTR \# \\
\hline \multirow{4}{*}{ Denitration and Mineralization Reformer (DMR) in Bed } & $1 \mathrm{~A}$ & Haynes 556 & 7 & COL 365800054100 \\
\hline & $2 \mathrm{C}$ & Haynes HR-160 & 7 & COL 369210054100 \\
\hline & $3 \mathrm{E}$ & Haynes 230 & 7 & COL 365780054100 \\
\hline & $4 \mathrm{G}$ & 316L SS & 3 & COL 361590314100 \\
\hline \multirow{4}{*}{ DMR Freeboard } & 1D & Haynes 556 & 10 & COL 365800054100 \\
\hline & $2 \mathrm{~F}$ & Haynes HR-160 & 10 & COL 369210054100 \\
\hline & $3 \mathrm{H}$ & Haynes 230 & 10 & COL 365780054100 \\
\hline & 4B & 316L SS & 6 & COL 361590314100 \\
\hline \multirow{4}{*}{ High Temperature Filter (HTF) Dirty Side } & $1 \mathrm{E}$ & Haynes 556 & 1 & COL 365800054100 \\
\hline & $2 \mathrm{G}$ & Haynes HR-160 & 1 & COL369210054100 \\
\hline & $3 \mathrm{~A}$ & Haynes 230 & 1 & COL365780054100 \\
\hline & $4 \mathrm{C}$ & 316L SS & 1 & COL 361590314100 \\
\hline \multirow{5}{*}{$\begin{array}{c}\text { HTF Dirty Side Swatches } \\
\text { (With New Sample PC for measuring thickness) }\end{array}$} & 1 Hole & Porvair Inconel 601 & 1 & MA5 GRN 44552 \\
\hline & 2 Hole & Porvair Alloy VDM & 1 & $\begin{array}{l}5923 \text { MA3 GRN } \\
92747\end{array}$ \\
\hline & 3 Hole & Mott Inconel 601 & 1 & N/A \\
\hline & 4 Hole & Mott Alloy HR & 1 & $\mathrm{~N} / \mathrm{A}$ \\
\hline & 5 Hole & Pall Inconel 601 & 1 & M434020 \\
\hline \multirow[t]{2}{*}{ Carbon Reduction Reformer (CRR) in Bed: Reducing } & $1 \mathrm{H}$ & Haynes 556 & 4 & COL 365800054100 \\
\hline & $2 \mathrm{~A}$ & Haynes HR-160 & 4 & COL 369210054100 \\
\hline
\end{tabular}


WSRC-TR-2006-00142, Rev. 1

\begin{tabular}{|c|c|c|c|c|}
\hline LOCATION & COUPON & MATERIAL & SERIAL \# & CMTR \# \\
\hline & $3 \mathrm{C}$ & Haynes 230 & 3 & COL 365780054100 \\
\hline \multirow{3}{*}{ CRR in Bed: Oxidizing } & $1 \mathrm{~J}$ & Haynes 556 & 5 & COL 365800054100 \\
\hline & $2 \mathrm{~L}$ & Haynes HR-160 & 5 & COL 369210054100 \\
\hline & $3 \mathrm{~N}$ & Haynes 230 & 5 & COL 365780054100 \\
\hline \multirow{3}{*}{ CRR Freeboard } & $1 \mathrm{~L}$ & Haynes 556 & 12 & COL 365800054100 \\
\hline & $2 \mathrm{O}$ & Haynes HR-160 & 12 & COL 369210054100 \\
\hline & $3 \mathrm{~K}$ & Haynes 230 & 12 & COL 365780054100 \\
\hline \multirow{3}{*}{ Process Baghouse Filter (PBF) Dirty Side } & $8 \mathrm{~B}$ & AL6XN & 4 & COL 363440314100 \\
\hline & 9D & $317 \mathrm{SS}$ & 3 & COL 361660314100 \\
\hline & $4 \mathrm{~F}$ & 316L SS & 8 & COL 361590314100 \\
\hline
\end{tabular}

The nominal compositions of each of the materials exposed are shown in Table 3.

Table 3: Nominal Alloy Compositions of Coupons Received

\begin{tabular}{|c|c|c|c|c|c|c|c|c|c|c|c|c|c|c|c|c|}
\hline \multirow[t]{2}{*}{ Material } & \multicolumn{16}{|c|}{ Compositions } \\
\hline & $\mathrm{Fe}$ & $\mathrm{Cr}$ & $\mathrm{Ni}$ & Co & Mo & W & Mn & Ta & $\mathbf{C} \mathbf{u}_{\max }$ & $\mathbf{T i}$ & $\mathrm{Si}$ & $\mathbf{N}$ & Al & $\mathbf{C}_{\max }$ & $\mathrm{Zr}$ & La \\
\hline Haynes 556 & 31 & 22 & 20 & 18 & 3 & 2.5 & 1 & 0.6 & & & 0.4 & 0.2 & 0.2 & 0.1 & 0.02 & 0.02 \\
\hline $\begin{array}{c}\text { Haynes HR- } \\
160\end{array}$ & 2 & 28 & 37 & 29 & 1 & 1 & 0.5 & & & 0.5 & 2.75 & & & & & \\
\hline Haynes 230 & 3 & 22 & 57 & 5 & 2 & 14 & 0.5 & & & & 0.4 & & 0.3 & 0.1 & 0.02 & 0.02 \\
\hline $\begin{array}{c}\text { Porvair } \\
\text { Inconel } 601\end{array}$ & Bal & $\begin{array}{l}21- \\
25\end{array}$ & $\begin{array}{l}58- \\
63\end{array}$ & & & & 1.0 & & 1.0 & & 0.5 & & $\begin{array}{l}1- \\
1.7\end{array}$ & 0.1 & & \\
\hline $\begin{array}{c}\text { Porvair Alloy } \\
\text { VDM }\end{array}$ & \multicolumn{16}{|c|}{ N/A } \\
\hline $\begin{array}{c}\text { Mott Inconel } \\
601\end{array}$ & Bal & $\begin{array}{l}21- \\
25\end{array}$ & $\begin{array}{l}58- \\
63\end{array}$ & & & & 1.0 & & 1.0 & & 0.5 & & $\begin{array}{l}1- \\
1.7\end{array}$ & 0.1 & & \\
\hline $\begin{array}{c}\text { Mott Alloy } \\
\text { HR }\end{array}$ & \multicolumn{16}{|c|}{ N/A } \\
\hline $\begin{array}{l}\text { Pall Inconel } \\
\quad 601\end{array}$ & Bal & $\begin{array}{l}21- \\
25\end{array}$ & $\begin{array}{l}58- \\
63\end{array}$ & & & & 1.0 & & 1.0 & & 0.5 & & $\begin{array}{c}1- \\
1.7\end{array}$ & 0.1 & & \\
\hline AL6XN & Bal & 20 & 24 & & 6.2 & & 0.4 & & 0.2 & & 0.4 & 0.22 & & 0.02 & & \\
\hline 317 SS & Bal & $\begin{array}{l}18- \\
20 \\
\end{array}$ & $\begin{array}{l}11- \\
14 \\
\end{array}$ & & $3-4$ & & 2 & & & & 0.75 & & & 0.8 & & \\
\hline 316L SS & Bal & 17 & 12 & & 2.5 & & 2 & & & & 1 & & & 0.03 & & \\
\hline
\end{tabular}

The Haynes 556, Haynes HR-160, and Haynes 230 alloys were selected as candidate materials of construction for the DMR, HTF Area and the CRR. The Haynes 556 is an iron-nickel-chromium-cobalt alloy, while the HR-160 is a solid-solution strengthened nickel-cobalt-chromium-silicon alloy. The Haynes 230 alloy is a nickel-chromiumtungsten-molybdenum alloy. The Haynes 556/HR-160 nickel based alloys are inherently resistant to many acids and alkalis, thereby providing a good basis for development of specialized alloys. The Haynes 556 alloy is considered a 
Fe-based alloy with significant alloying additions of cobalt and some molybdenum.

Each of these alloys has specific alloying components that enhance corrosion resistance in specific environments.[2] The Haynes HR-160 alloy has significant amounts of chromium, nickel and cobalt, and is typically expected to be most resistant of the alloys exposed to sulfidizing environments. The Haynes 556 alloy is typically recommended for resistance to carburizing and molten salt chloride containing environments. However, the Haynes 230 is typically recommended for very high temperature oxidizing or nitriding environments.

Each of the alloying elements in these materials is expected to impart specific corrosion resistance of the materials.[3] The chromium additions to the alloys are critical to the formation of a tenaciously bound and protective $\mathrm{Cr}_{2} \mathrm{O}_{3}$ layer. It is this oxide layer that provides the protection against further corrosion damage. The molybdenum and tungsten additions provide strength at high temperatures, corrosion resistance to non-oxidizing acids, and improve the localized corrosion resistance.[4] The cobalt addition functions similar to nickel at low temperatures, however, at higher temperatures the cobalt will strengthen the alloy , similar to molybdenum., and increases resistance to carburization by increasing the solubility of carbon.[3] In addition, since cobalt sulfide has a higher temperature than nickel sulfide, the cobalt is known to increase high-temperature sulfidation resistance. The silicon additions, when carefully controlled to prevent carbide formation can increase the resistance to sulfuric acid corrosion, and increase high temperature corrosion resistance through the formation of an underlying silicon oxide layer.[5] The silicon oxide typically forms at temperatures greater than $800^{\circ} \mathrm{C}$.

The metal filter systems tested were made of Inconel 601, VDM alloy, and a HR alloy metals that are supported on a mesh. The metal filter systems are nickel based alloys with additions of chromium and potentially aluminum to provide the corrosion resistance. The corrosion in these filters is often a complex synergistic effect of surface area effects, under-deposit corrosion, and potentially galvanic effects.

The coupons exposed to the PBF included standard 316L stainless steel, 317 stainless steel, and AL6XN superaustentic stainless steel alloy coupons. The standard 316L stainless steel alloy has additions of chromium and nickel, while maintaining a low carbon content to prevent the formation of carbides, and increasing the resistance to intergranular attack. In addition, molybdenum is added to further increase the resistance to intergranular attack and general corrosion. The 317 stainless steel and the AL6XN alloys have progressively increasing chromium, nickel, and molybdenum concentrations thereby increasing their corrosion resistance.

\subsection{Simulant Solution}

The materials selection for this specific application is challenging due to the aggressiveness and the variability in the exposures in each section of the process. Each of the coupons exposed to the various sections of the process had significant process deposits known to be extremely aggressive, particularly at the temperatures of exposures.

Table 4: Supernate Simulant Solution and Feedstock Undissolved Solids

\begin{tabular}{|c|c|c|}
\hline Component & Reagent & Conc. (M/l, ppm) \\
\hline \multicolumn{3}{|l|}{ Cations } \\
\hline Acid & $\mathrm{HNO}_{3}($ See Nitrate) & 3.06 \\
\hline Aluminum & $\mathrm{Al}\left(\mathrm{NO}_{3}\right)_{3} \cdot 9 \mathrm{H}_{2} \mathrm{O}$ & $0.719,14900$ \\
\hline Boron & $\mathrm{H}_{3} \mathrm{BO}_{3}$ & $0.0217,180$ \\
\hline Calcium & $\mathrm{Ca}\left(\mathrm{NO}_{3}\right)_{2} \cdot 4 \mathrm{H}_{2} \mathrm{O}$ & $0.0731,2250$ \\
\hline Iron & $\mathrm{Fe}\left(\mathrm{NO}_{3}\right)_{3} \cdot 9 \mathrm{H}_{2} \mathrm{O}$ & $0.0217,932$ \\
\hline Magnesium & $\mathrm{Mg}\left(\mathrm{NO}_{3}\right)_{2} \cdot 6 \mathrm{H}_{2} \mathrm{O}$ & $0.0257,480$ \\
\hline Manganese & $\begin{array}{c}\mathrm{Mn}\left(\mathrm{NO}_{3}\right)_{2} \\
(50 \mathrm{wt} \% \text { sol'n, } \rho=1.54)\end{array}$ & $0.0152,642$ \\
\hline Potassium & $\mathrm{KNO}_{3}$ & $0.225,6770$ \\
\hline
\end{tabular}


WSRC-TR-2006-00142, Rev. 1

\begin{tabular}{|c|c|c|}
\hline Sodium & $\mathrm{NaNO}_{3}$ & $2.20,38900$ \\
\hline \multicolumn{3}{|l|}{ Anions } \\
\hline Chloride & $\mathrm{NaCl}$ & 0.0334 \\
\hline Fluoride & HF (28.9 M sol'n) & 0.0506 \\
\hline Nitrate & $\begin{array}{c}\mathrm{HNO}_{3} \\
(69 \mathrm{wt} \% \text { sol'n, } \rho=1.41)\end{array}$ & 7.53 \\
\hline Phosphate & $\mathrm{Na}_{3} \mathrm{PO}_{4} \cdot 12 \mathrm{H}_{2} \mathrm{O}$ & 0.0138 \\
\hline Sulfate & $\mathrm{Na}_{2} \mathrm{SO}_{4}$ & 0.107 \\
\hline Component & Reagent & Concentration (wt\%) \\
\hline \multicolumn{3}{|c|}{ Undissolved Solids } \\
\hline Aluminum & $\mathrm{Al}_{2} \mathrm{O}_{3} \cdot 2 \mathrm{SiO}_{2}$ (kaolin) & 2.2 \\
\hline Iron & $\mathrm{Fe}_{2} \mathrm{SiO}_{4}$ & 2.6 \\
\hline Silicon & $\begin{array}{l}\text { Amorphous Silica } \\
\text { Ground Quartz }\end{array}$ & 24.3 \\
\hline $\begin{array}{l}\text { Zirconium } \\
\text { Phosphate }\end{array}$ & $\mathrm{Zr}\left(\mathrm{HPO}_{4}\right)_{2}$ & $\begin{array}{l}13.1 \\
27.2 \\
\end{array}$ \\
\hline
\end{tabular}

The key environmental factors potentially affecting the corrosion response of the coupons include the corrosive vapors as well as any process deposits on the coupons. These deposits and corrosive vapors are a function of the temperatures and the initial concentrations of the test feedstock materials. The feedstock for the test program included the following major corrosive anionic species: (1) chloride, (2) fluoride, (3) nitrate, (4) phosphate, and (5) sulfate. These constituents with a basic knowledge of the process application were used to determine the potential corrosion mechanisms in each section of the process.

\section{CORROSION MECHANISMS}

There are several corrosion modes that are possible due to exposure to the aggressive environments in the treatment process. The corrosion may manifest itself as general corrosion and/or contribute to localized corrosion effects including pitting and stress corrosion cracking.

The potential corrosion modes include:

1. Corrosion induced by surface deposits from the process such as fuel-ash type corrosion.

2. High temperature gas phase corrosion, including oxidation, sulfidation, halogen corrosion, carburization/metal dusting, and nitridation.

3. Downtime corrosion induced by high temperature hygroscopic deposits absorbing water during plant downtime.

4. Corrosion due to gaseous species reacting with condensed water to form acids.

5. Erosion or wear from mobile particulate matter or from spalled corrosion products.

6. Interaction of the degradation modes with mechanical factors, such as creep or fatigue, e.g. creep corrosion or corrosion fatigue, thermal or dynamic loadings.

The basic definition, manifestation, and case potential for this application are summarized as follows: 


\section{Fuel-Ash Type Corrosion}

\begin{tabular}{|l|l|l|l|}
\hline $\begin{array}{l}\text { Corrosion } \\
\text { Type }\end{array}$ & \multicolumn{1}{|c|}{ Definition } & \multicolumn{1}{c|}{ Manifestation } & \multicolumn{1}{c|}{ Case Potential } \\
\hline $\begin{array}{l}\text { Fuel-ash } \\
\text { Type } \\
\text { Corrosion }\end{array}$ & $\begin{array}{l}\text { Fuel-ash } \\
\text { corrosion, is the } \\
\text { oxidation of } \\
\text { metal with the } \\
\text { concurrent } \\
\text { reduction of the } \\
\text { ash, or oxygen }\end{array}$ & $\begin{array}{l}\text { General corrosion is seen as a } \\
\text { corrosion "front". }\end{array}$ & $\begin{array}{l}\text { Fuel ash corrosion can also lead } \\
\text { to localized (pitting/SCC) attack, } \\
\text { particularly in the presence of } \\
\text { trace impurities, e.g. chlorides. }\end{array}$ \\
$\begin{array}{l}\text { Sulfates and silicates were primary } \\
\text { constituents in the feed stock and } \\
\text { consequently process deposits throughout the } \\
\text { system. Fuel ash is nominally a combination } \\
\text { of silicates and sulfates as well, and can be } \\
\text { used as an analogy for corrosion analysis in } \\
\text { this application. }\end{array}$ \\
\hline
\end{tabular}

2. High-Temperature Gas Phase Corrosion

\begin{tabular}{|l|l|l|l|}
\hline \multicolumn{1}{|c|}{$\begin{array}{c}\text { Corrosion } \\
\text { Type }\end{array}$} & \multicolumn{1}{|c|}{ Definition } & \multicolumn{1}{c|}{ Manifestation } & \multicolumn{1}{c|}{ Case Potential } \\
\hline Sulfidation & $\begin{array}{l}\text { Sulfidation is } \\
\text { corrosion due to } \\
\text { gaseous sulfur } \\
\text { contamination }\end{array}$ & $\begin{array}{l}\text { General corrosion due to } \\
\text { sulfidation is seen with a } \\
\text { corrosion "front". } \\
\text { Sulfidation can result in } \\
\text { localized pitting attack. }\end{array}$ & $\begin{array}{l}\text { Sulfates are the primary } \\
\text { remaining constituent after the } \\
\text { DMR process } \\
\text { Sulfur contamination may lead } \\
\text { to formation of a low melting } \\
\text { temperature eutectic, e.g. Ni- }\end{array}$ \\
$\mathrm{Ni}_{3} \mathrm{~S}_{2},\left(\mathrm{~T}_{\mathrm{m}}=635^{\circ} \mathrm{C}\right)$
\end{tabular}


WSRC-TR-2006-00142, Rev. 1

\begin{tabular}{|c|c|c|c|}
\hline $\begin{array}{l}\text { Corrosion } \\
\text { Type }\end{array}$ & Definition & Manifestation & Case Potential \\
\hline Carburization & $\begin{array}{l}\text { Carbides form at grain } \\
\text { boundaries }\end{array}$ & $\begin{array}{l}\text { Carburization also reduces } \\
\text { oxidation resistance due to } \\
\text { chromium depletion with the } \\
\text { formation of chrome } \\
\text { carbides }\left(\mathrm{Cr}_{\mathrm{x}} \mathrm{C}_{\mathrm{y}}\right) \\
\text { Creep strength may also be } \\
\text { adversely affected and } \\
\text { internal stresses can arise } \\
\text { from the volume increase } \\
\text { associated with the carbon } \\
\text { uptake and carbide } \\
\text { formation. Localized } \\
\text { bulging is possible. }\end{array}$ & $\begin{array}{l}\text { Carburization, i.e. formation of } \\
\text { carbides) typically occurs at } \\
\text { temperatures between } 840- \\
930^{\circ} \mathrm{C} \text {. }\end{array}$ \\
\hline $\begin{array}{l}\text { Metal } \\
\text { Dusting }\end{array}$ & $\begin{array}{l}\text { Metal dusting is a } \\
\text { form of carburization }\end{array}$ & $\begin{array}{l}\text { Metal dusting can be } \\
\text { manifest as localized } \\
\text { attack/general corrosion } \\
\text { The typical corrosion } \\
\text { products are seen as fine } \\
\text { powders }\end{array}$ & $\begin{array}{l}\text { Metal dusting occurs between } \\
425 \text { and } 815^{\circ} \mathrm{C} \text {, lower than that } \\
\text { of carburization. } \\
\text { Maximum rates of metal } \\
\text { dusting damage will occur from } \\
650 \text { to } 730^{\circ} \mathrm{C} \text {. }\end{array}$ \\
\hline Nitridation & $\begin{array}{l}\text { A nitrided layer forms } \\
\text { on the surface. }\end{array}$ & $\begin{array}{l}\text { The nitrided layer }(\mathrm{CrN} \text {, } \\
\left.\mathrm{Cr}_{2} \mathrm{~N}\right) \text { reduces corrosion } \\
\text { resistance }\end{array}$ & $\begin{array}{l}\text { Nitridation typically occurs in } \\
\text { ammonia bearing environments. } \\
\text { However, nitriding would } \\
\text { require much higher } \\
\text { temperatures in a pure } \mathrm{N}_{2} \\
\text { environment. } \\
\text { Nickel based alloys are } \\
\text { typically immune to nitridation, } \\
\text { but can occur in the stainless } \\
\text { steel alloys. }\end{array}$ \\
\hline
\end{tabular}

3. Downtime Corrosion

\begin{tabular}{|l|l|l|l|}
\hline $\begin{array}{c}\text { Corrosion } \\
\text { Type }\end{array}$ & \multicolumn{1}{|c|}{ Definition } & \multicolumn{1}{c|}{ Manifestation } & \multicolumn{1}{c|}{ Case Potential } \\
\hline $\begin{array}{l}\text { Downtime } \\
\text { corrosion }\end{array}$ & $\begin{array}{l}\text { Corrosion occurring } \\
\text { during the times when } \\
\text { the system is not } \\
\text { operating, but at } \\
\text { ambient conditions }\end{array}$ & $\begin{array}{l}\text { Any of the aqueous corrosion } \\
\text { mechanisms, particularly } \\
\text { intergranular corrosion that can } \\
\text { occur to a greater extent due to } \\
\text { diminished resistance of the } \\
\text { materials from the high- } \\
\text { temperature exposures. }\end{array}$ & $\begin{array}{l}\text { The feed materials have significant } \\
\text { salts that are hygroscopic in nature } \\
\text { and can absorb water at various } \\
\text { relative humidities per their specific } \\
\text { deliquescence points, and lead to } \\
\text { aqueous corrosion }\end{array}$ \\
\hline
\end{tabular}




\section{Acid Corrosion}

\begin{tabular}{|l|l|l|l|}
\hline \multicolumn{1}{|c|}{$\begin{array}{c}\text { Corrosion } \\
\text { Type }\end{array}$} & \multicolumn{1}{|c|}{ Definition } & \multicolumn{1}{c|}{ Manifestation } & \multicolumn{1}{c|}{ Case Potential } \\
\hline $\begin{array}{l}\text { Acid } \\
\text { Corrosion }\end{array}$ & $\begin{array}{l}\text { Corrosion due to acid } \\
\text { formation when } \\
\text { resident vapor species } \\
\text { react with condensed } \\
\text { water, e.g. HCl. }\end{array}$ & $\begin{array}{l}\text { Any of the aqueous corrosion } \\
\text { mechanisms, particularly } \\
\text { intergranular corrosion that can } \\
\text { occur to diminished resistance of } \\
\text { the materials from the high- } \\
\text { temperature exposures }\end{array}$ & $\begin{array}{l}\text { The feed materials have significant } \\
\text { salts that can volatilize and react } \\
\text { with ambient humidity to create } \\
\text { acids, specifically at ambient } \\
\text { downtime conditions. }\end{array}$ \\
$\begin{array}{l}\text { There is also a potential for acid } \\
\text { corrosion when condensed water } \\
\text { during processing reacts with } \\
\text { volatilized species. }\end{array}$ \\
\hline
\end{tabular}

5. Erosion Corrosion

\begin{tabular}{|l|l|l|l|}
\hline $\begin{array}{c}\text { Corrosion } \\
\text { Type }\end{array}$ & \multicolumn{1}{|c|}{ Definition } & \multicolumn{1}{c|}{ Manifestation } & \multicolumn{1}{c|}{ Case Potential } \\
\hline Erosion & $\begin{array}{l}\text { Corrosion due to due } \\
\text { to wear or abrasive } \\
\text { contributions to the } \\
\text { corrosion mechanisms. }\end{array}$ & $\begin{array}{l}\text { Assists the corrosion } \\
\text { mechanisms and can be } \\
\text { recognized by waves, valleys or } \\
\text { a directional pattern. The } \\
\text { erosion primarily leads to the } \\
\text { breakdown of the protective } \\
\text { oxide layer. }\end{array}$ & $\begin{array}{l}\text { The erosion corrosion can be } \\
\text { induced through wear by the gas } \\
\text { flow or the entrainment of feed } \\
\text { particles/spalled corrosion products } \\
\text { in the stream leading to abrasion. }\end{array}$ \\
\hline
\end{tabular}

All of these corrosion mechanisms can be enhanced by the synergistic effects of mechanical factors including thermal stresses (e.g. thermal fatigue), potential dynamic loading, and simple stresses from the process itself.

\section{RESULTS}

\subsection{Corrosion Analysis}

The coupons were initially visually inspected and photographed. Deposits were analyzed by two means. The deposits that could be easily removed by light scraping were ground and placed on a glass and analyzed with x-ray diffraction (XRD). Coupons having tenaciously bound deposits were placed directly on the XRD system for analysis. Hence, some of the XRD spectra may show evidence of base metal constituents, e.g. nickel and chromium. The coupons were then sectioned, polished, and microscopically inspected, and photographed at low and high magnifications. The coupon thicknesses were measured on the as-polished metallographic specimen using a measuring microscopy. The analysis of the coupons and deposits were done for each coupon and are presented in the following sections.

\subsubsection{Coupons Exposed to DMR Bed}

The DMR, operating in a chemically reducing mode, evaporates liquids, partially cracks and volatilizes organics, converts nitrates to nitrogen gas, and converts nonvolatile constituents of the feed into a sodium carbonate-based, granular solid product. The reducing condition in the DMR is created by the injection of fluidizing steam, charcoal, and a small amount of oxygen to react with the charcoal to produce energy in the bed. The coupons in the DMR bed were mounted vertically to a horizontal bar, with the short edge (w/o hole) downward in the upward gas flow, as shown in Figure 1. The nominal average temperature was $640^{\circ} \mathrm{C} \pm 40^{\circ} \mathrm{C}$. 


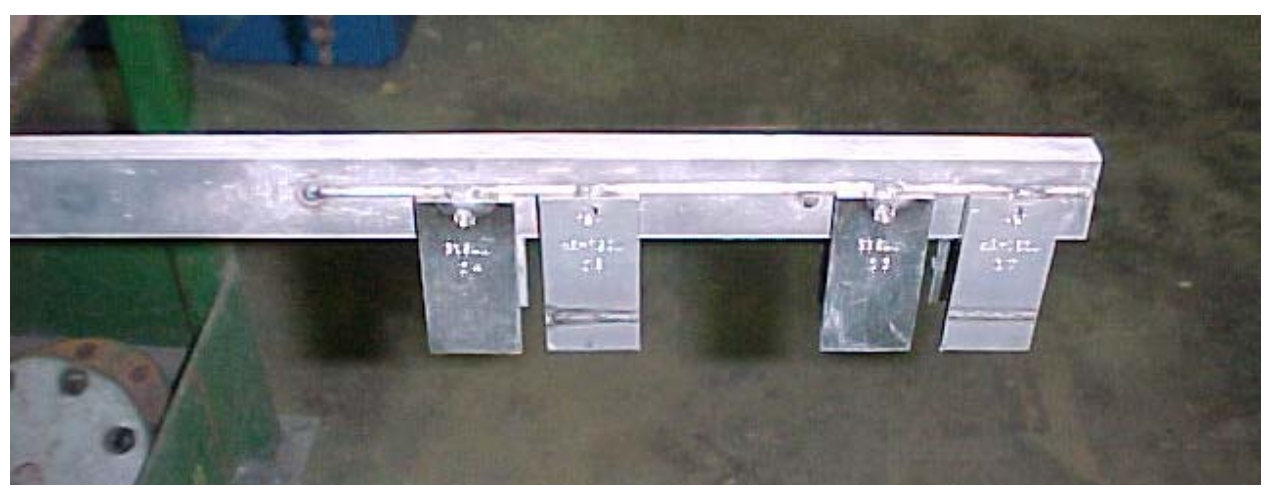

Figure 1: Coupons Exposed to DMR Bed

The pictures of the coupons exposed to the DMR bed are shown in Table 5. The coupons showed pervasive oxidation with process deposits as well as oxides from the coupons. The primary deposits were sulfates and sodium alumino-silicates.

Table 5: Coupons Exposed to DMR in Bed

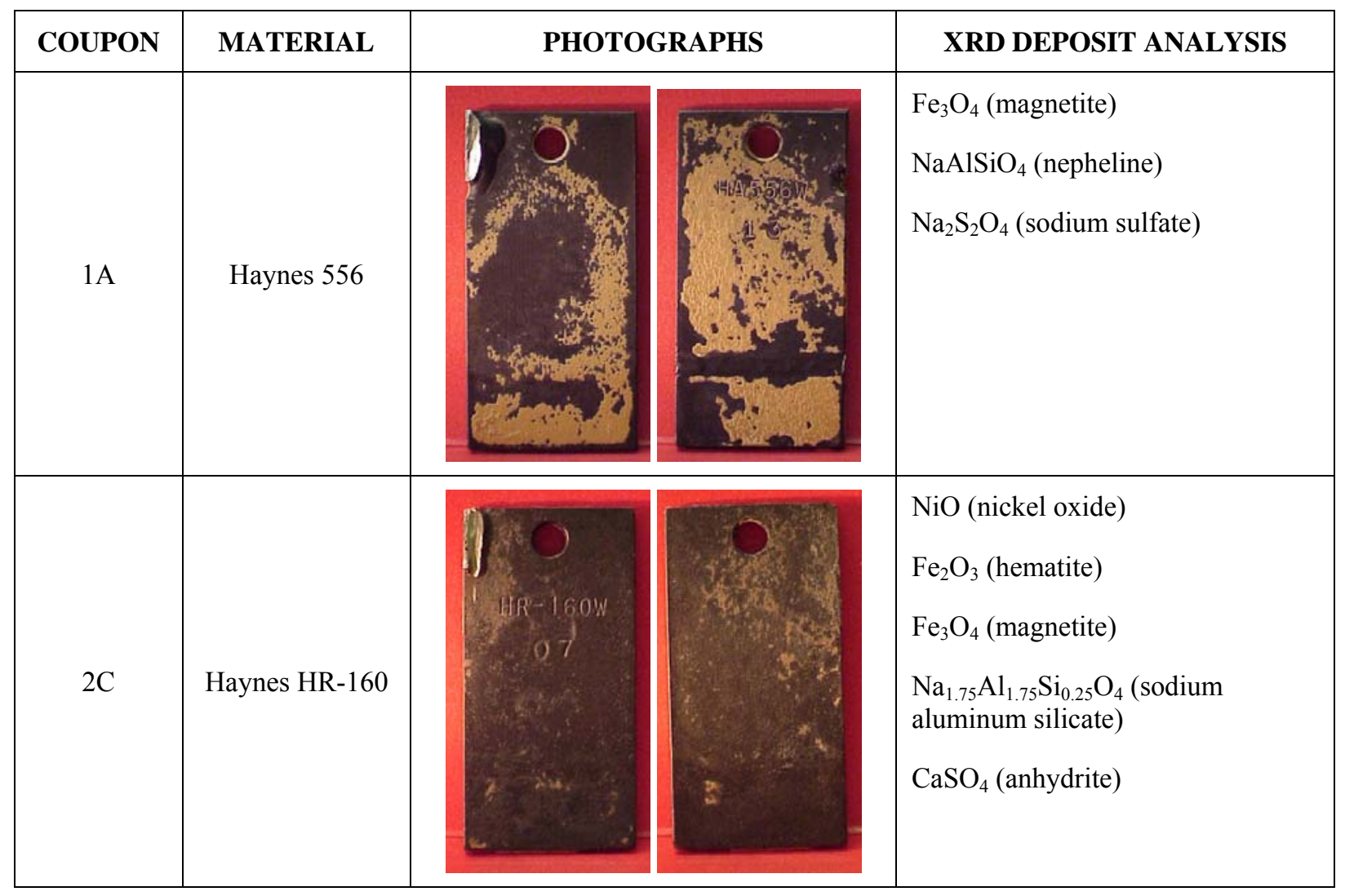




\begin{tabular}{|c|c|c|c|}
\hline COUPON & MATERIAL & PHOTOGRAPHS & XRD DEPOSIT ANALYSIS \\
\hline $3 \mathrm{E}$ & Haynes 230 & & $\begin{array}{l}\mathrm{NiO} \text { (nickel oxide) } \\
\mathrm{Fe}_{2} \mathrm{O}_{3} \text { (hematite) } \\
\mathrm{Fe}_{3} \mathrm{O}_{4} \text { (magnetite) } \\
\mathrm{CaSO}_{4} \text { (anhydrite) }\end{array}$ \\
\hline $4 \mathrm{G}$ & 316L SS & & $\begin{array}{l}\mathrm{Fe}_{2} \mathrm{O}_{3} \text { (hematite) } \\
\mathrm{Fe}_{3} \mathrm{O}_{4} \text { (magnetite) } \\
\mathrm{Al}_{2} \mathrm{O}_{3} \text { (corundum) } \\
\mathrm{Na}_{6} \mathrm{Ca}_{1.5} \mathrm{Al}_{6} \mathrm{Si}_{6} \mathrm{O}_{24}\left(\mathrm{CO}_{3}\right)_{1.6} \\
\text { (cancrinite) } \\
\mathrm{NaAlSiO}_{4} \text { (nepheline) }\end{array}$ \\
\hline
\end{tabular}

The micrographs of the coupons exposed to the DMR bed are shown in Figure 2 - 5. The Haynes 556 and 230 alloys appear to have a relatively straight corrosion front, while the HR-160 alloy exhibited intergranular attack. The Haynes 230 alloys appeared to have diffusion related effects as the grain boundaries were explicitly visible.
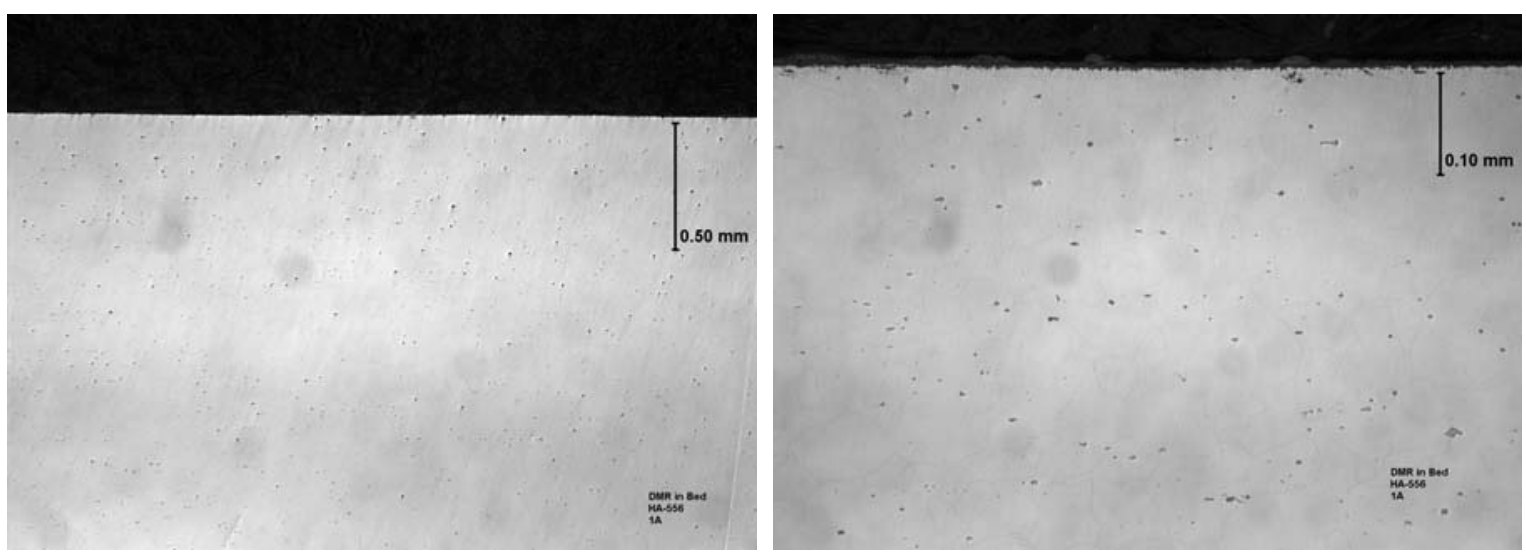

Figure 2: Metallographic Cross Section of Coupon 1A - Haynes 556 Alloy Exposed to DMR Bed 

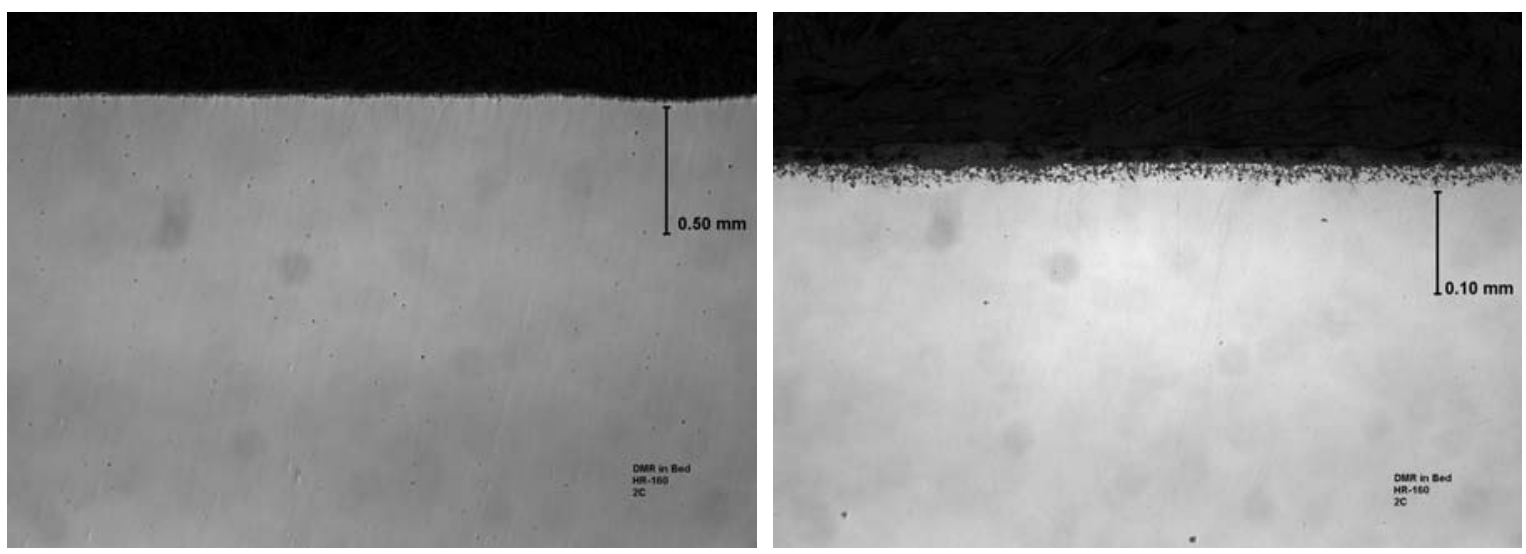

Figure 3: Metallographic Cross Section of Coupon 2C - Haynes HR-160 Alloy Exposed to DMR Bed
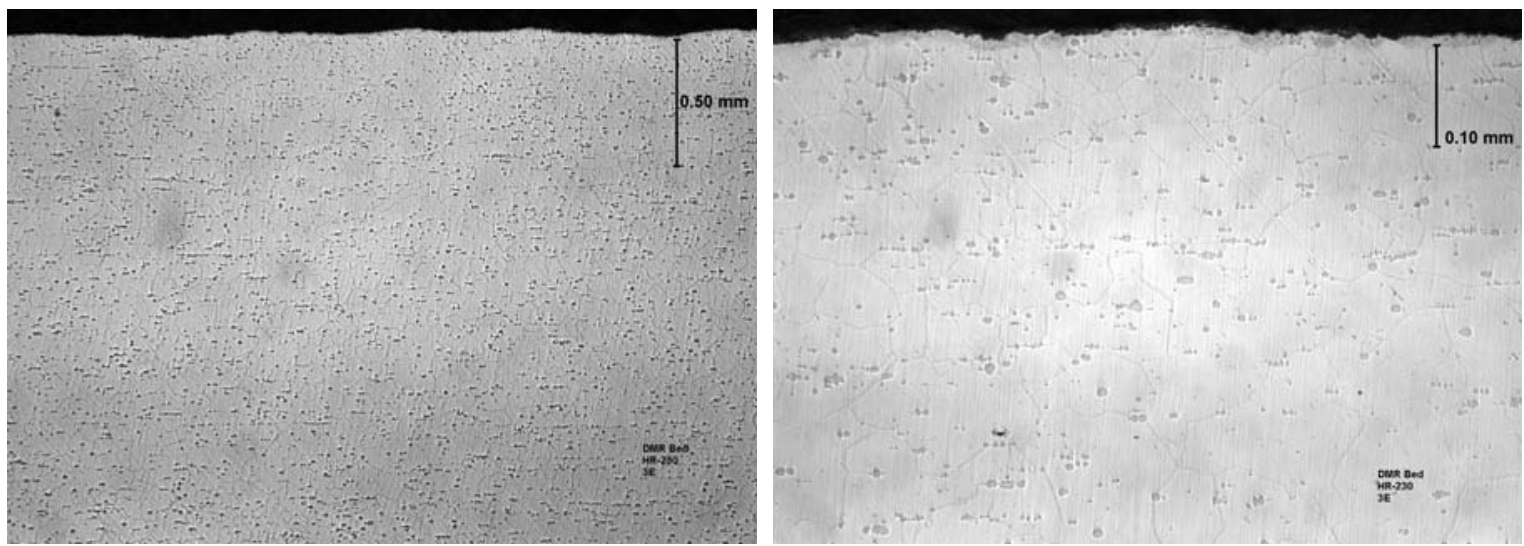

Figure 4: Metallographic Cross Section of Coupon 3E - Haynes 230 Alloy Exposed to DMR Bed

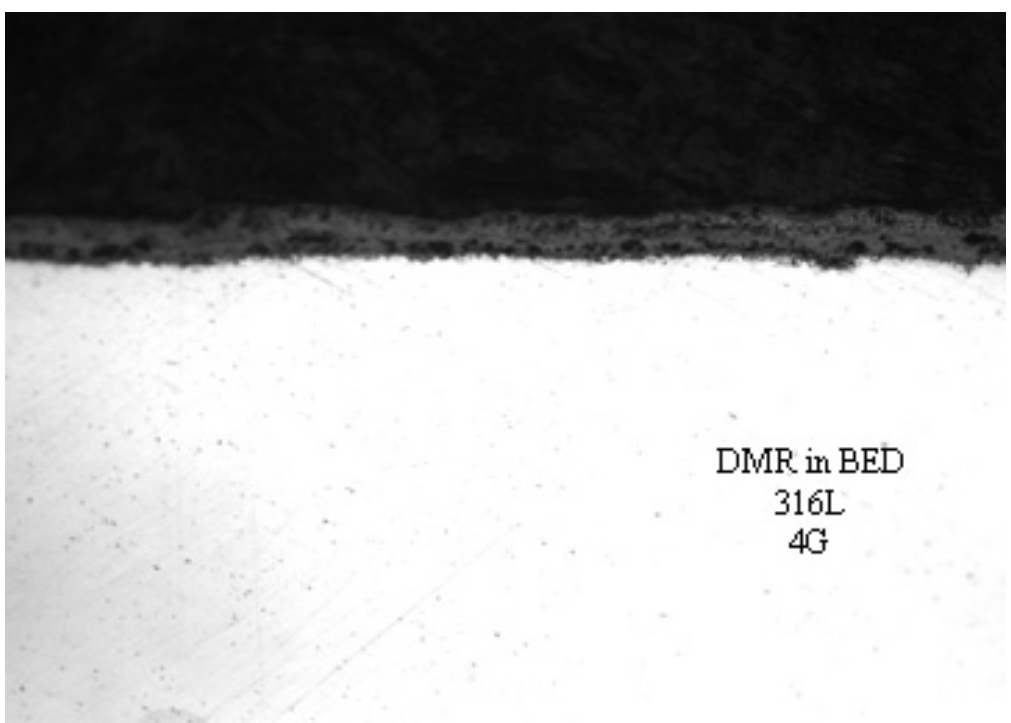

Figure 5: Metallographic Cross Section of Coupon 4G - 316L Exposed to DMR Bed

The Haynes 556 appeared to have a uniform corrosion front with a continuous protective oxide scale. The Haynes 230 showed evidence of non-uniform attack, i.e. pitting and a slightly thicker oxide scale. The Haynes HR-160 exhibited uniform and shallow intergranular attack (IGA). The 316L stainless steel exhibited a thick oxide scale. 
The coupons exposed to the DMR are possibly subject to ash-type corrosion due to the mixed waste form, sulfidation during the high temperature operation in a reducing environment, and any modes of the down-time corrosion. Due to the complex nature of the waste, any of these corrosion mechanisms are expected to be exacerbated by the influence of the halogens.

Sulfidation is most aggressive when low-melting point metal-sulfide eutectics form providing rapid diffusion paths.

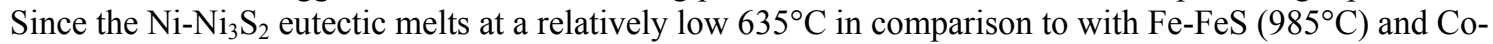
$\mathrm{Co}_{4} \mathrm{~S}_{3}\left(880^{\circ} \mathrm{C}\right)$, the resistance to sulfidation decreases with increasing nickel content.[6] However, the HR-160 alloy (with the highest nickel content) was developed solely to resist sulfidation, through the addition of silicon and chromium to provide a protective oxide layer to sulfidation.[7] However, this is provided that the temperature is sufficient to form the protective silicon oxide layer. In this case, the Haynes 556 alloy appears to have performed better than the other alloys.

Scanning electron microscopy (SEM) and x-ray dispersive spectroscopy (EDX) was completed in order to determine potential corrosion mechanisms. The micrographs and the respective EDX analysis are shown in Figure $6-8$. The results indicated that all alloys have a sodium aluminosilicate layer on the surface (in concurrence with the XRD results) and sulfate deposits on the surface suggesting fuel-ash type corrosion as the primary mechanism of corrosion. It is suspected that the deposits (particularly silicates and sulfates) play a role in the breakdown of the oxide scale and change conditions such that reformation of the oxide scale is difficult. These corrosion mechanisms are further exacerbated by the presence of impurities such as chlorides. In addition, the formation of sulfides within the matrix indicates that sulfidation is active within the matrix, which has been known to play an important role in the corrosion of alloys in low-level radioactive waste incinerators.[8] As such, SEM and EDX were used to determine the formation of the sulfides within the matrix.

In the HA-556 alloy, the underlying oxide is primarily iron oxide, and there was no evidence of sulfide phase forming within the matrix. The HR-160 alloy had an oxide layer of a combination of chromium, cobalt, and nickel. However, there was evidence of chromium-rich sulfide formation within the matrix. The HA-230 alloy had an oxide layer of a combination of chromium, and nickel. However, there was evidence of chromium-rich sulfide formation within the matrix. The SEM/EDX analyses confirmed the formation of sulfide rich eutectics in the HR-160 and the HA-230 alloys, whereas the HA-556 alloys did not. As such, the HA-556 alloys is expected to have performed better than the other alloys in this application.

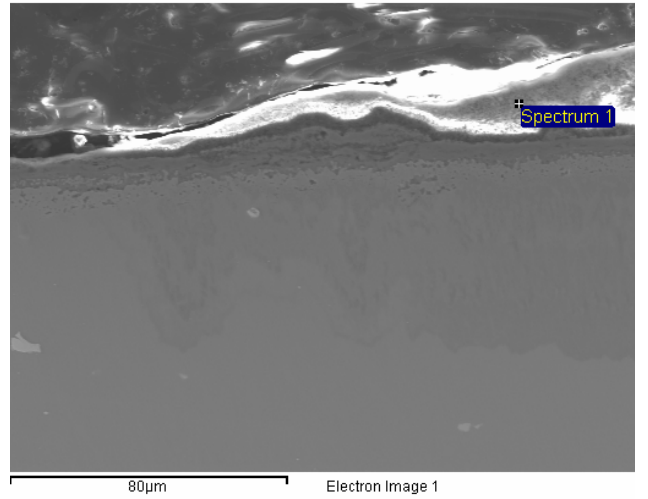

\begin{tabular}{c|cc}
\hline Element & Weight\% & Atomic\% \\
C K & 32.17 & 44.04 \\
O K & 37.61 & 38.65 \\
Na K & 6.25 & 4.47 \\
Al K & 8.91 & 5.43 \\
Si K & 7.04 & 4.12 \\
\hline
\end{tabular}

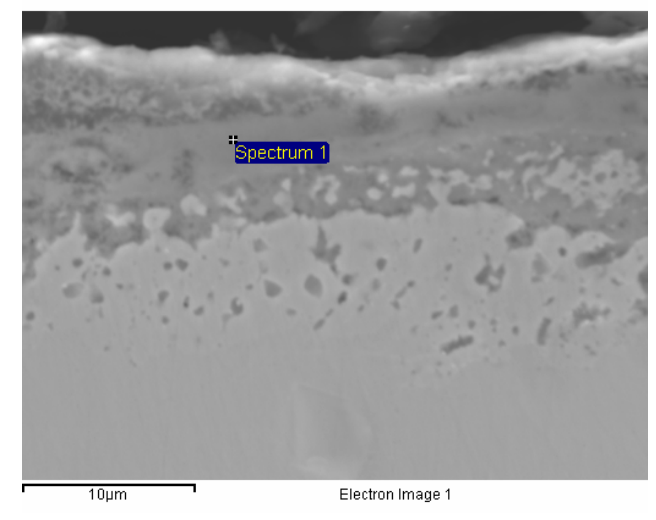

\begin{tabular}{c|cc}
\hline Element & Weight\% & Atomic\% \\
C K & 1.73 & 4.17 \\
O K & 31.55 & 56.93 \\
Cr K & 10.07 & 5.59 \\
Fe K & 41.34 & 21.37 \\
\hline
\end{tabular}

Figure 6: SEM/EDX of HA-556 Alloy Exposed to DMR Bed Indicating Ash-Type Deposit and Underlying Iron Oxide. 


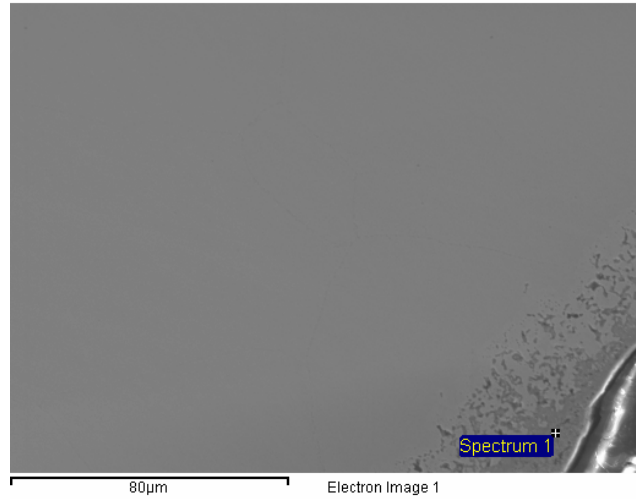

\begin{tabular}{c|cc}
\hline Element & Weight\% & Atomic\% \\
C K & 9.07 & 20.32 \\
O K & 28.04 & 47.19 \\
Cr K & 13.58 & 7.03 \\
Co K & 27.59 & 12.61 \\
Ni K & 11.18 & 5.13 \\
\hline
\end{tabular}

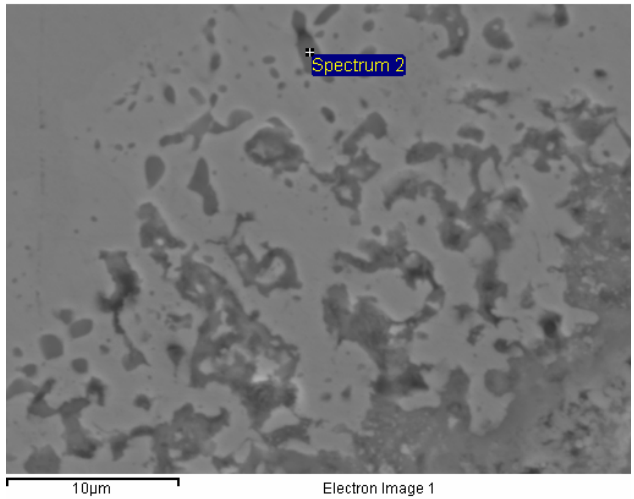

\begin{tabular}{l|ll}
\hline Element & Weight\% & Atomic\% \\
C K & 2.79 & 9.80 \\
S K & 26.42 & 34.79 \\
Cr K & 31.00 & 25.17 \\
Co K & 15.80 & 11.32 \\
Ni K & 22.40 & 16.11 \\
\hline
\end{tabular}

Figure 7: SEM/EDX of HR-160 Alloy Exposed to DMR Bed Indicating Ash-Type Deposit and Sulfide Formation Within Matrix

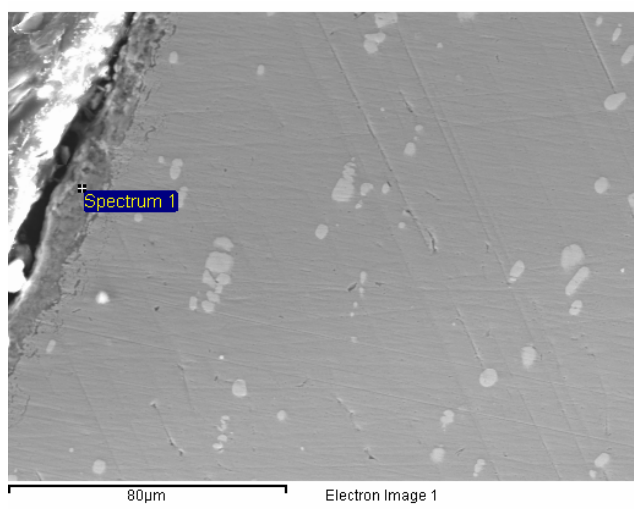

\begin{tabular}{c|cc}
\hline Element & Weight\% & Atomic\% \\
O K & 17.92 & 42.61 \\
Cr K & 40.04 & 29.29 \\
Ni K & 28.93 & 18.74 \\
\hline
\end{tabular}

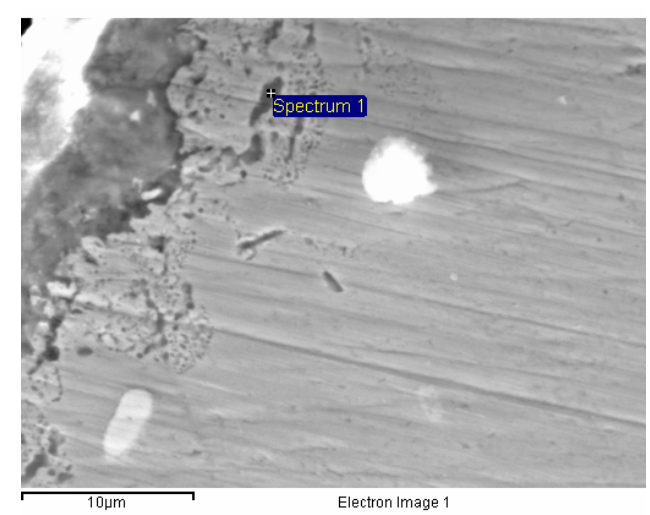

\begin{tabular}{c|cc}
\hline Element & Weight\% & Atomic\% \\
C K & 4.54 & 15.90 \\
S K & 24.57 & 32.25 \\
Cr K & 34.38 & 27.82 \\
Ni K & 33.32 & 23.89 \\
\hline
\end{tabular}

Figure 8: SEM/EDX of HA-230 Alloy Exposed to DMR Bed Indicating Ash-Type Deposit and Sulfide Formation Within Matrix 


\subsubsection{Coupons Exposed to DMR Freeboard}

The coupons exposed to the DMR freeboard are expected to be exposed to the volatilized constituents from the DMR bed. The availability of the oxygen and process deposits in the freeboard may lead to higher corrosion rates than the coupons exposed to the DMR bed. The coupons exposed in the DMR freeboard were mounted vertically from a wire/rod in close proximity to each other on the large surface area front, with the short edge (w/o hole) down in the upward gas flow as shown in Figure 9. The coupons hung on the "outside" of the rack are expected to have the most corrosion since they have the most exposure to the conditions. It is possible that the others were somewhat protected due to the proximity of the coupons, particularly on the large surface areas. The nominal average temperature was $610^{\circ} \mathrm{C} \pm 40^{\circ} \mathrm{C}$.

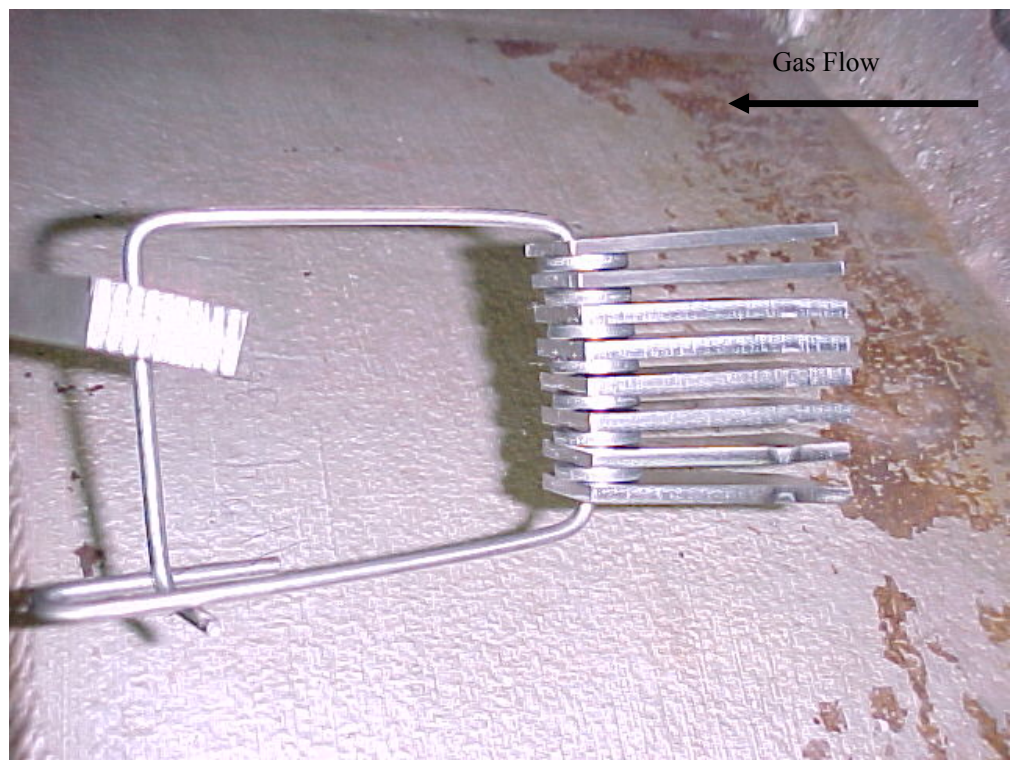

Figure 9: Coupons Exposed to DMR Freeboard

The photographs of the coupons are shown in Table 6. There was evidence of significant process deposits on the coupons.

Table 6: Coupons Exposed to DMR Freeboard

\begin{tabular}{|c|c|c|c|}
\hline COUPON & MATERIAL & PHOTOGRAPHS & XRD DEPOSIT ANALYSIS \\
\hline $1 \mathrm{D}$ & Haynes 556 & & $\begin{array}{l}\mathrm{Na}_{6} \mathrm{Ca}_{1.5} \mathrm{Al}_{6} \mathrm{Si}_{6} \mathrm{O}_{24}\left(\mathrm{CO}_{3}\right)_{1.6} \\
\text { cancrinite) } \\
\mathrm{Na}_{1.75} \mathrm{Al}_{1.75} \mathrm{Si}_{0.25} \mathrm{O}_{4} \text { (sodium } \\
\text { aluminum silicate) } \\
\mathrm{Fe}_{3} \mathrm{O}_{4} \text { (magnetite) } \\
\mathrm{Na}_{2} \mathrm{~S}_{2} \mathrm{O}_{4} \text { (sodium sulfate) } \\
\mathrm{CaF}_{2} \text { (calcium fluorite) }\end{array}$ \\
\hline
\end{tabular}




\begin{tabular}{|c|c|c|c|}
\hline COUPON & MATERIAL & PHOTOGRAPHS & XRD DEPOSIT ANALYSIS \\
\hline $2 \mathrm{~F}$ & Haynes HR-160 & & $\begin{array}{l}\mathrm{NaCl} \text { (halite) } \\
\mathrm{Na}_{2} \mathrm{~S}_{2} \mathrm{O}_{4} \text { (sodium sulfate) } \\
\mathrm{SiO}_{2} \text { (quartz) } \\
\mathrm{NiO} \text { (nickel oxide) } \\
\mathrm{CoCr}_{2} \mathrm{O}_{4} \text { (cochromite) } \\
\mathrm{Na}_{6} \mathrm{Ca}_{1.5} \mathrm{Al}_{6} \mathrm{Si}_{6} \mathrm{O}_{24}\left(\mathrm{CO}_{3}\right)_{1.6} \\
(\text { cancrinite) } \\
\mathrm{K}_{2} \mathrm{SO}_{4} \text { (arcanite) }\end{array}$ \\
\hline $3 \mathrm{H}$ & Haynes 230 & & $\begin{array}{l}\mathrm{NiO} \text { (nickel oxide) } \\
\mathrm{Fe}_{2} \mathrm{O}_{3} \text { (hematite) } \\
\mathrm{Fe}_{3} \mathrm{O}_{4} \text { (magnetite) } \\
\mathrm{CaSO}_{4} \text { (anhydrite) }\end{array}$ \\
\hline 4B & 316L SS & & $\begin{array}{l}\mathrm{Fe}_{2} \mathrm{O}_{3} \text { (hematite) } \\
\mathrm{Fe}_{3} \mathrm{O}_{4} \text { (magnetite) } \\
\mathrm{Al}_{2} \mathrm{O}_{3} \text { (corundum) } \\
\mathrm{Na}_{6} \mathrm{Ca}_{1.5} \mathrm{Al}_{6} \mathrm{Si}_{6} \mathrm{O}_{24}\left(\mathrm{CO}_{3}\right)_{1.6} \\
(\text { cancrinite) } \\
\mathrm{NaAlSiO}_{4} \text { (nepheline) }\end{array}$ \\
\hline
\end{tabular}

The micrographs of the coupons exposed to the DMR freeboard are shown in Figure 10 - 13. The Haynes 556 and 230 alloys appear to have a relatively uniform corrosion front, while the HR-160 alloy exhibited intergranular attack on the surface. The $316 \mathrm{~L}$ stainless steel showed an extensive oxide layer and IGA. 

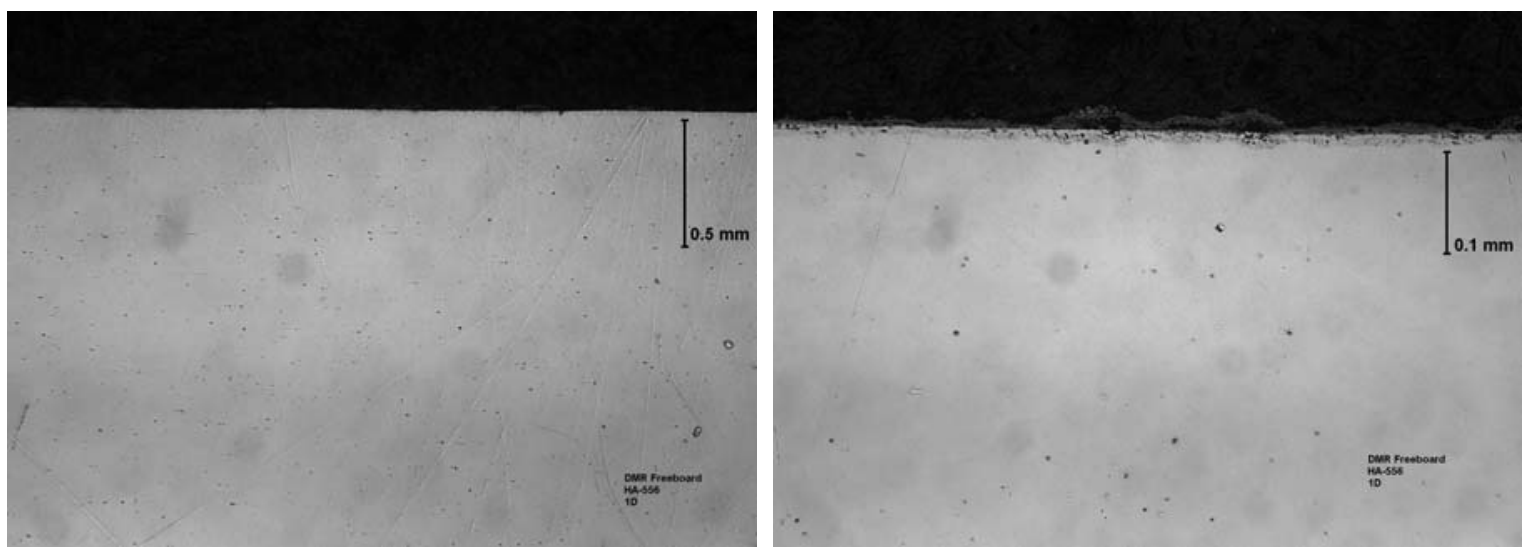

Figure 10: Metallographic Cross Section of Coupon 1D - Haynes 556 Alloy Exposed to DMR Freeboard
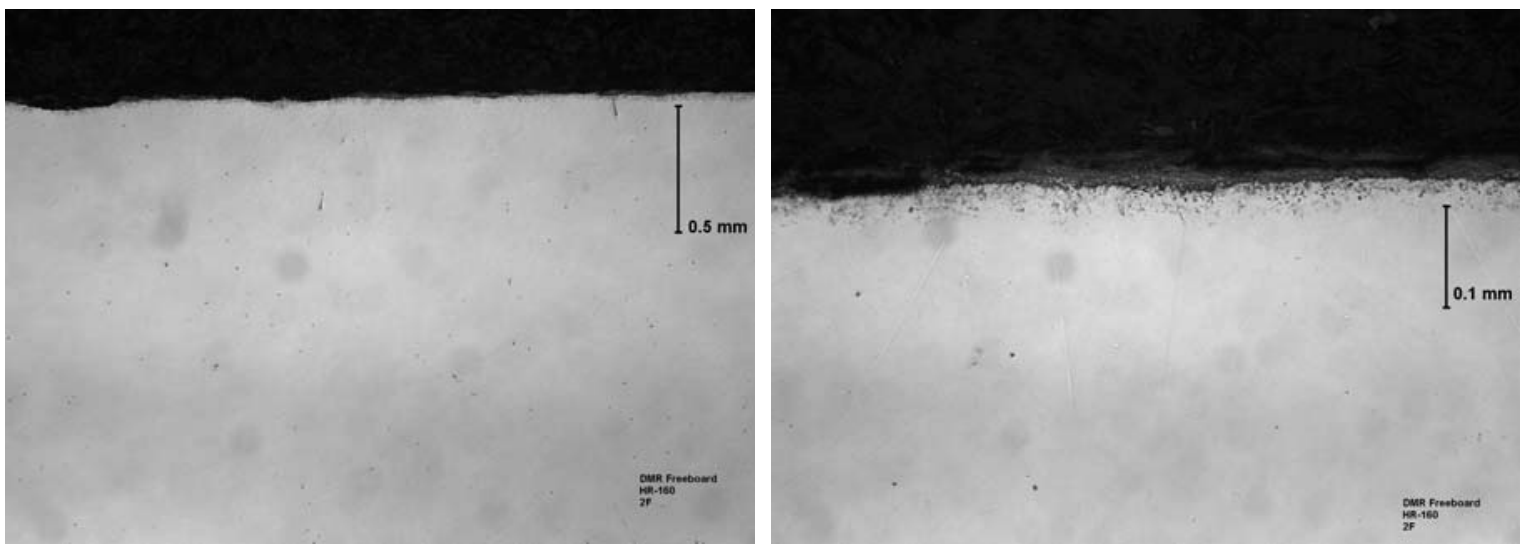

Figure 11: Metallographic Cross Section of Coupon 2F - Haynes HR-160 Alloy Exposed to DMR Freeboard
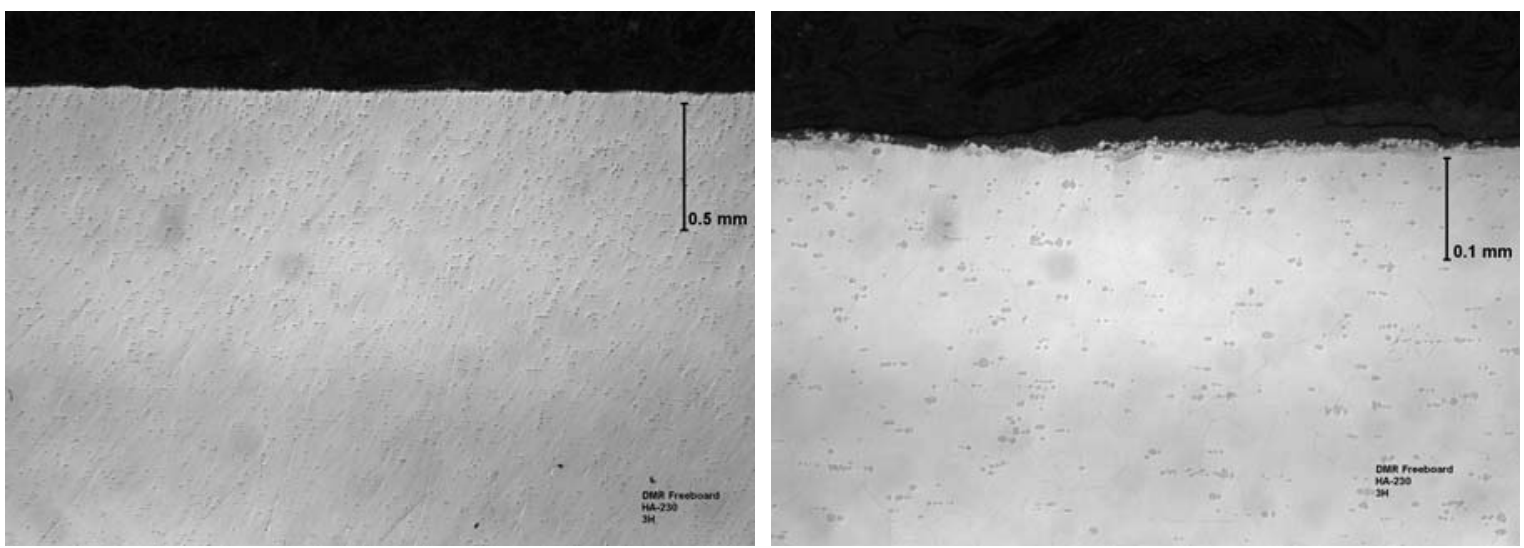

Figure 12: Metallographic Cross Section of Coupon 3H - Haynes 230 Alloy Exposed to DMR Freeboard 

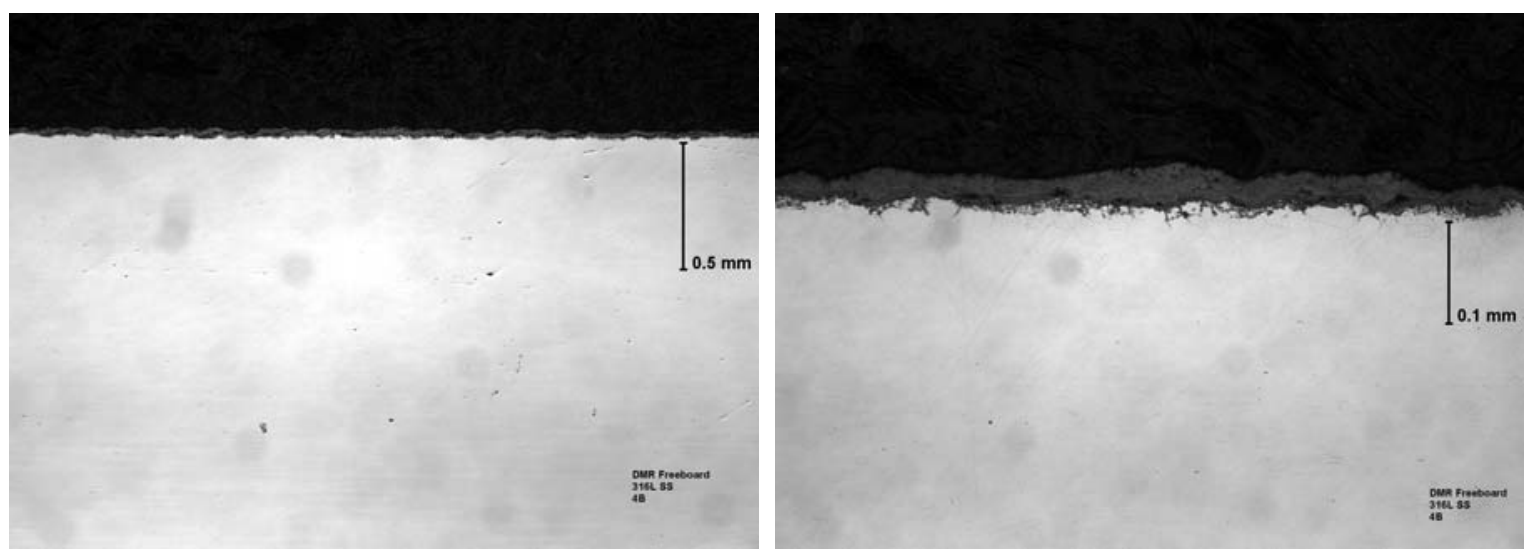

Figure 13: Metallographic Cross Section of Coupon 4B - 316L SS Exposed to DMR Freeboard

The coupons exposed to the DMR freeboard were expected to be subject to the same corrosion as in the DMR bed. Once again, SEM/EDX analysis, shown in Figure $14-16$ was completed to determine the presence of sulfides in the matrix. As with the coupons exposed to the DMR bed, the HA-556 alloys did not exhibit the formation of the sulfides, while the HR-160 and the HA-230 alloys exhibited sulfide formation. As with the coupons exposed to the DMR bed, the HA-556is expected to perform better than the alloys given the formation of the sulfides.
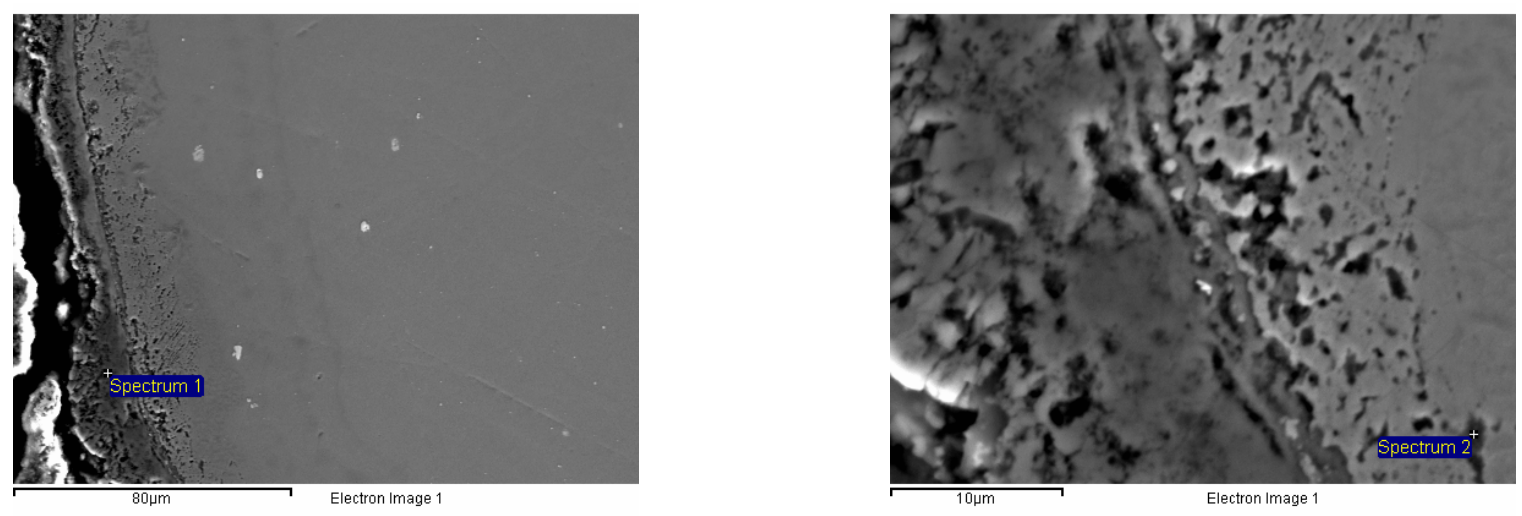

\begin{tabular}{c|cc}
\hline Element & Weight\% & Atomic\% \\
C K & 1.88 & 4.28 \\
O K & 36.31 & 62.17 \\
Cr K & 45.95 & 24.21 \\
Fe K & 9.34 & 4.58 \\
\hline
\end{tabular}

\begin{tabular}{c|cc}
\hline Element & Weight\% & Atomic\% \\
O K & 20.46 & 46.27 \\
Fe K & 10.18 & 6.59 \\
Cr K & 32.43 & 22.57 \\
Co K & 11.97 & 7.35 \\
Ni K & 11.68 & 7.20 \\
\hline
\end{tabular}

Figure 14: SEM/EDX of HA-556 Alloy Exposed to DMR Bed Indicating Ash-Type Deposit and Underlying Oxide. 

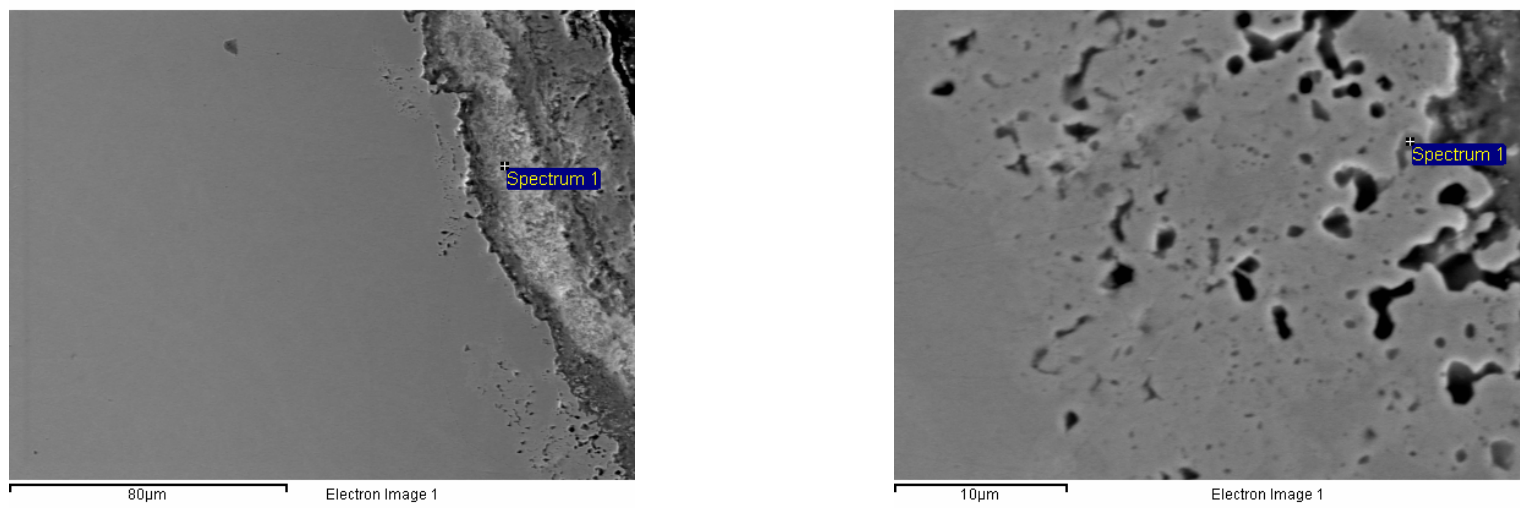

\begin{tabular}{c|cc}
\hline Element & Weight\% & Atomic\% \\
O K & 28.72 & 56.44 \\
Cr K & 20.24 & 12.24 \\
Co K & 15.45 & 8.24 \\
Ni K & 28.13 & 15.07 \\
\hline
\end{tabular}

\begin{tabular}{c|cc}
\hline Element & Weight\% & Atomic\% \\
S K & 11.23 & 18.48 \\
Cr K & 12.53 & 12.71 \\
Co K & 26.54 & 23.76 \\
Ni K & 49.33 & 44.32 \\
\hline
\end{tabular}

Figure 15: SEM/EDX of HR-160 Alloy Exposed to DMR Bed Indicating Ash-Type Deposit and Sulfide Formation Within Matrix

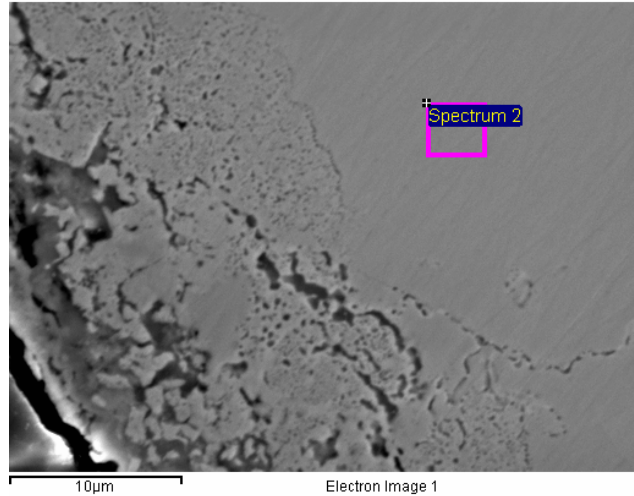

\begin{tabular}{c|cc}
\hline Element & Weight\% & Atomic\% \\
O K & 0.57 & 2.25 \\
Cr K & 22.94 & 27.85 \\
Ni K & 57.02 & 61.31 \\
W K & 15.68 & 5.38 \\
\hline
\end{tabular}

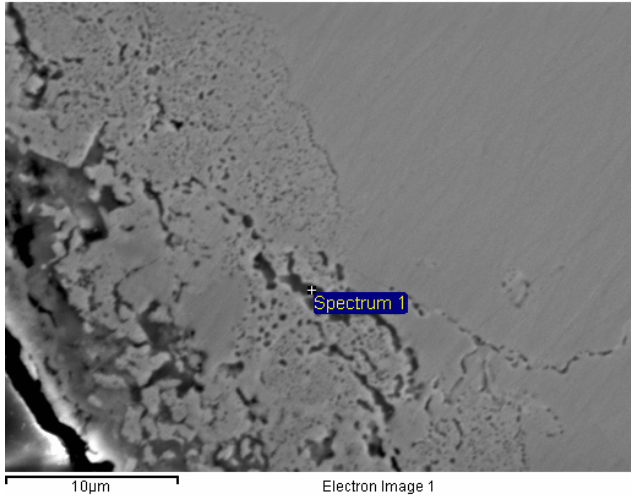

\begin{tabular}{c|cc}
\hline Element & Weight\% & Atomic\% \\
S K & 28.30 & 41.88 \\
Cr K & 38.09 & 34.76 \\
Ni K & 30.35 & 24.53 \\
\hline
\end{tabular}

Figure 16: SEM/EDX of HA-230 Alloy Exposed to DMR Bed Indicating Ash-Type Deposit and Sulfide Formation Within Matrix

\subsubsection{Coupons Exposed to HTF Dirty Side}

The process gas from the DMR, consisting mostly of steam, nitrogen, carbon dioxide, and hydrogen, with small amounts of carbon monoxide, $\mathrm{NO}_{\mathrm{x}}$, short-chained organics, and acidic gases, is filtered through the High 
Temperature Filter (HTF). This filter removes the finely divided product solids and charcoal fines that elutriate out of the DMR with the process gas stream. The coupons were exposed to the "dirty side" of the HTF, or just prior to the filter medium in the process stream. The coupons were mounted vertically from a wire/rod in close proximity to each other on the large surface area front, with short edge (w/o hole) in downward gas flow, as shown in Figure 17. The nominal temperature in this region of the process was nominally $520^{\circ} \mathrm{C} \pm 40^{\circ} \mathrm{C}$.

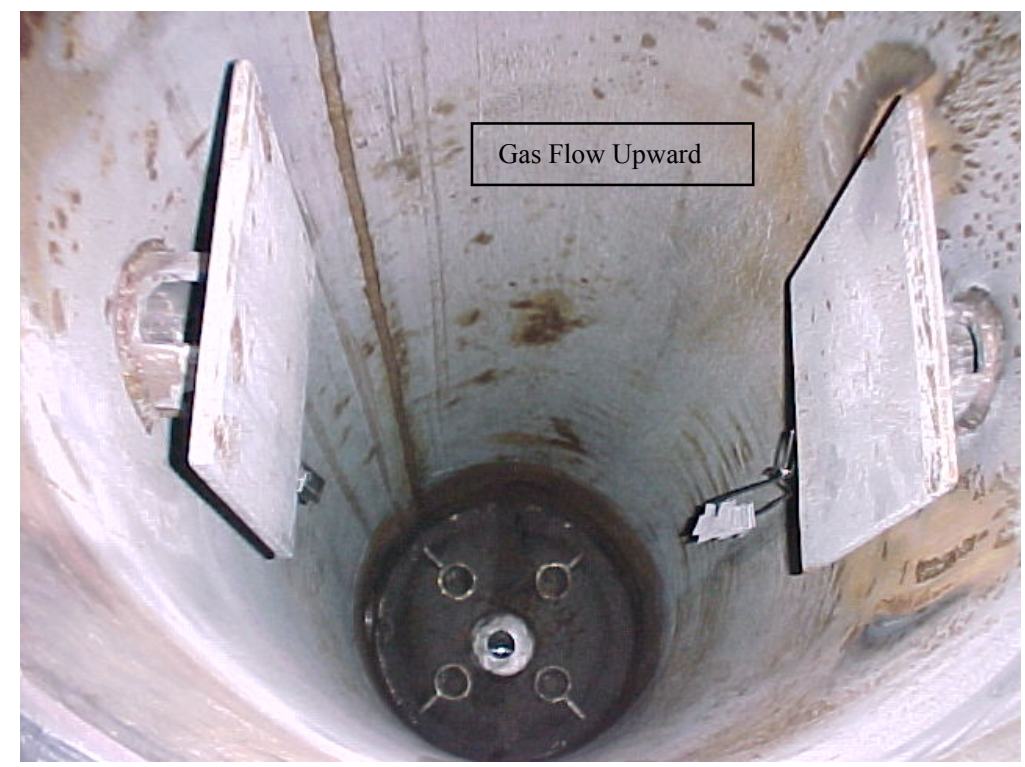

Figure 17: Coupons Exposed to the HTF Dirty Side

Photographs of the coupons exposed to the HTF dirty side are shown in Table 7.

Table 7: Coupons Exposed to the HTF Dirty Side

\begin{tabular}{|c|c|c|c|}
\hline COUPON & MATERIAL & PHOTOGRAPHS & XRD DEPOSIT ANALYSIS \\
\hline $1 \mathrm{E}$ & Haynes 556 & & $\begin{array}{l}\mathrm{NiO} \text { (nickel oxide) } \\
\mathrm{Na}_{6} \mathrm{CO}_{3}\left(\mathrm{SO}_{4}\right)_{2} \text { (sodium carbonate } \\
\text { sulfate) } \\
\mathrm{Fe}_{3} \mathrm{O}_{4} \text { (magnetite) } \\
\mathrm{Na}_{1.75} \mathrm{Al}_{1.75} \mathrm{Si}_{0.25} \mathrm{O}_{4} \text { (sodium } \\
\text { aluminum silicate) } \\
\mathrm{Na}_{6} \mathrm{Ca}_{1.5} \mathrm{Al}_{6} \mathrm{Si}_{6} \mathrm{O}_{24}\left(\mathrm{CO}_{3}\right)_{1.6} \\
\text { (cancrinite) }\end{array}$ \\
\hline
\end{tabular}




\begin{tabular}{|c|c|c|c|}
\hline COUPON & MATERIAL & PHOTOGRAPHS & XRD DEPOSIT ANALYSIS \\
\hline $2 \mathrm{G}$ & Haynes HR-160 & & $\begin{array}{l}\mathrm{Al}_{2} \mathrm{O}_{3} \text { (corundum) } \\
\mathrm{Na}_{2} \mathrm{Al}_{2} \mathrm{O}_{34} \text { (sodium aluminum } \\
\text { oxide) } \\
\mathrm{CaF}_{2} \text { (calcium fluorite) }\end{array}$ \\
\hline $3 \mathrm{~A}$ & Haynes 230 & & $\begin{array}{l}\mathrm{NiO} \text { (nickel oxide) } \\
\mathrm{CaWO}_{4} \text { (scheelite) } \\
\mathrm{Fe}_{2} \mathrm{O}_{3} \text { (hematite) } \\
\mathrm{Na}_{6} \mathrm{CO}_{3}\left(\mathrm{SO}_{4}\right)_{2} \text { (sodium carbonate } \\
\text { sulfate) }\end{array}$ \\
\hline $4 \mathrm{C}$ & 316L SS & & $\begin{array}{l}\mathrm{Fe}_{2} \mathrm{O}_{3} \text { (hematite) } \\
\mathrm{Fe}_{3} \mathrm{O}_{4} \text { (magnetite) } \\
\mathrm{Al}_{2} \mathrm{O}_{3} \text { (corundum) } \\
\mathrm{NaAl}_{11} \mathrm{O}_{17} \text { (diayudaoite) } \\
\mathrm{CaF}_{2} \text { (calcium fluorite) } \\
\mathrm{NiFe}(\text { tetrataenite) } \\
\mathrm{Ca}\left(\mathrm{SO}_{4}\right)_{2} \text { (anhydrite) }\end{array}$ \\
\hline
\end{tabular}

The micrographs of the coupons exposed to the dirty side of the HTF are shown in Figure 18 - 21. The Haynes 556 and HR-160 alloys exhibited relatively uniform corrosion fronts without evidence of IGA. The HR-160 and 230 alloys showed evidence of pitting attack. 


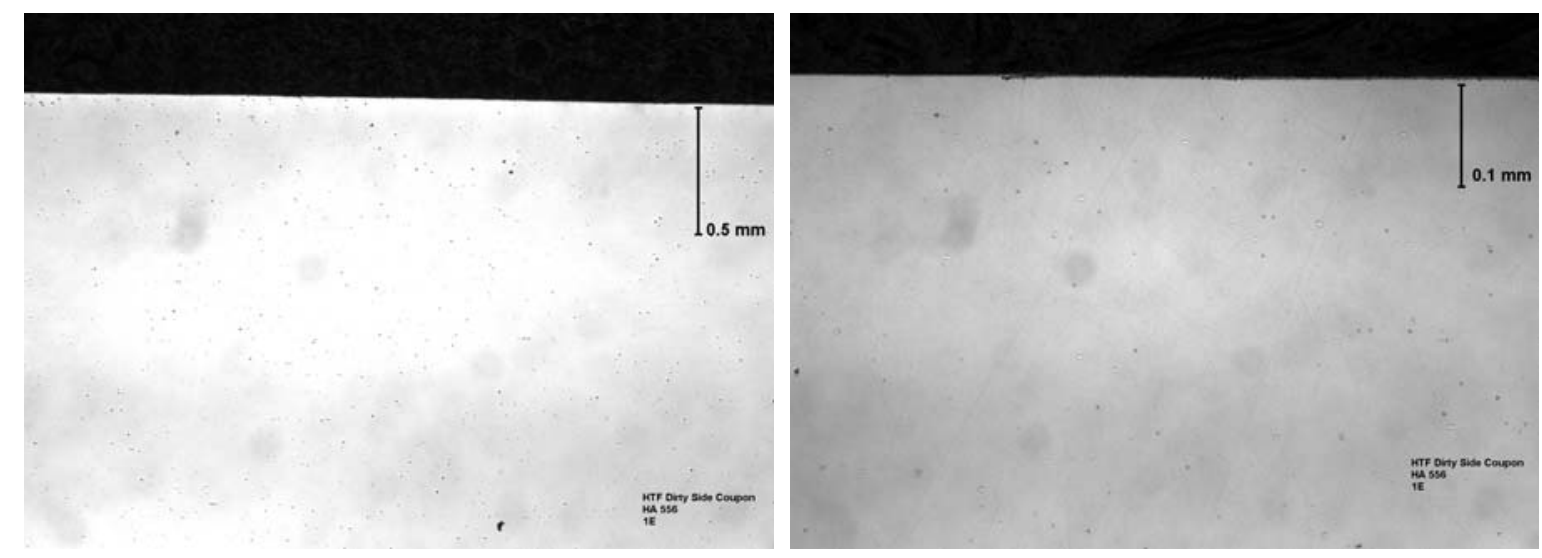

Figure 18: Metallographic Cross Section of Coupon 1E - Haynes 556 Alloy Exposed to HTF Dirty Side
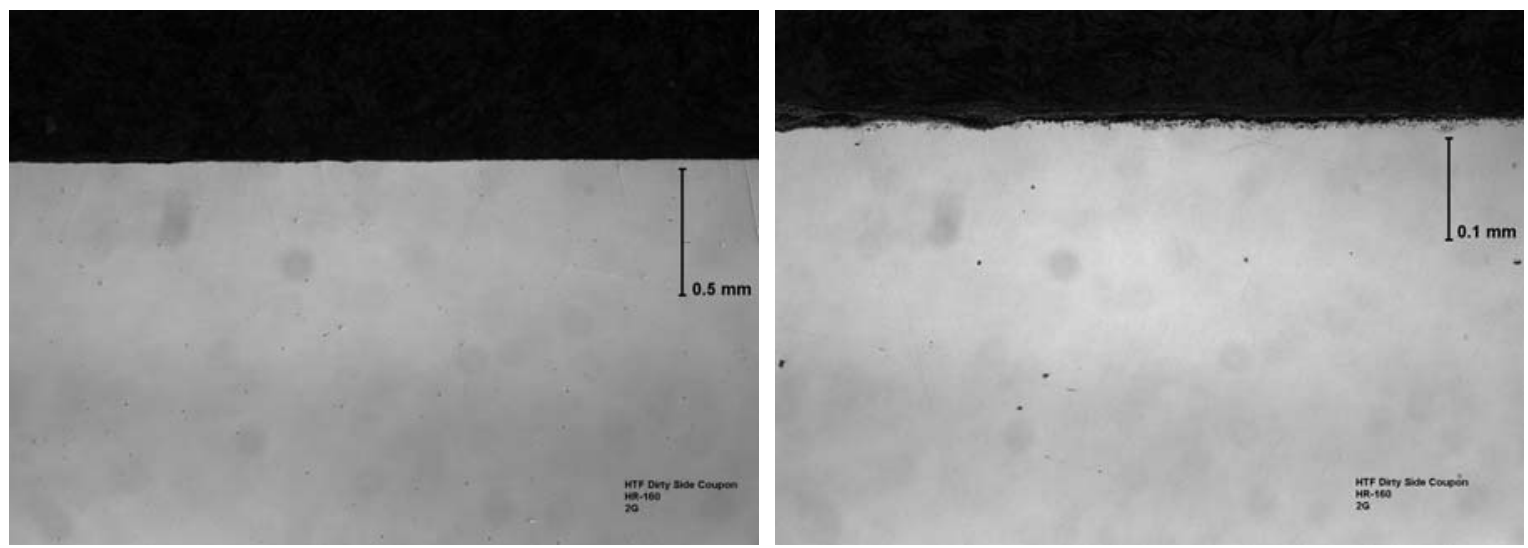

Figure 19: Metallographic Cross Section of Coupon 2G - Haynes HR-160 Alloy Exposed to HTF Dirty Side
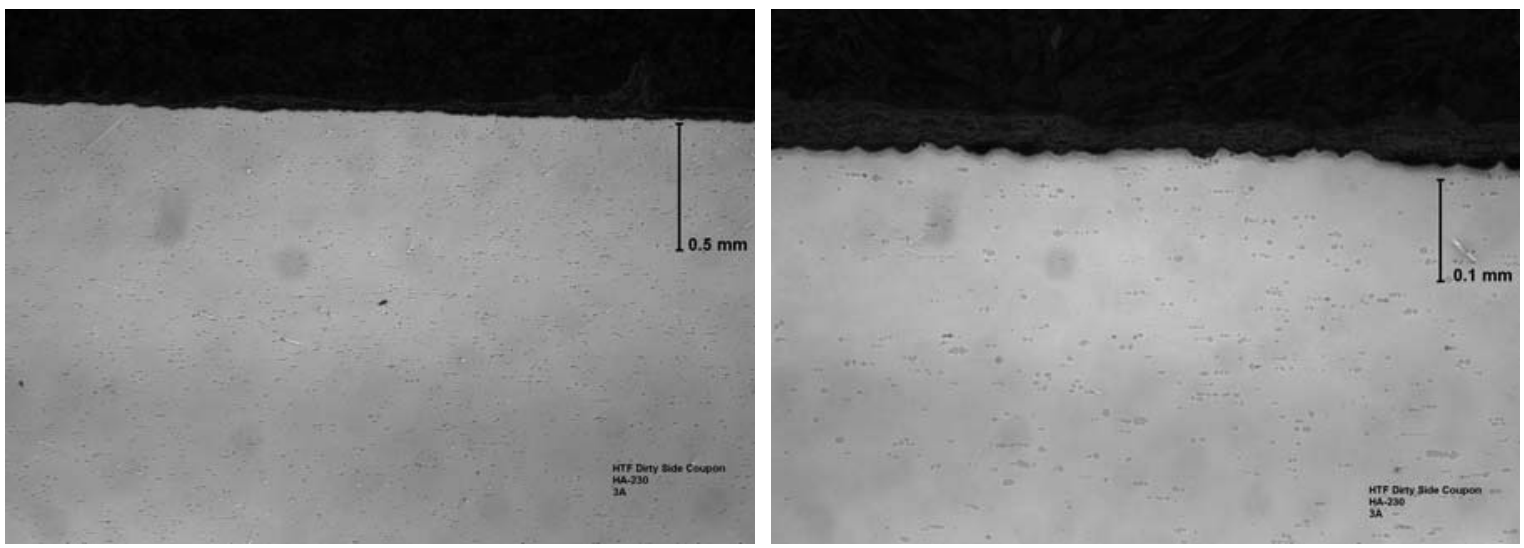

Figure 20: Metallographic Cross Section of Coupon 3A - Haynes 230 Alloy Exposed to HTF Dirty Side 

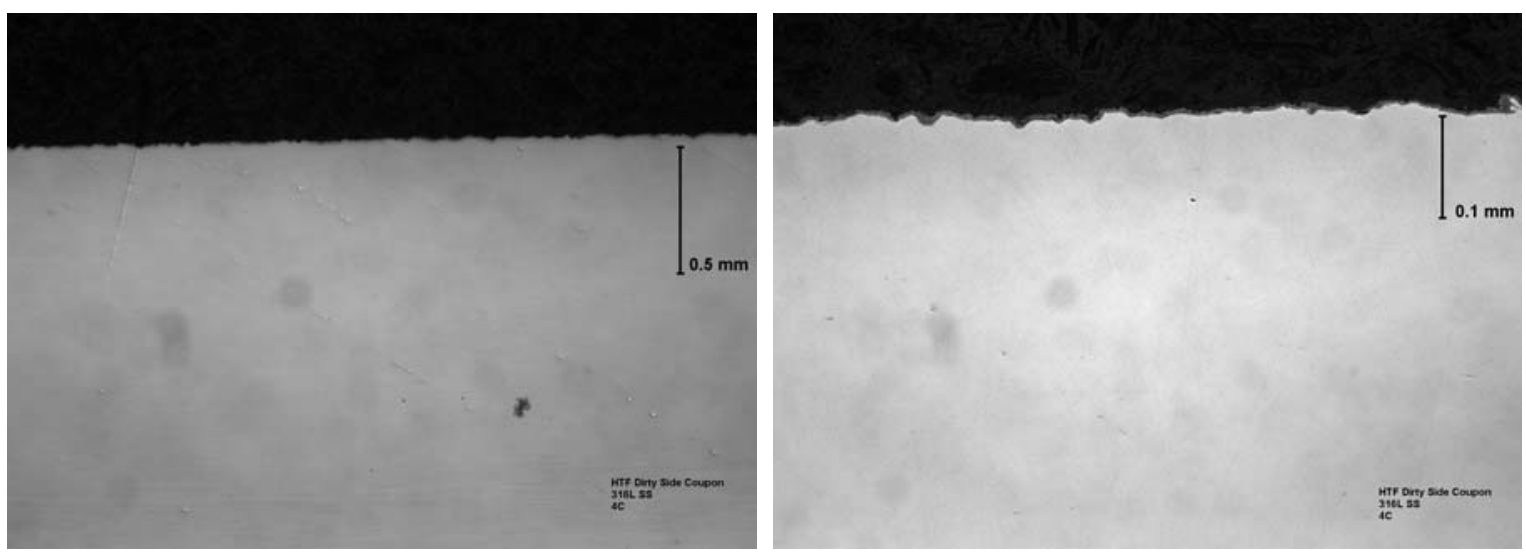

Figure 21: Metallographic Cross Section of Coupon 4C - 316L SS Alloy Exposed to HTF Dirty Side.

\subsubsection{Swatches Exposed to HTF Dirty Side}

The high temperature filter removes the finely divided product solids and charcoal fines that elutriate out of the DMR with the process gas stream. The swatches are fiber metal filter systems made of the alloys listed, including Inconel 601, a VDM alloy and HR alloy. The coupons were exposed to the "dirty side" of the HTF, or just prior to the filter medium in the process stream. There is evidence of significant process deposits on the swatches as expected. The swatches were mounted vertically from a wire/rod in close proximity to each other on the flat face, with one short edge down in downward gas flow, as shown in Figure 22. The nominal average temperature in this region of the process was $520^{\circ} \mathrm{C} \pm 40^{\circ} \mathrm{C}$.

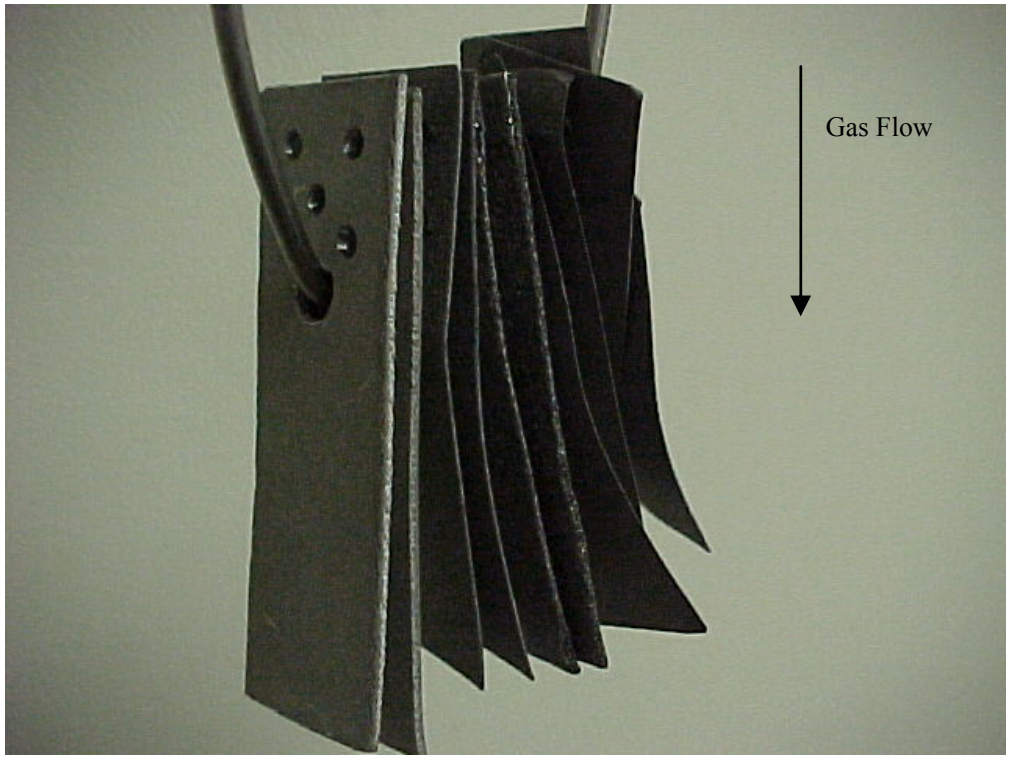

Figure 22: Swatches Exposed to the HTF Dirty Side

Photographs and the XRD deposit analysis of the HTF Swatches are shown in Table 8 
Table 8: Swatches Exposed to the HTF Dirty Side

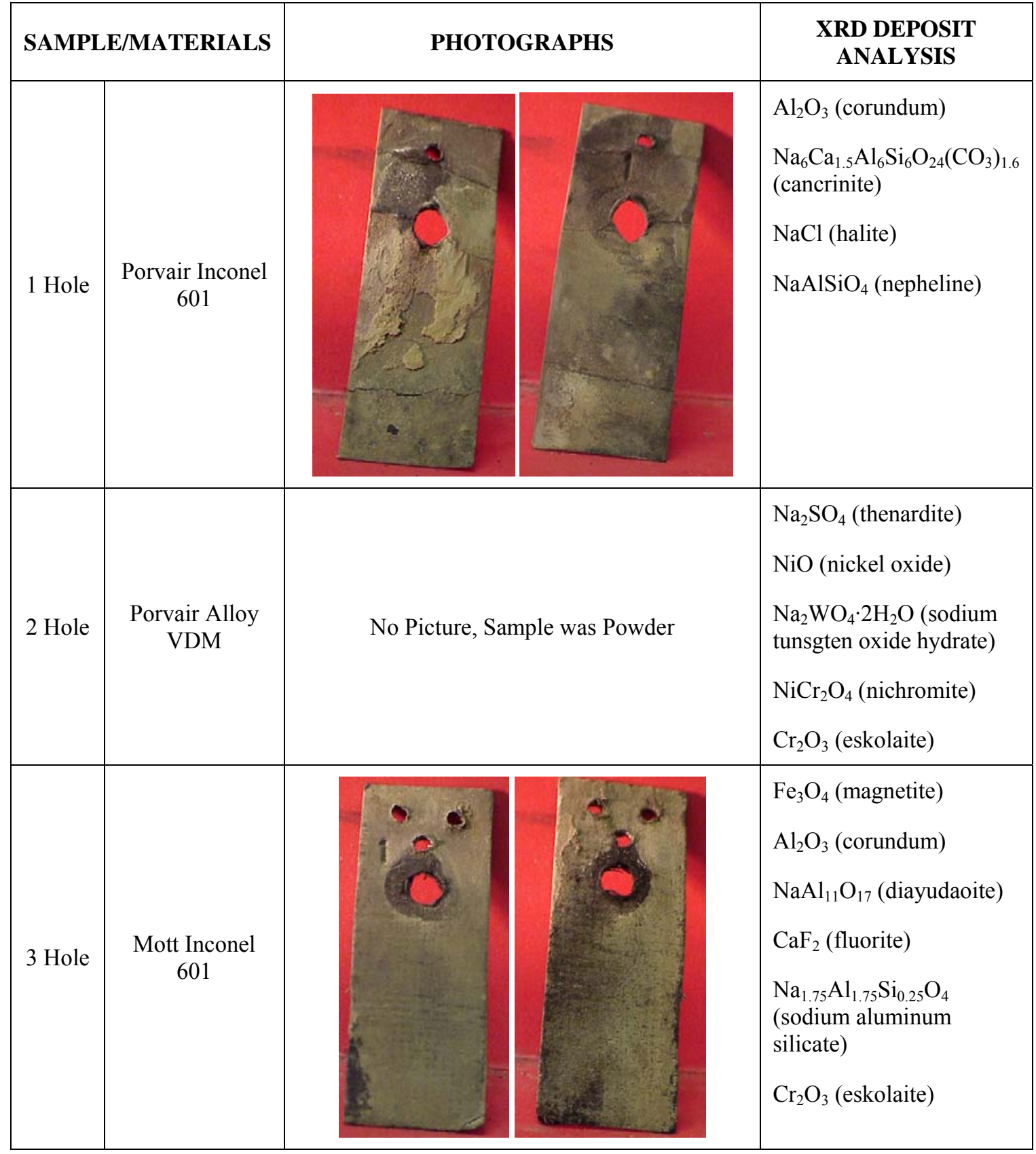




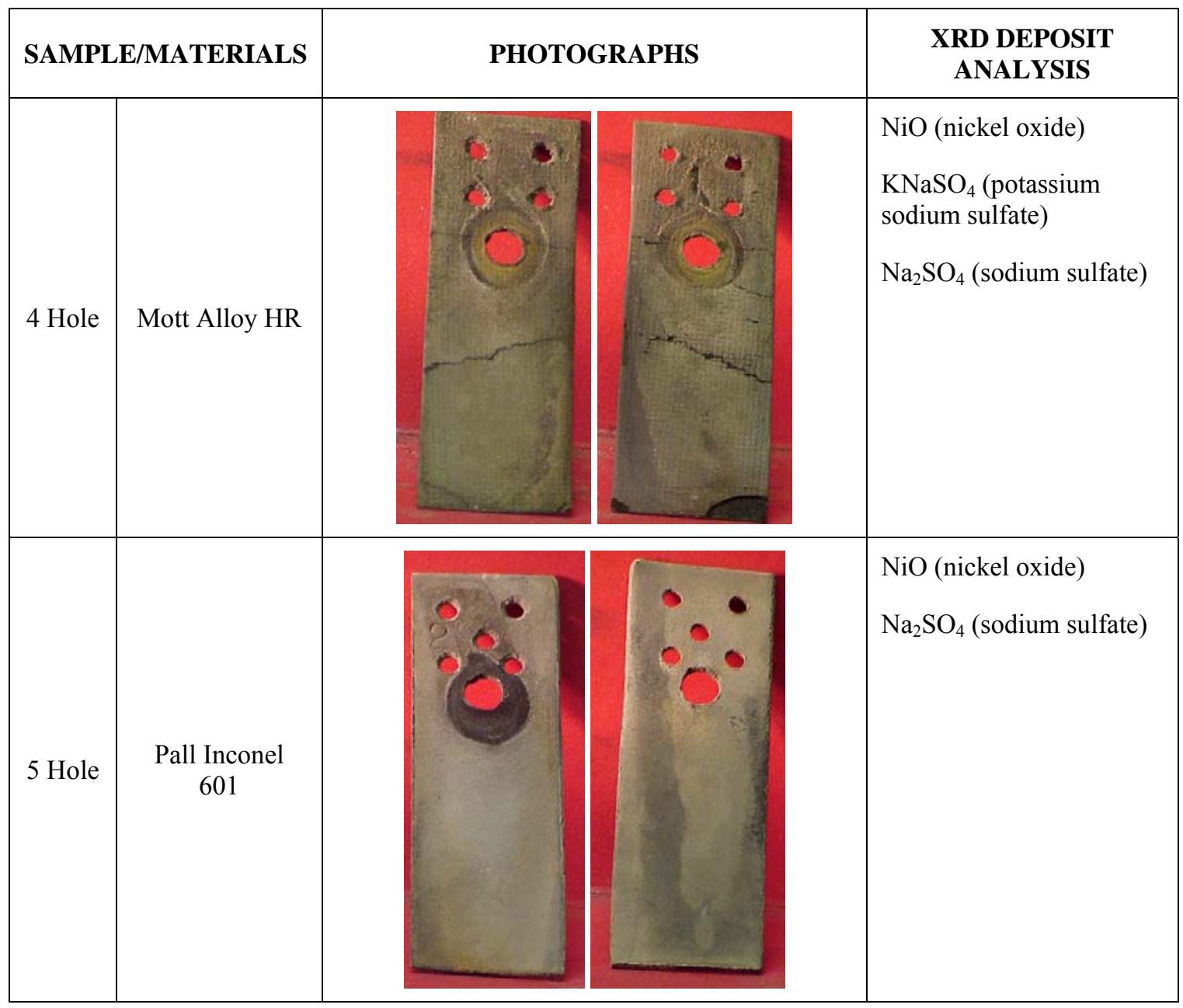

The swatches were cross sectioned, polished and photographed. The micrographs are shown in Figure 23 - 26.

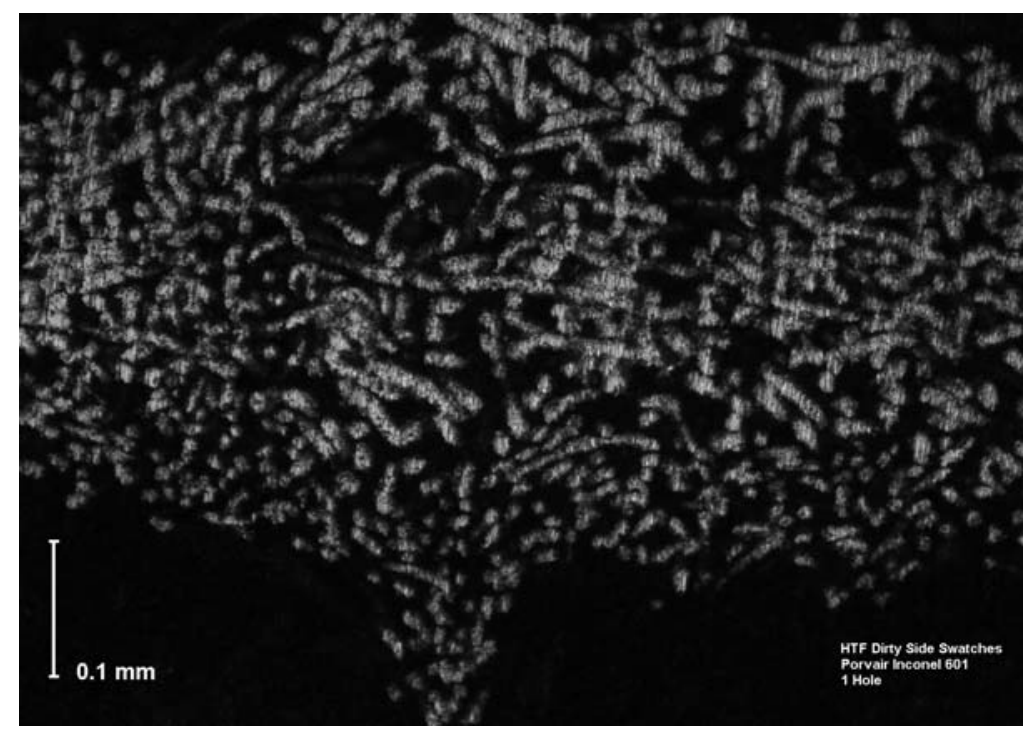

Figure 23: Metallographic Cross Section of Porvair Inconel 601 Filter Swatch Exposed to HTF Dirty Side 

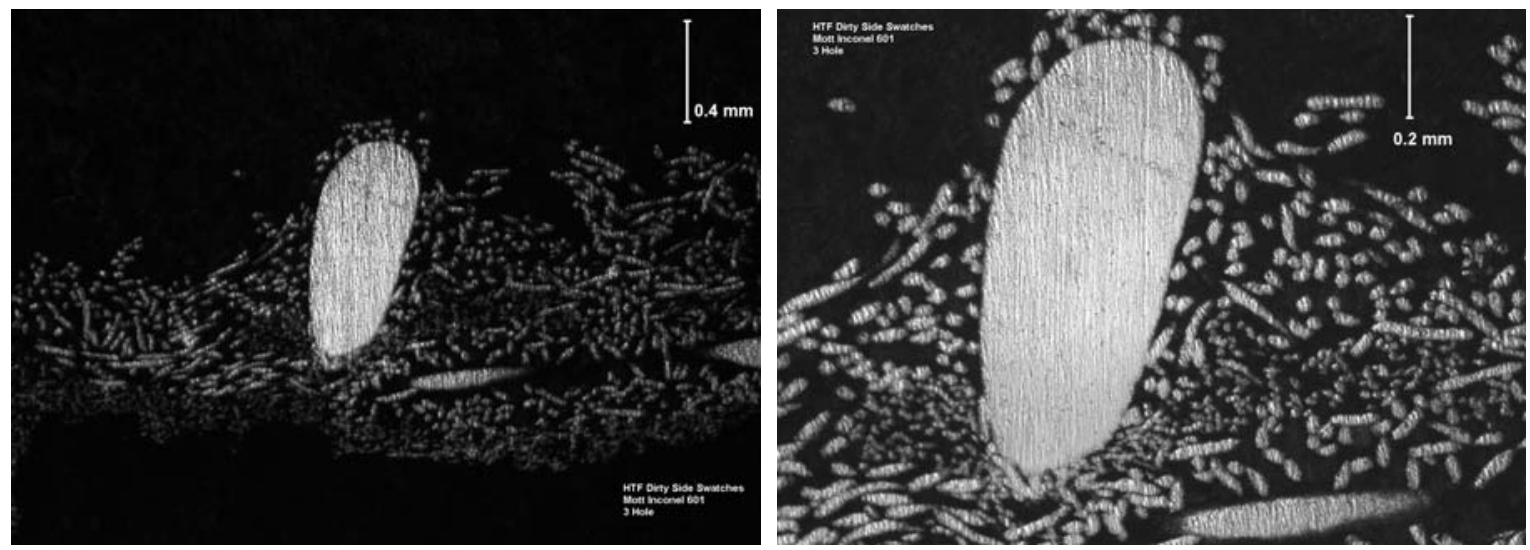

Figure 24: Metallographic Cross Section of Mott Inconel 601 Filter Swatch Exposed to HTF Dirty Side
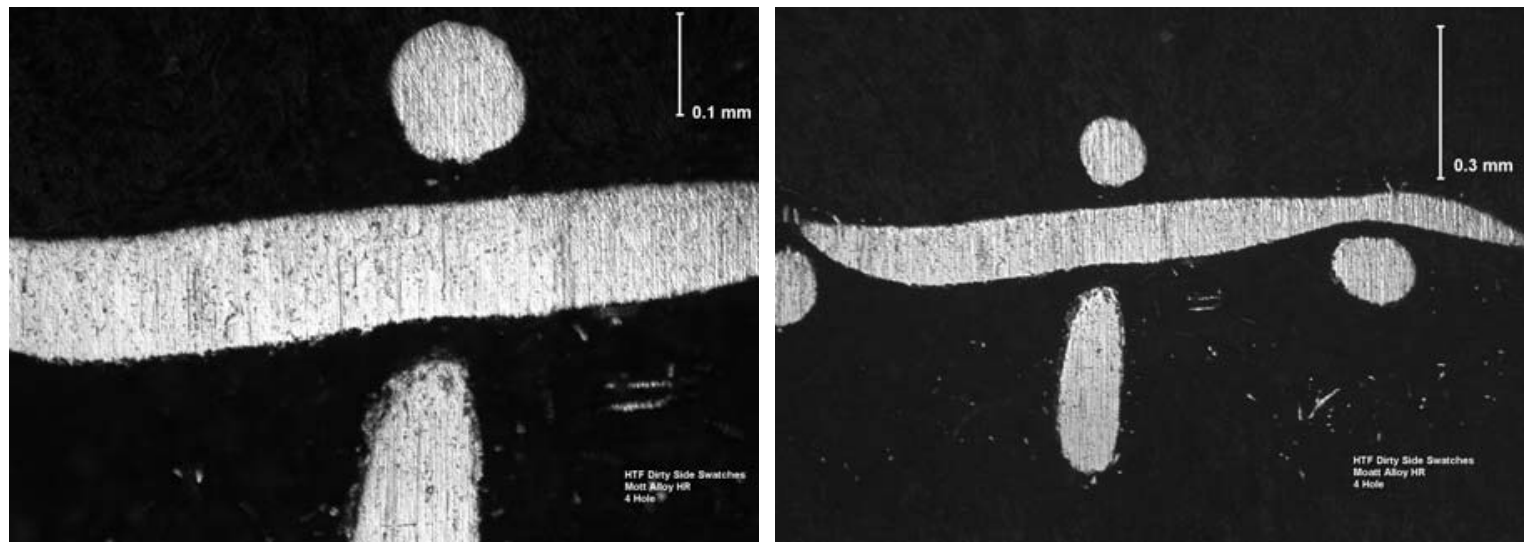

Figure 25: Metallographic Cross Section of Mott Alloy HR Filter Swatch Exposed to HTF Dirty Side
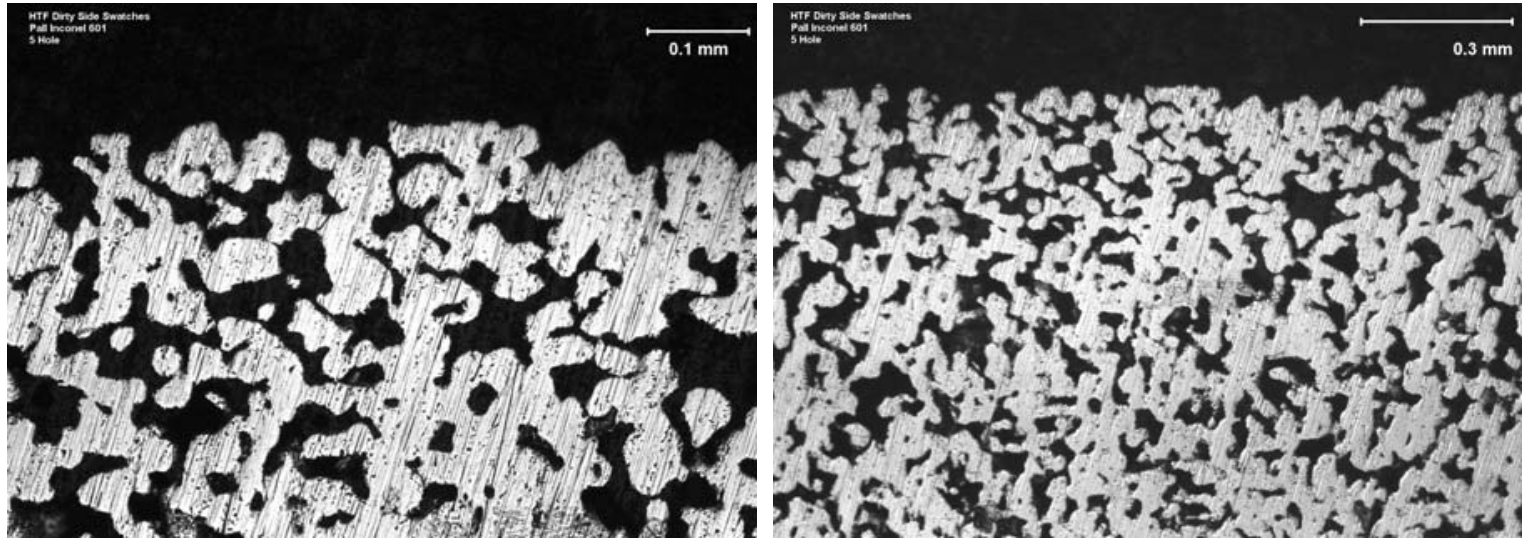

Figure 26: Metallographic Cross Section of Pall Inconel 601 Swatch Exposed to HTF Dirty Side

The micrographs and photographs showing overall condition of the swatches were used to rank these coupons. The Pall Inconel 601 Alloy appeared to have superior performance in this environment. However, it was clear the swatches did not retain sufficient integrity to maintain filter functionality. The orientation of the coupons played a key role in the degradation of the filters, as the process deposits were minimal on the Pall Inconel swatch while extensive on several of the other swatches. 


\subsection{5}

\section{Coupons Exposed to Reducing CRR Bed}

The filtered gas stream is then introduced into the bottom of the second fluidized bed steam reformer, the Carbon Reduction Reformer (CRR). A measured quantity of oxygen-enriched air is also introduced into the bottom of the CRR through a second set of distributors located just above the fluidizing process gas distributors. The CRR, operating in a reducing mode in the bottom of the fluidized bed and in an oxidizing mode in the upper section and freeboard, oxidizes the hydrogen, carbon monoxide, and organics in the gas stream to carbon dioxide and water. This section details the corrosion analysis of the reducing part of the CRR bed. The coupons in this section were mounted horizontally to the fluidizing gas distributor at approximately 45 degrees to upward (turbulent) gas flow with one long edge down, as shown in Figure 27 . The nominal average temperature was $950^{\circ} \mathrm{C} \pm 100^{\circ} \mathrm{C}$.
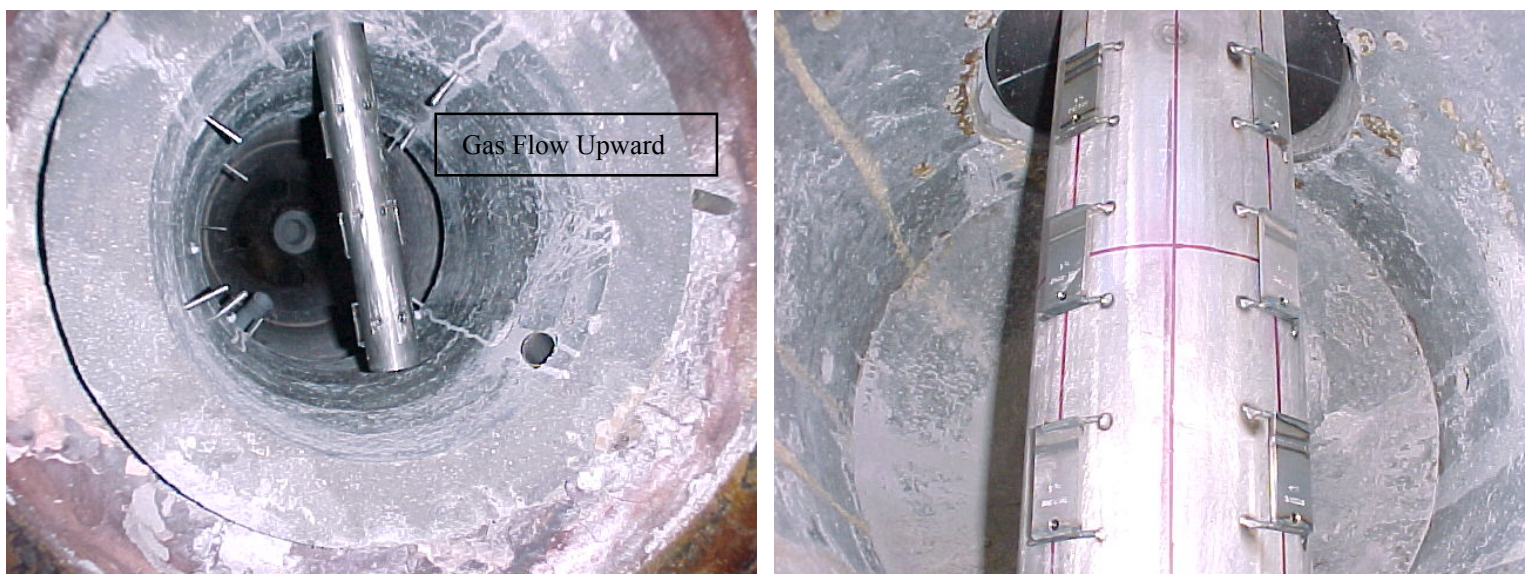

Figure 27: Coupons Exposed to CRR Bed

The pictures of the coupons are shown in Table 9. The coupons showed pervasive corrosion with significant erosion on the coupons, indicated by the smoothness on the edges. There was evidence of process deposits on the coupon, including silicates, sulfates, and phosphates.

Table 9: Coupons Exposed to Reducing CRR Bed

\begin{tabular}{|c|c|c|c|}
\hline COUPON & MATERIAL & PHOTOGRAPHS & XRD DEPOSIT ANALYSIS \\
\hline $1 \mathrm{H}$ & Haynes 556 & & $\begin{array}{l}\mathrm{Ca}_{2.993} \mathrm{H}_{0.014}\left(\mathrm{PO}_{4}\right)_{2} \text { (whitlockite) } \\
\mathrm{Ca}\left(\mathrm{Al}_{2} \mathrm{Si}_{2} \mathrm{O}_{6}\right) \text { (anorthite) } \\
\mathrm{NaAlSiO}_{4} \text { (nepheline) } \\
\mathrm{MgCaSiO}_{4} \text { (monticellite) }\end{array}$ \\
\hline
\end{tabular}




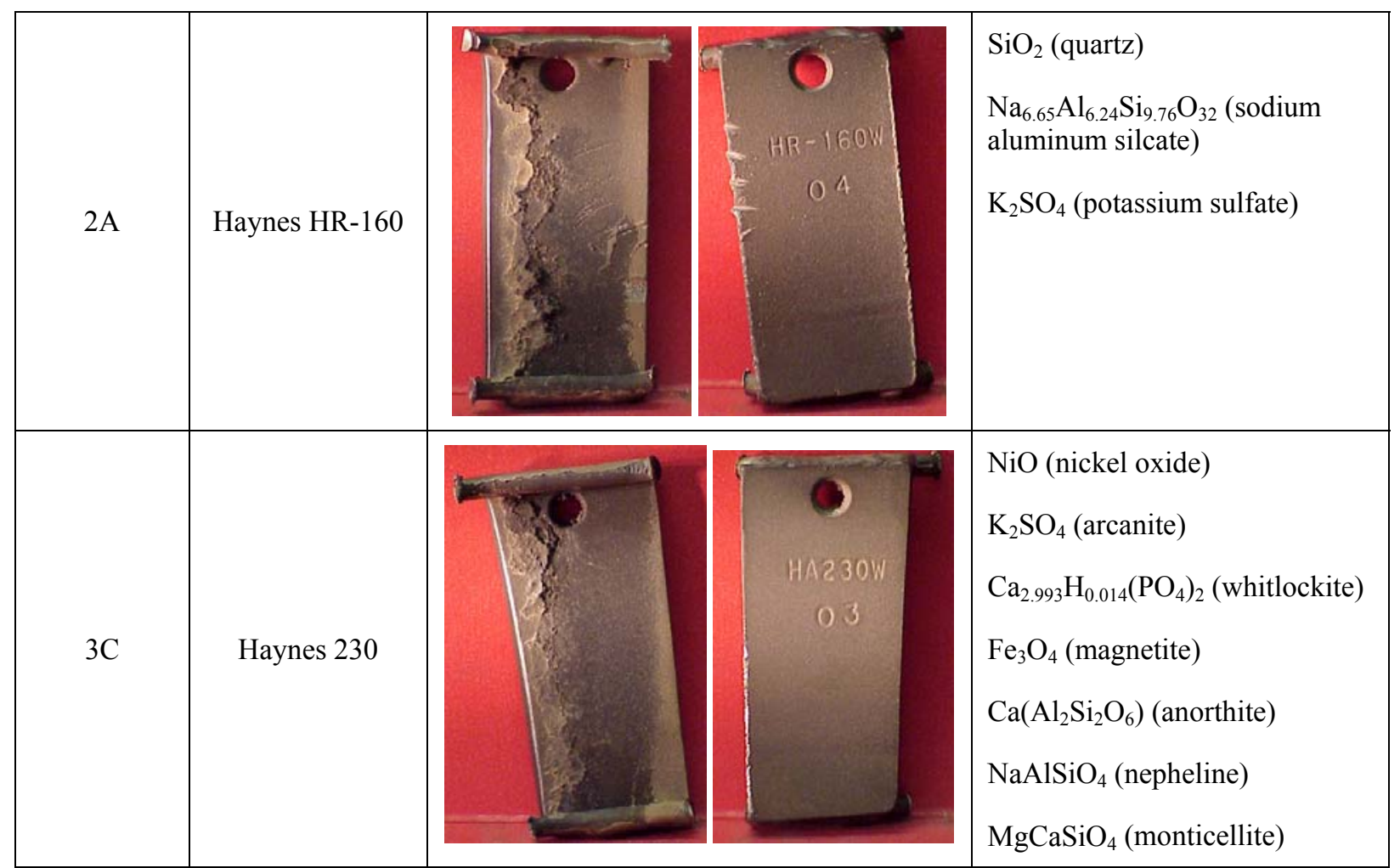

The placement of the coupon in the process stream plays a significant role in the erosion of the coupon. The erosion resistance of these alloys is expected to be similar; however, it appears that the HR-160 eroded less than the other alloys. The micrographs of the coupons exposed to the CRR bed reducing are shown in Figure $28-30$. All the alloys exhibited relatively straight corrosion fronts, with evidence of intergranular attack and dealloying at the surface.

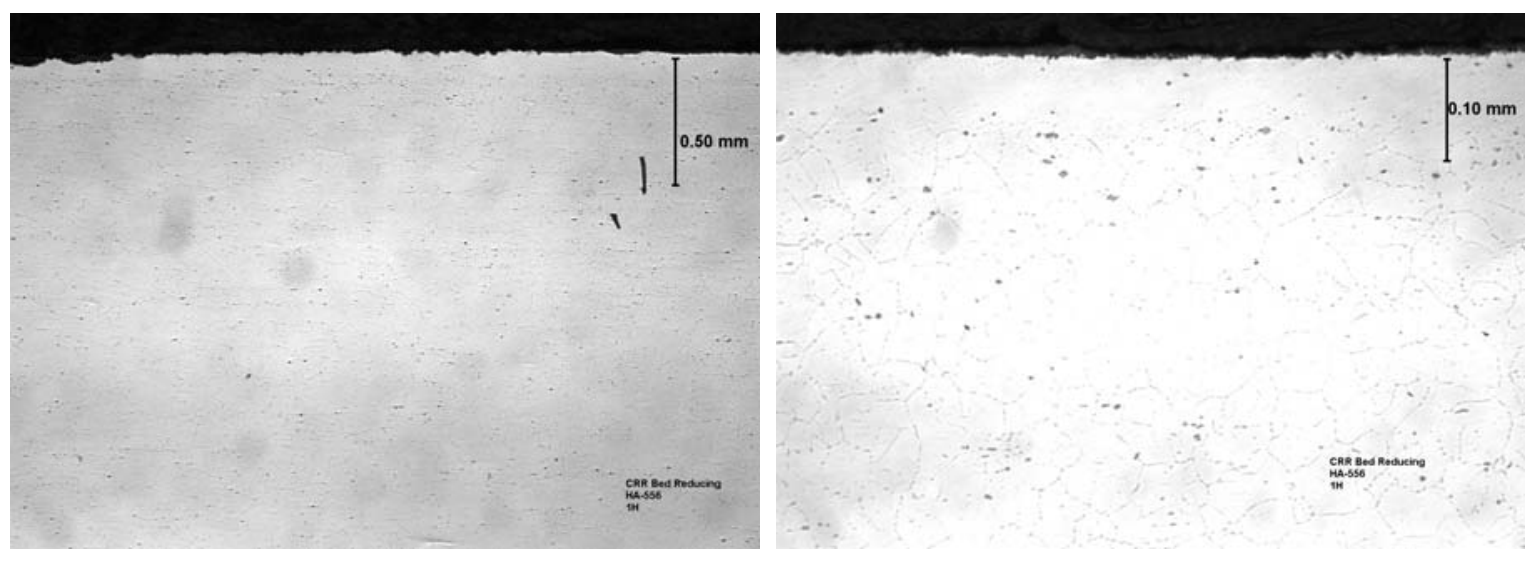

Figure 28: Metallographic Cross Section of Coupon 1H - Haynes 556 Alloy Exposed to CRR Reducing 

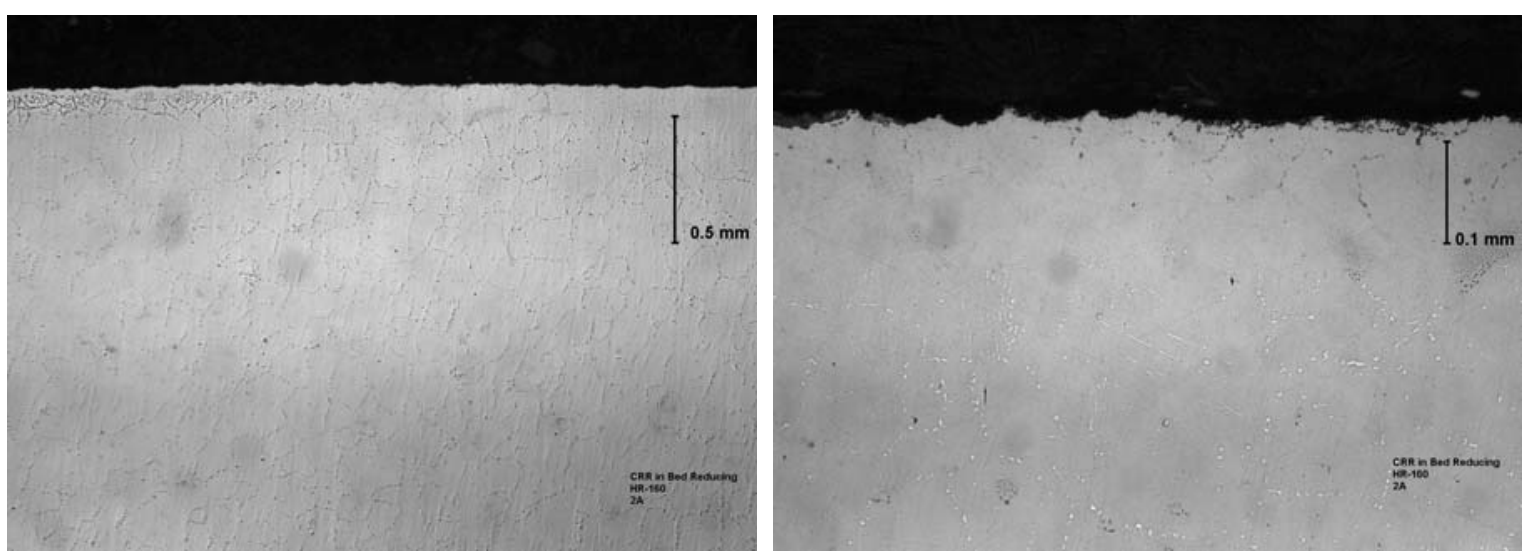

Figure 29: Metallographic Cross Section of Coupon 2A - Haynes HR-160 Alloy Exposed to CRR Reducing
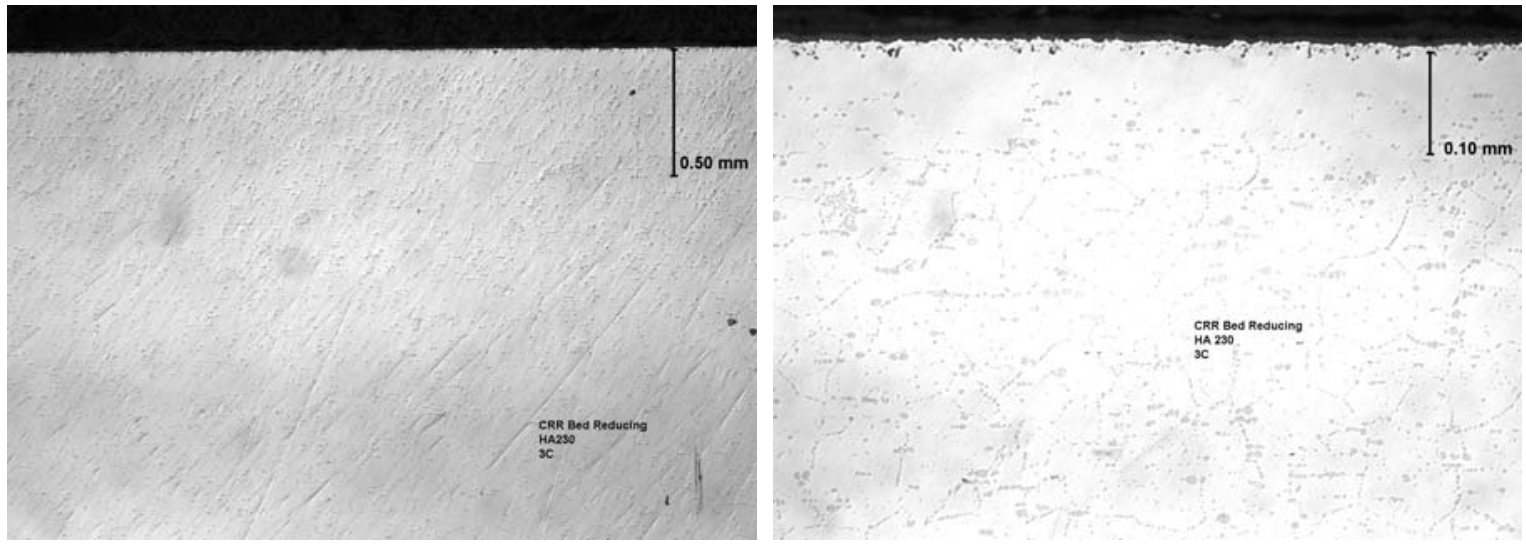

Figure 30: Metallographic Cross Section of Coupon 3C - Haynes 230 Alloy Exposed to CRR Reducing

The "dealloyed" region is shown in Figure 31. The region is near surface and a region denuded of distinguishable grain boundaries is seen in the micrograph. This phenomenon is most likely due to diffusion related process at these temperatures, but can be considered a corrosion process. The phenomenon could also be due to a combination of erosion/corrosion mechanisms. 


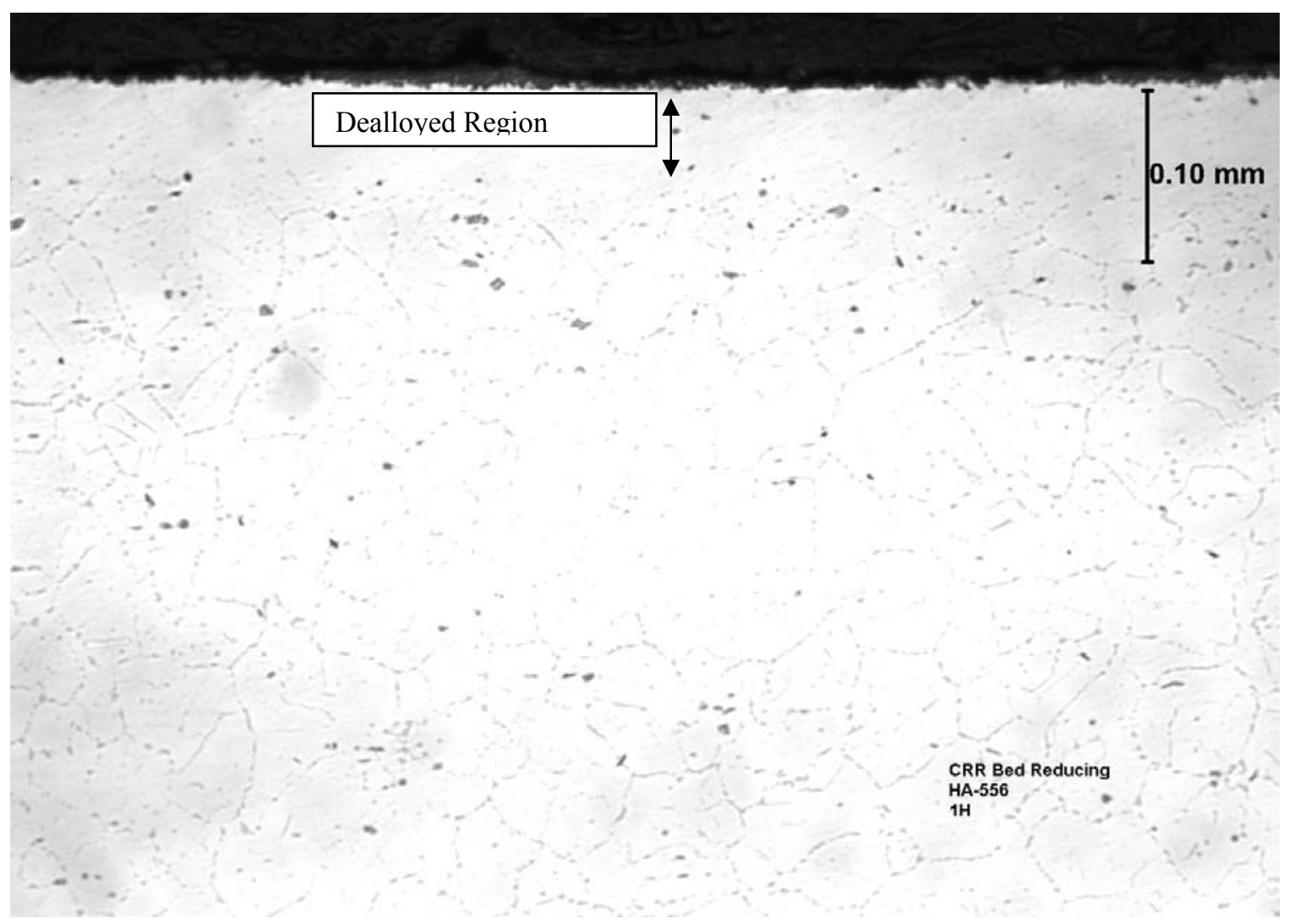

Figure 31: Metallographic Cross Section of Coupon 1H - Haynes 556 Alloy Exposed to CRR Reducing Showing Dealloying at the Surface

In the temperature and environmental regimes that the coupons in the reducing part of the CRR bed were exposed to, the key corrosion mechanisms would be nitridation and the combination of erosion and corrosion. SEM/EDX analysis was completed to postulate the extent of each of these mechanisms. Nitridation is unique in that the formation of nitrides (primarily iron, chromium, and cobalt) can lead to the embrittlement of the alloy. Even though not a direct corrosion mechanism that leads to metal wastage, nitridation has a significant effect on the mechanical behavior of materials, particularly for pressure vessels.

In addition, erosion corrosion mechanisms were considered because of the high temperature gas flow, and the clear evidence of wear on the coupons. The synergism between the erosion and high temperature oxidation of the materials is a complex interaction that can lead to extensive metal wastage in a relatively short period of time. In this case, the oxidation behavior of the material is limited due to the reducing environment provided by the gas stream, however, erosion is still evident. The synergism between the erosion and high temperature degradation can be considered a competition between the oxide scale thickening and the oxide stability and consequent resistance to thinning/breakdown by erosion.[9] It is this transient nature of oxide stability that can enhance the metal wastage due to the synergistic effects. As such, the resistance of the alloys to the erosion-corrosion mechanism is dependent upon the tenacity and morphology of the oxide layer.[10]

The SEM/EDX of the coupons exposed to the reducing portion of the CRR bed are shown in Figure $32-34$. The analyses indicated the lack of an oxide on the surface of the Haynes 556 alloy, with iron as the primarily chemical constituent. The HR-160 alloy and the Haynes 230 alloy had a chromia surface oxide with underlying silica. Even though the HR-160 alloy has significantly higher silicon content than Haynes 230, silica formed on both surfaces. The silicon additions are known to provide superior oxidation resistance at relatively high temperatures where the silica can form. The enhanced resistance has been attributed to the formation of a protective and tenacious silica layer.[11] It has also been proposed that the silica layer enhances the formation of stable chromia layers and may act as a diffusion barrier.[12] 

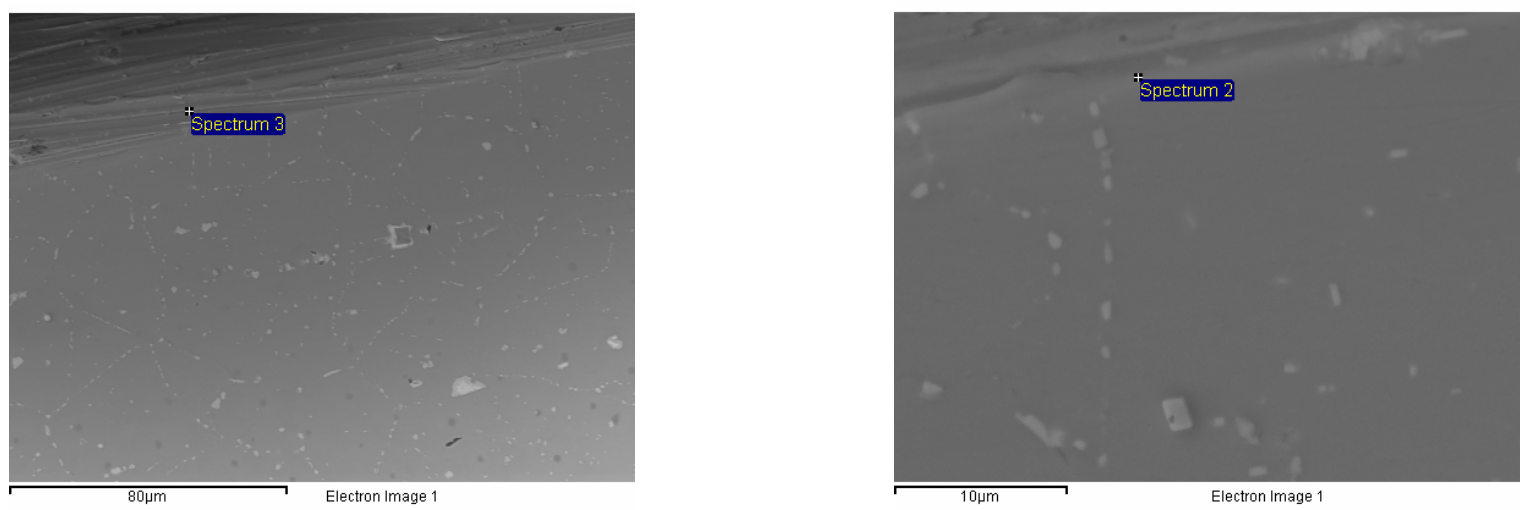

\begin{tabular}{c|cc}
\hline Element & Weight\% & Atomic\% \\
Cr K & 27.87 & 29.85 \\
Fe K & 30.09 & 29.99 \\
Co K & 21.30 & 20.13 \\
Ni K & 18.07 & 17.13 \\
\hline
\end{tabular}

\begin{tabular}{c|cc}
\hline Element & Weight\% & Atomic\% \\
O K & 0.99 & 3.43 \\
Cr K & 21.81 & 23.17 \\
Fe K & 31.88 & 31.54 \\
Co K & 20.02 & 18.77 \\
Ni K & 21.27 & 20.02 \\
\hline
\end{tabular}

Figure 32: SEM/EDX of Haynes 556 Alloy Exposed to DMR Bed Indicating Lack of Stable Oxide on Surface
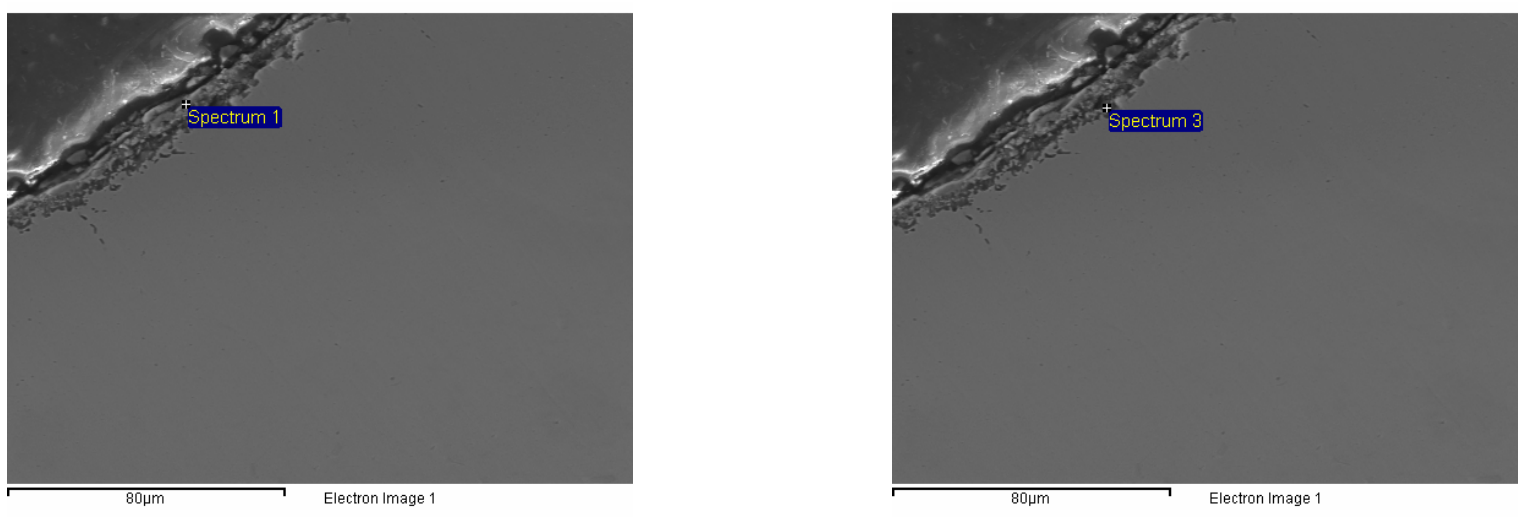

\begin{tabular}{c|cc}
\hline Element & Weight\% & Atomic\% \\
O K & 32.49 & 59.68 \\
Cr K & 55.07 & 31.11 \\
\hline
\end{tabular}

\begin{tabular}{c|cc}
\hline Element & Weight\% & Atomic\% \\
O K & 33.84 & 54.10 \\
Si K & 34.44 & 31.36 \\
Cr K & 12.46 & 6.13 \\
Co K & 9.49 & 4.12 \\
Ni K & 9.65 & 4.21 \\
\hline
\end{tabular}

Figure 33: SEM/EDX of Haynes HR-160 Alloy Exposed to DMR Bed Indicating Stable Oxide on Surface 

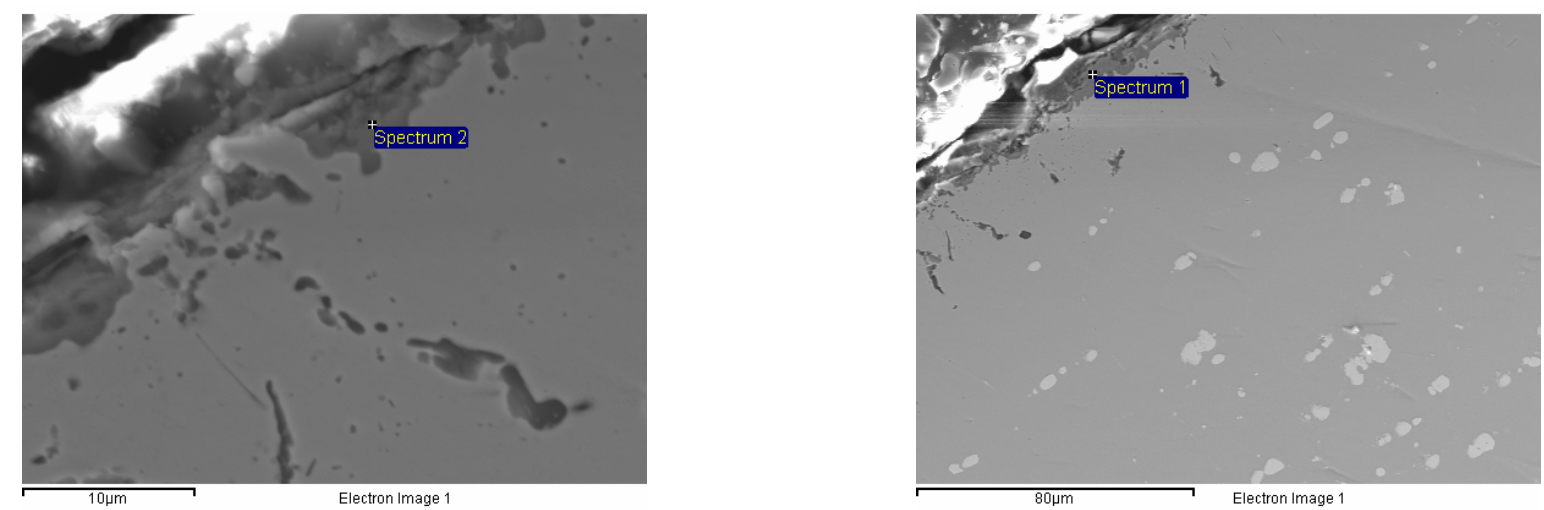

\begin{tabular}{c|cc}
\hline Element & Weight\% & Atomic\% \\
O K & 32.26 & 56.16 \\
Cr K & 53.68 & 28.75 \\
\hline
\end{tabular}

\begin{tabular}{c|cc}
\hline Element & Weight\% & Atomic\% \\
O K & 23.33 & 45.82 \\
Si K & 7.17 & 8.02 \\
Cr K & 56.63 & 34.22 \\
\hline
\end{tabular}

Figure 34: SEM/EDX of Haynes 230 Alloy Exposed to DMR Bed Indicating Stable Oxide on Surface

The SEM analysis also indicated the formation of internal voids on the Haynes 230 alloys. However, there was no evidence of nitridation on any of the coupons.

\subsubsection{Coupons Exposed to Oxidizing CRR Bed}

This section details the corrosion analysis of the coupons exposed to the oxidizing part of the CRR bed. As with the coupons exposed in the reducing side, the coupons were mounted horizontally to the autothermal gas distributor at approximately 45 degrees to upward (turbulent) gas flow. The pictures of the coupons are shown in Table 10. The coupons showed extreme and potentially breakaway corrosion where extreme localized corrosion led to the spalling of large sections of coupon, when temperatures are at a critical intermediate temperature, i.e. approximately 600$800^{\circ} \mathrm{C}$. There was evidence of process deposits on the coupon, primarily silicates. The nominal average temperature was $950^{\circ} \mathrm{C} \pm 100^{\circ} \mathrm{C}$.

Table 10: Coupons Exposed to Oxidizing CRR Bed

\begin{tabular}{|c|c|c|c|}
\hline COUPON & MATERIAL & PHOTOGRAPHS & XRD DEPOSIT ANALYSIS \\
\hline $1 \mathrm{~J}$ & Haynes 556 & 28 & $\begin{array}{l}\left(\mathrm{CoFe}_{2}\right) \mathrm{O}_{4} \text { (cobalt iron oxide) } \\
\mathrm{NaAlSiO}_{4} \text { (nepheline) } \\
\mathrm{NiO} \text { (nickel oxide) } \\
\mathrm{Fe}_{2} \mathrm{O}_{3} \text { (hematite) } \\
\mathrm{Na}_{1.75} \mathrm{Al}_{1.75} \mathrm{Si}_{0.25} \mathrm{O}_{4} \text { (sodium } \\
\text { aluminum silicate) } \\
\mathrm{Ca}_{2.993} \mathrm{H}_{0.014}\left(\mathrm{PO}_{4}\right)_{2} \text { (whitlockite) }\end{array}$ \\
\hline
\end{tabular}




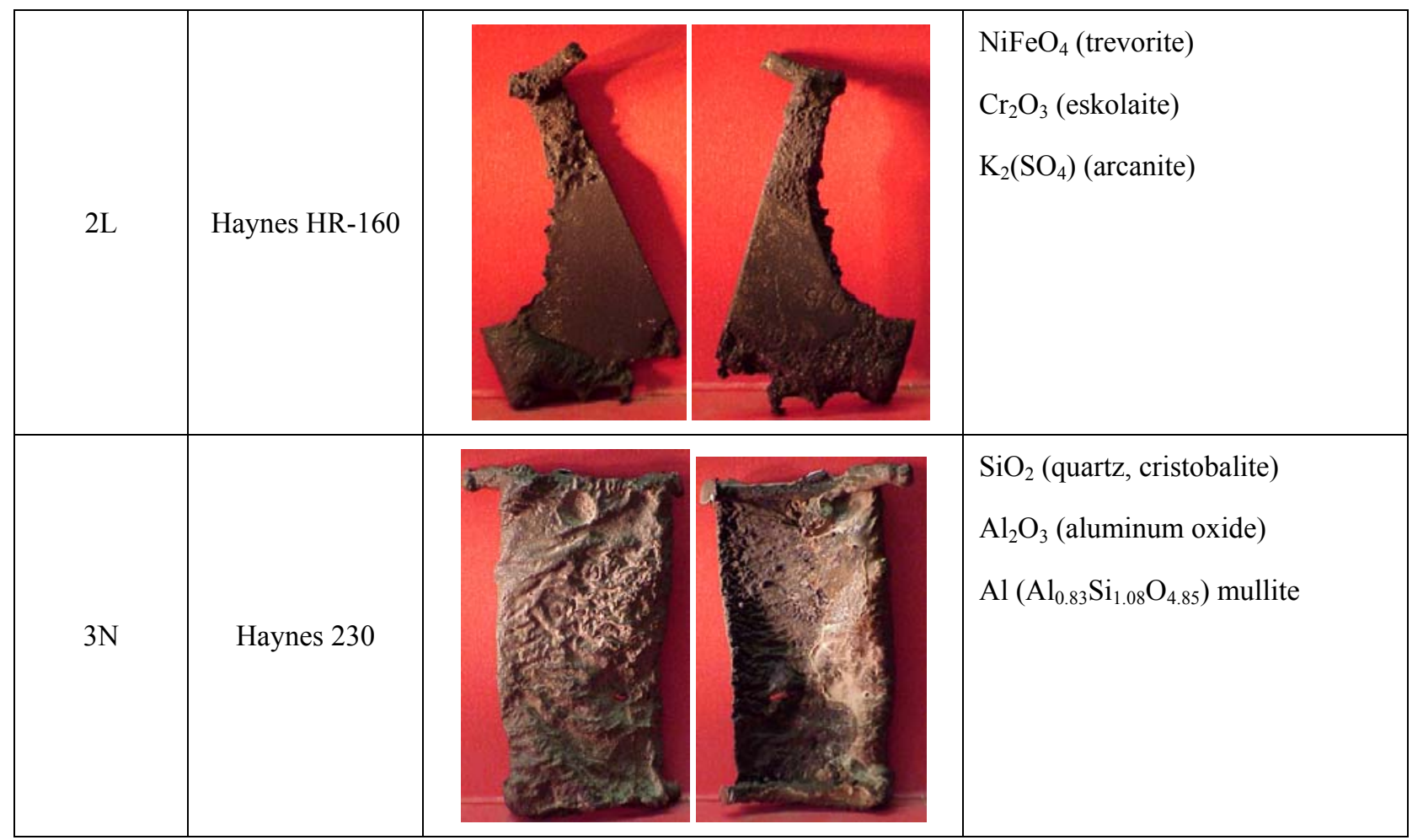

The metallographic analyses of the coupons are shown in Figure 35 - 37. The cross sections show surface dealloying with significant internal attack. Once again, the placement of the coupon in the process stream is suspected to influence the corrosion response. The Haynes 230 alloy shows evidence of potential incipient melting based upon the overall photograph. The Haynes HR-160 alloy appeared to have experienced breakaway corrosion.
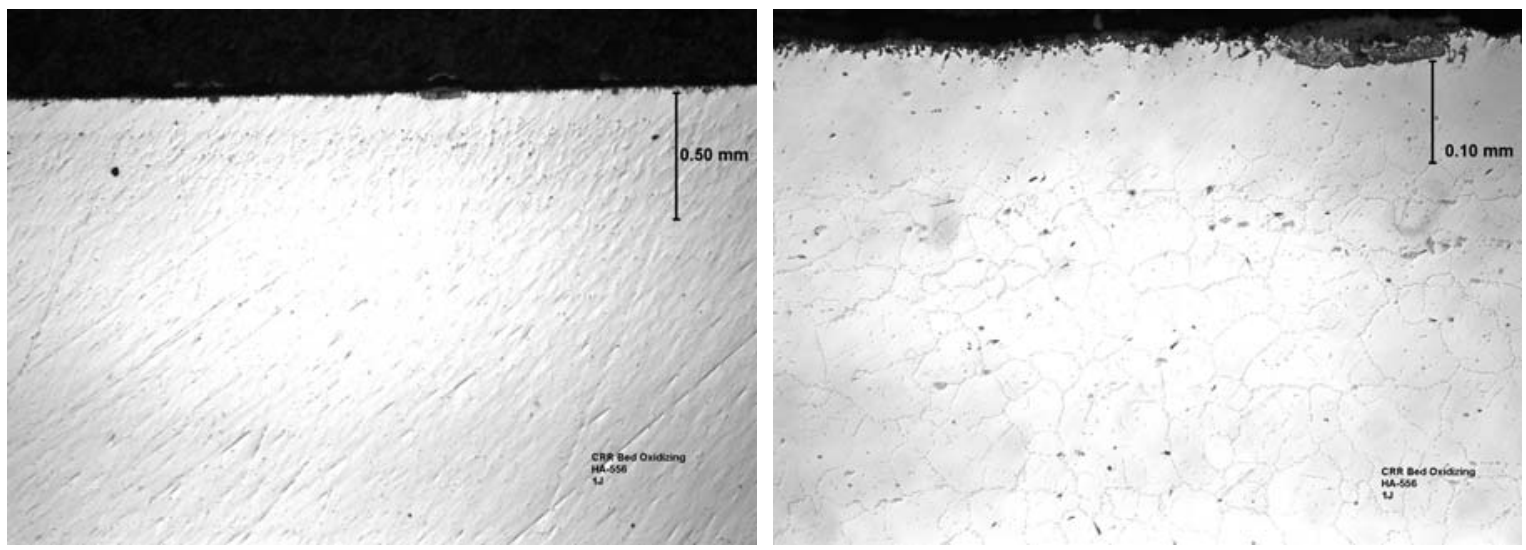

Figure 35: Metallographic Cross Section of Coupon 1J - Haynes 556 Alloy Exposed to CRR Oxidizing 

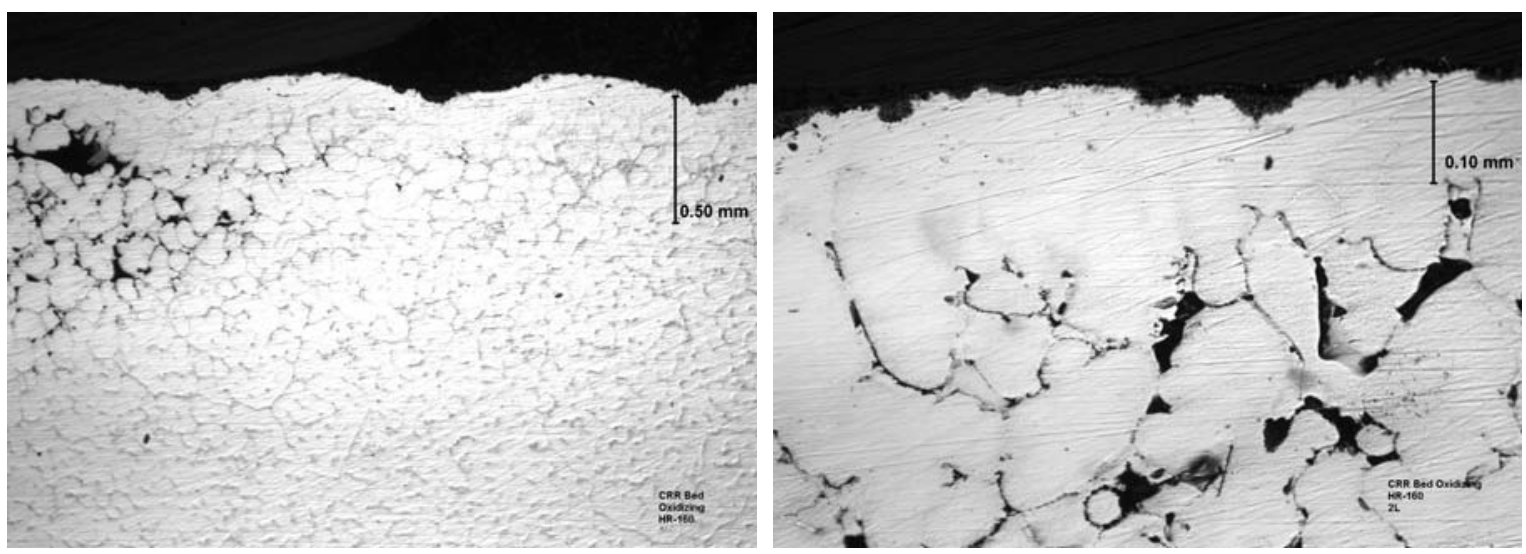

Figure 36: Metallographic Cross Section of Coupon 2L - Haynes HR-160 Alloy Exposed to CRR Oxidizing
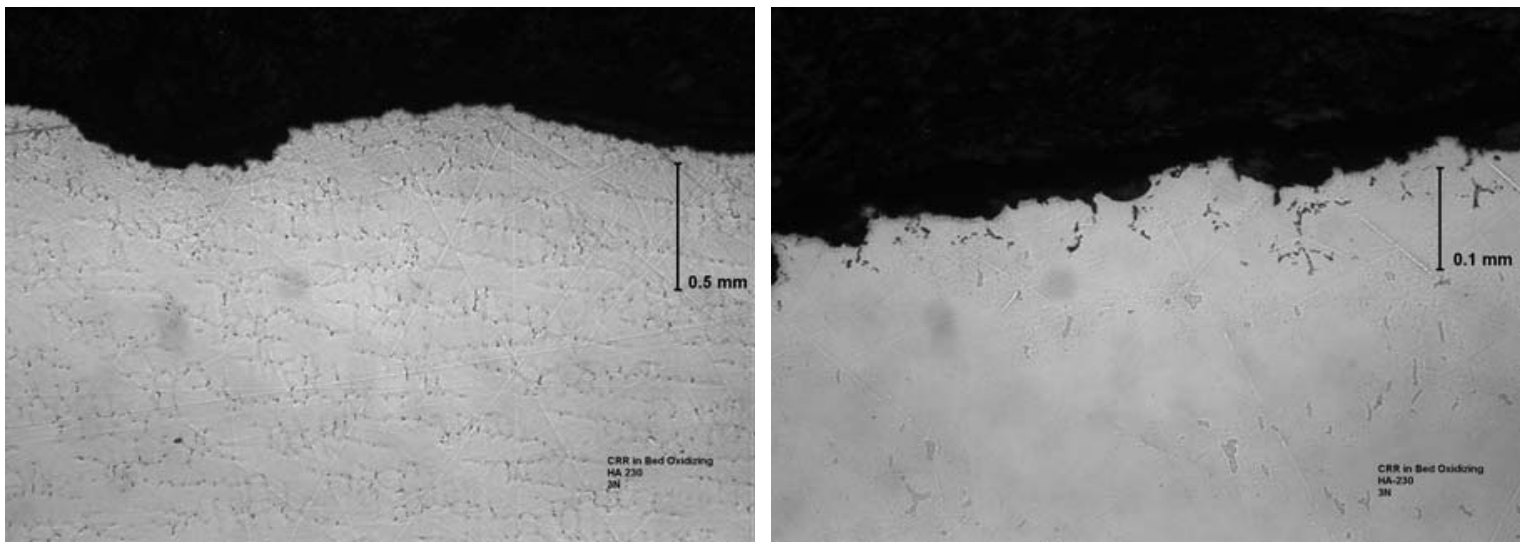

Figure 37: Metallographic Cross Section of Coupon 3N - Haynes 230 Alloy Exposed to CRR Oxidizing

All alloys tested in this section of the process exhibited significant corrosion. It is recommended that the alloys be protected with a high-temperature refractory. Furthermore, the refractory must seal the metal completely, since incomplete sealing may create a potentially worse crevice situation.

\subsubsection{Coupons Exposed to CRR Freeboard}

The coupons exposed to the CRR freeboard were mounted vertically from a wire/rod in close proximity to each other on the flat face with one short edge (w/o hole) down in upward gas flow, as shown in Figure 38. The nominal average temperature was $850^{\circ} \mathrm{C} \pm 100^{\circ} \mathrm{C}$. 


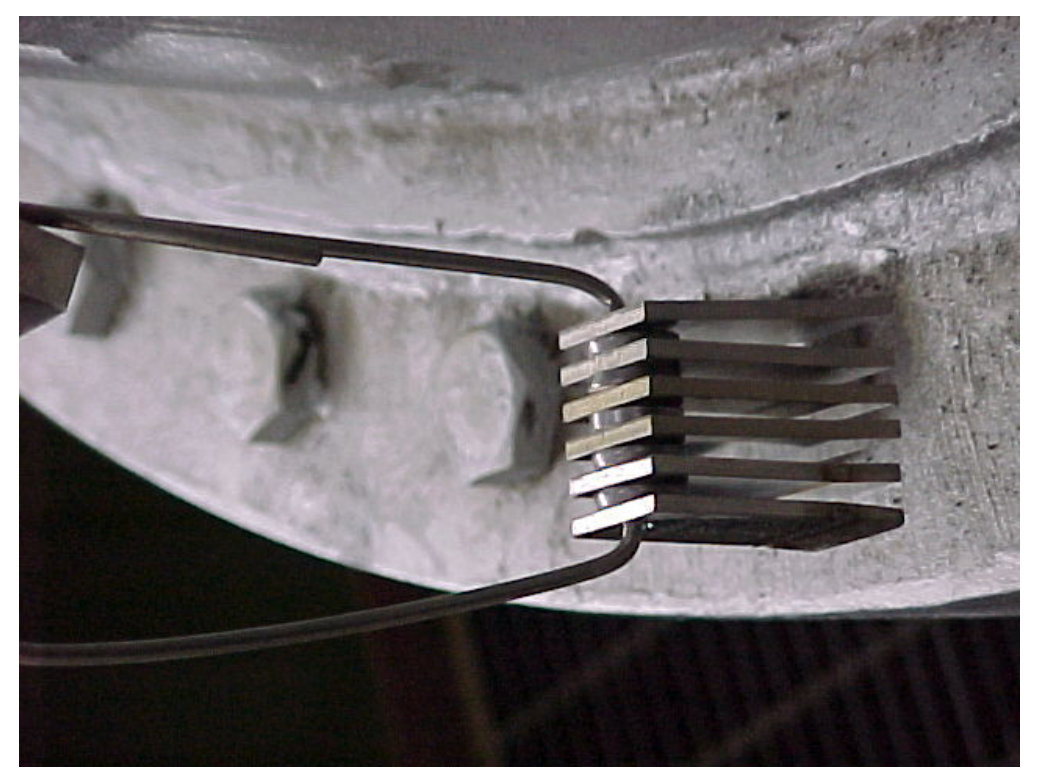

Figure 38: Coupons Exposed to the CRR Freeboard

The pictures of the coupons exposed to the freeboard above the CRR bed are shown in Table 11. The coupons showed pervasive significant corrosion, with process deposits, primarily sulfates.

Table 11: Coupons Exposed to CRR Freeboard

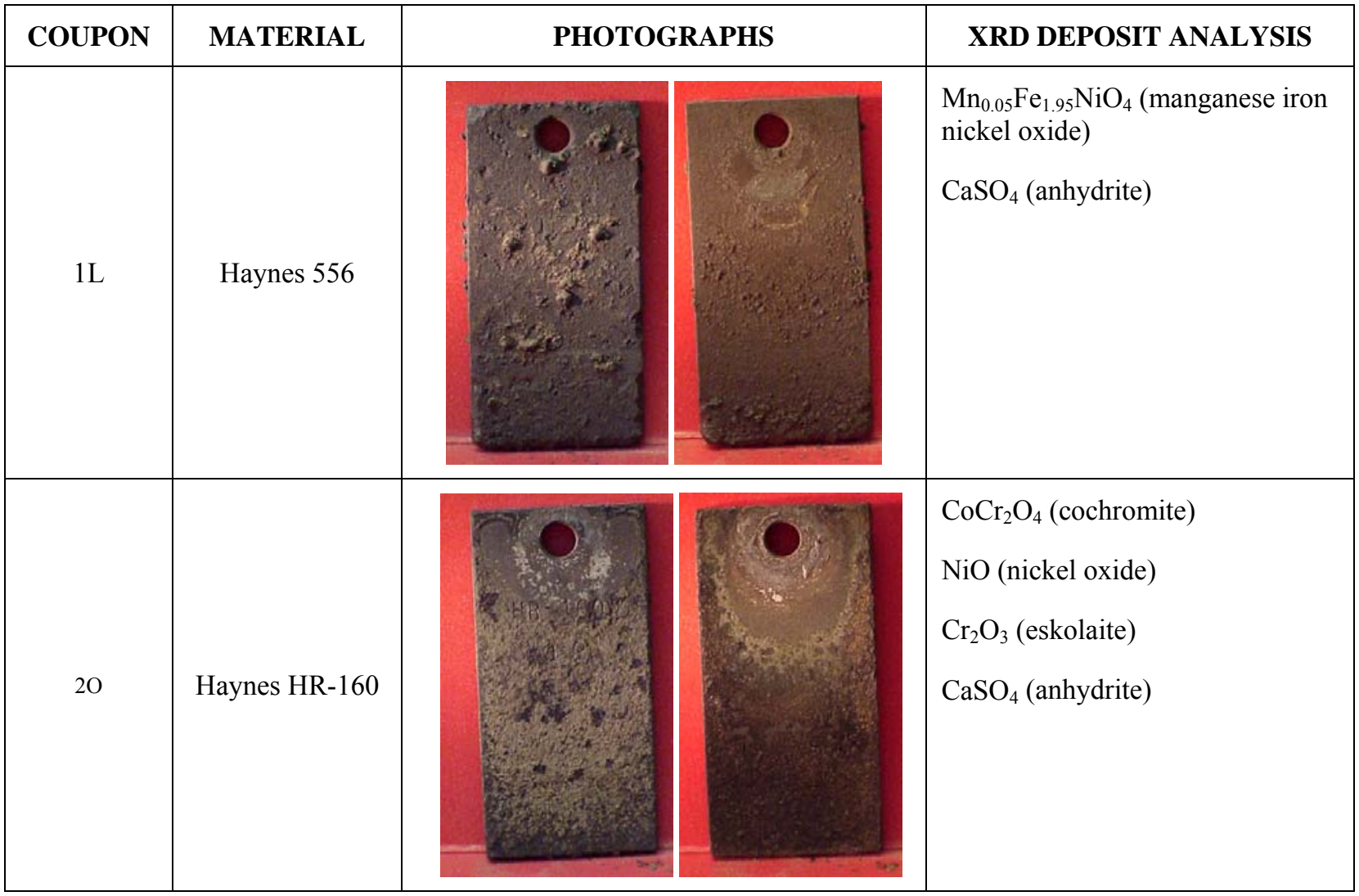




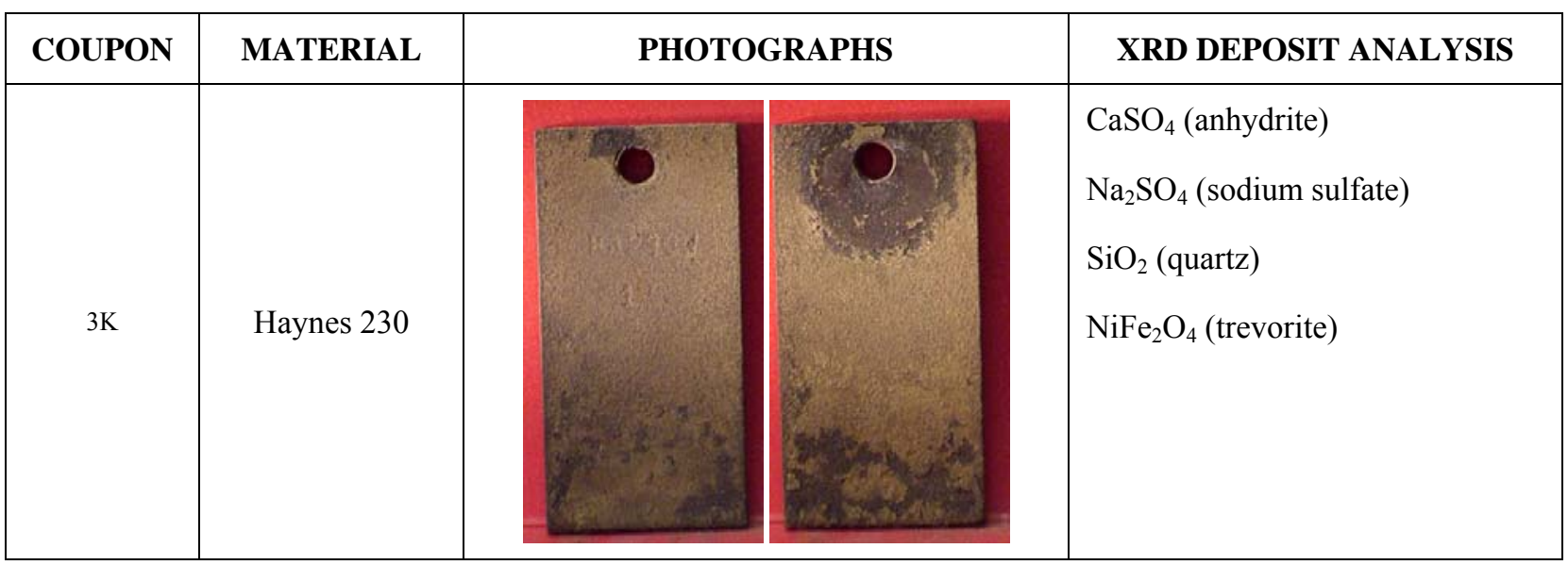

The metallographic analyses of the coupons are shown in Figure 39 - 41. The cross sections show surface dealloying with significant internal attack including IGA and pitting.
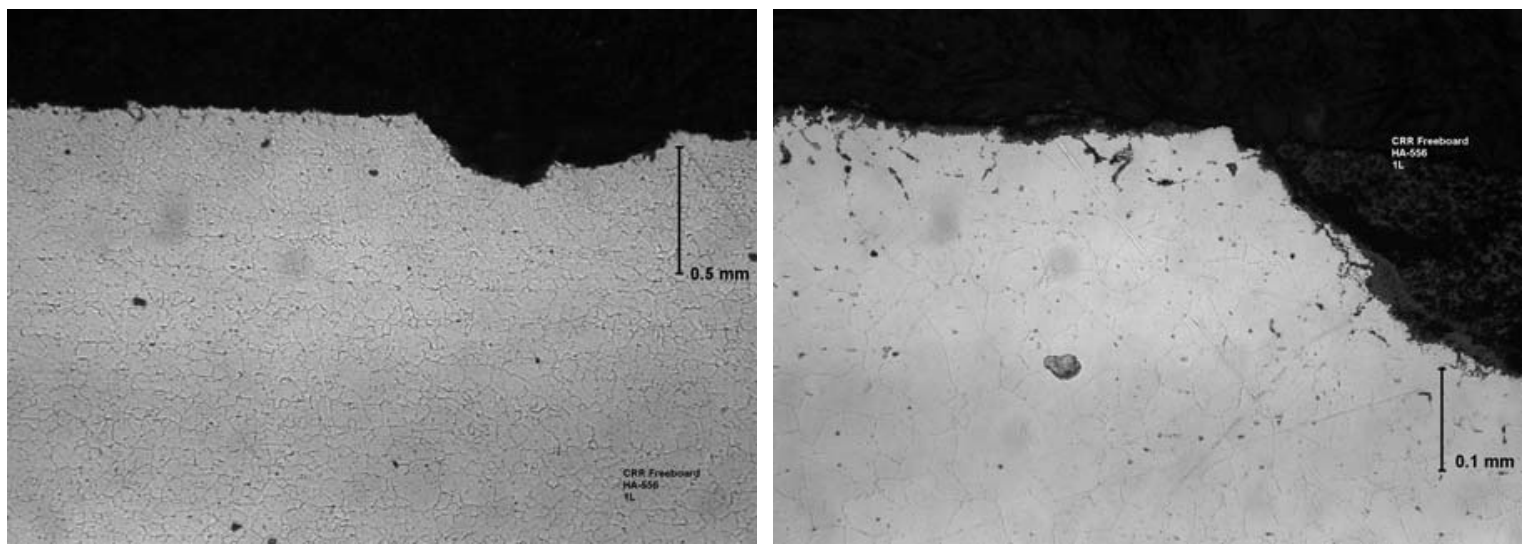

Figure 39: Metallographic Cross Section of Coupon 1L - Haynes 556 Alloy Exposed to CRR Freeboard
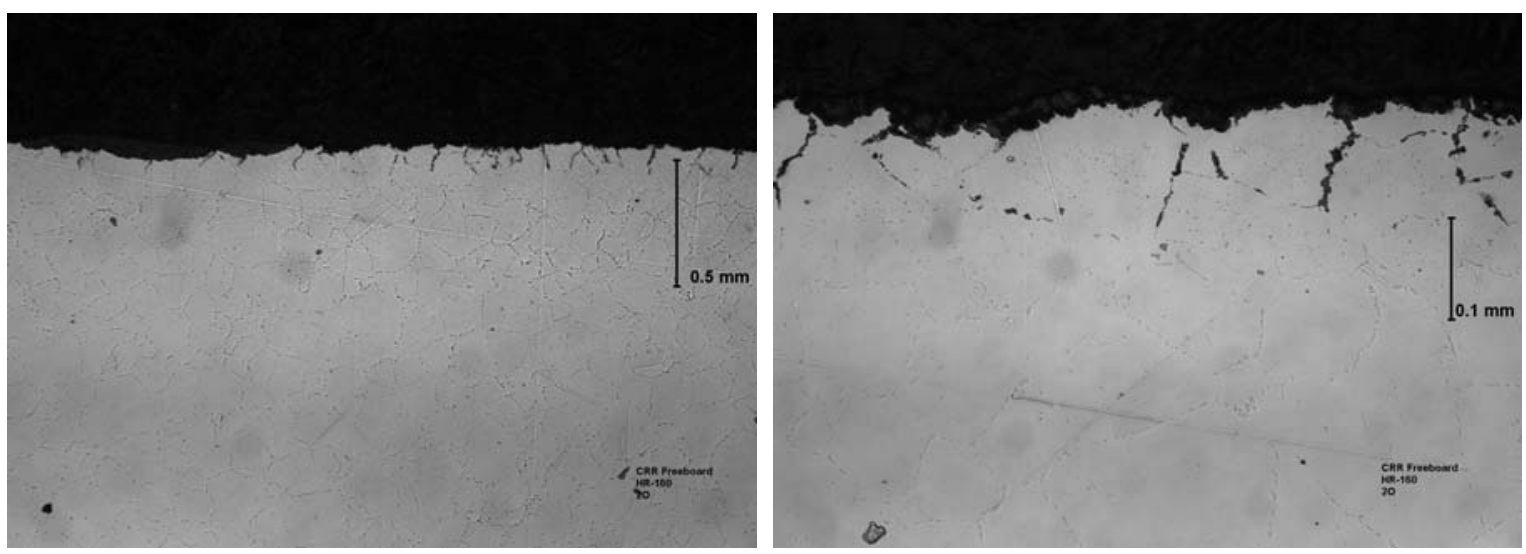

Figure 40: Metallographic Cross Section of Coupon 20 - Haynes Alloy HR-160 Exposed to CRR Freeboard 

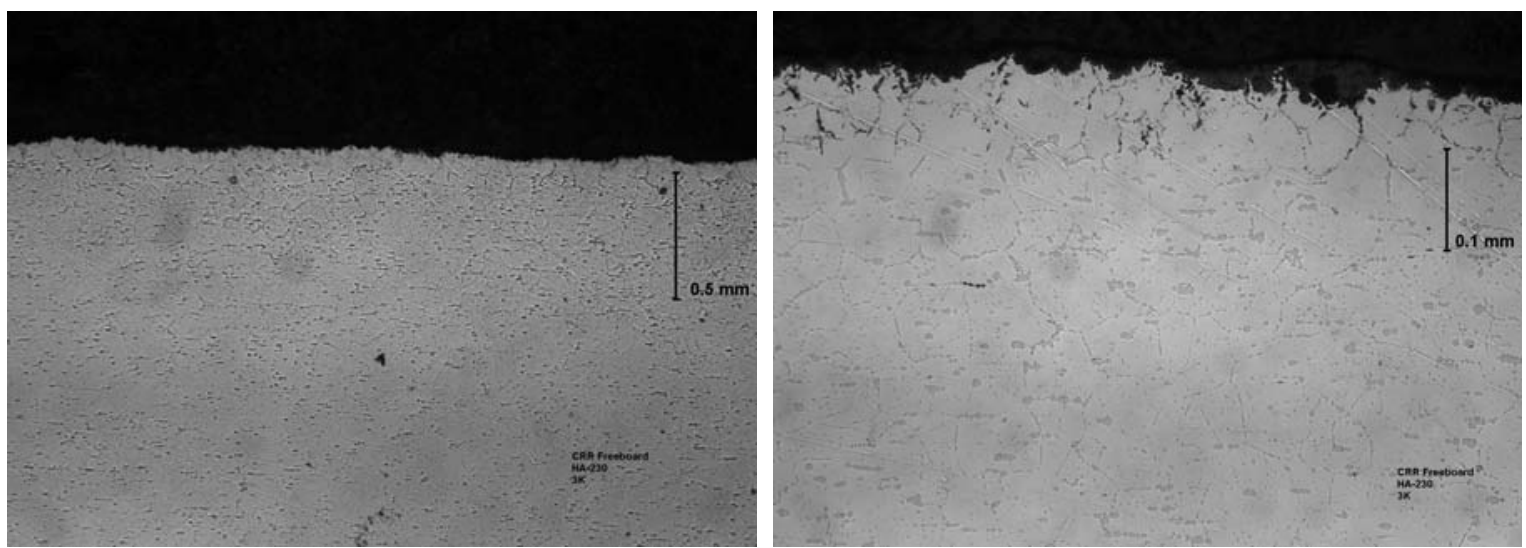

Figure 41: Metallographic Cross Section of Coupon 3K - Haynes 230 Alloy Exposed to CRR Freeboard

In the case of the coupons exposed to the CRR freeboard, the corrosion mechanisms are expected to be similar to the CRR bed. However, the temperatures may not be sufficient to form the stable silica layer in the samples, and the gas flows may be not equivalent to the coupons indicating differential corrosion in the coupons due simply to geometry. In this case, the Haynes 556 alloy performed better per calculations (as will be shown in the discussion sections) even though a silica layer was found on the Haynes 230 layer and a chromia layer was found on the HR160 alloy.

\subsubsection{Coupons Exposed to PBF Dirty Side}

The CRR process gas stream, now almost entirely nitrogen, oxygen, water vapor, and carbon dioxide, is cooled in the off-gas cooler (OGC) and scrubbed for trace acid gases in the Quencher/Scrubber (Q/S) system, reheated by the Reheater, and filtered in the Process Baghouse Filter (PBF). The corrosion coupons in the PBF section were mounted on the dirty side of the filter. The coupons were mounted vertically with one face out on a steel cylinder in the inlet to the filter, with one short edge (w/o) hole down in upward gas flow, as shown in Figure 42. The nominal temperature in this region $150^{\circ} \mathrm{C} \pm 10^{\circ} \mathrm{C}$.

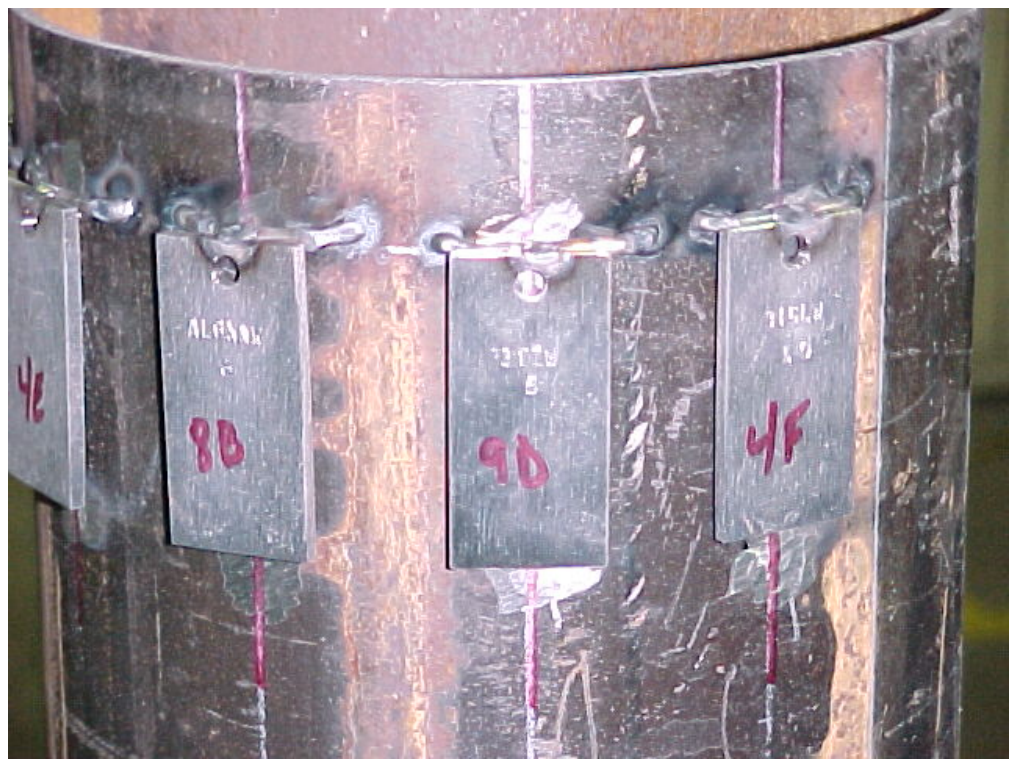

Figure 42: Coupon Exposed in the PBF

The pictures of the coupons are shown in Table 12. The coupons showed pervasive corrosion but not as extensive as other sections, based upon the visibility of the machining marks.. There was evidence of process deposits on the coupon, including sulfates, carbonates, and hydroxides. 
Table 12: Coupons Exposed to PBF Dirty Side

\begin{tabular}{|c|c|c|c|}
\hline COUPON & MATERIAL & SERIAL \# & XRD DEPOSIT ANALYSIS \\
\hline $8 \mathrm{~B}$ & AL6XN & & $\begin{array}{l}\text { Graphite } \\
\mathrm{CaSO}_{4}(\text { anhydrite) } \\
\mathrm{KFe}_{3}\left(\mathrm{SO}_{4}\right)_{2}(\mathrm{OH})_{6} \text { (jarosite) } \\
\mathrm{Fe}_{2}\left(\mathrm{CO}_{3}\right) \mathrm{OH} \text { (iron carbonate } \\
\text { hydroxide) }\end{array}$ \\
\hline 9D & $317 \mathrm{SS}$ & & $\begin{array}{l}\mathrm{CaSO}_{4} \text { (anhydrite) } \\
\text { Graphite }\end{array}$ \\
\hline $4 \mathrm{~F}$ & $316 \mathrm{~L} \mathrm{SS}$ & & $\begin{array}{l}\mathrm{Al}_{2} \mathrm{O}_{3} \text { (corundum) } \\
\mathrm{Ca}_{4} \mathrm{Al}_{2} \mathrm{O}_{6}\left(\mathrm{CrO}_{4}\right) \cdot \mathrm{H}_{2} \mathrm{O} \text { (calcium } \\
\text { aluminum chromium oxide hydrate) } \\
\text { Graphite }\end{array}$ \\
\hline
\end{tabular}

The metallographic analyses for the PBF coupons are shown in Figure $43-45$. The metallographic analysis indicates pervasive pitting with little intergranular attack beyond the pitting front. However, the AL6XN is a superaustenitic alloy with additional $\mathrm{Cr}$ and Mo to increase the pitting resistance when compared with conventional stainless steel. 

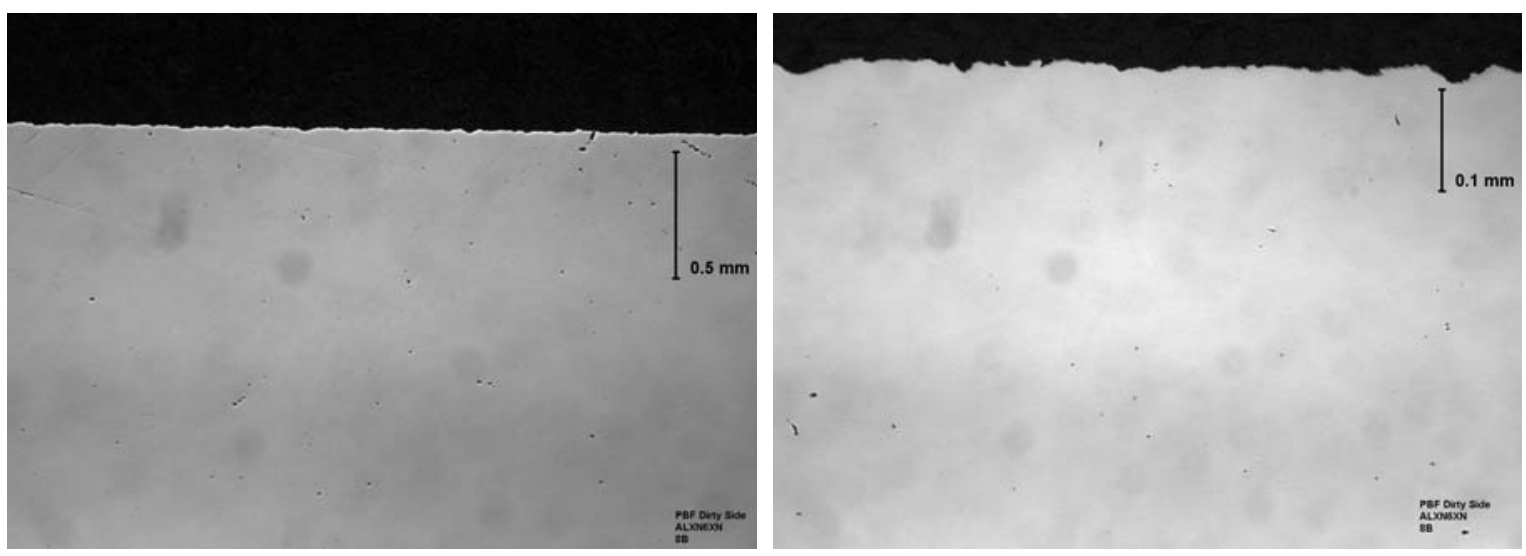

Figure 43: Metallographic Cross Section of Coupon 8B - Alloy AL6XN Exposed to PBF Dirty Side
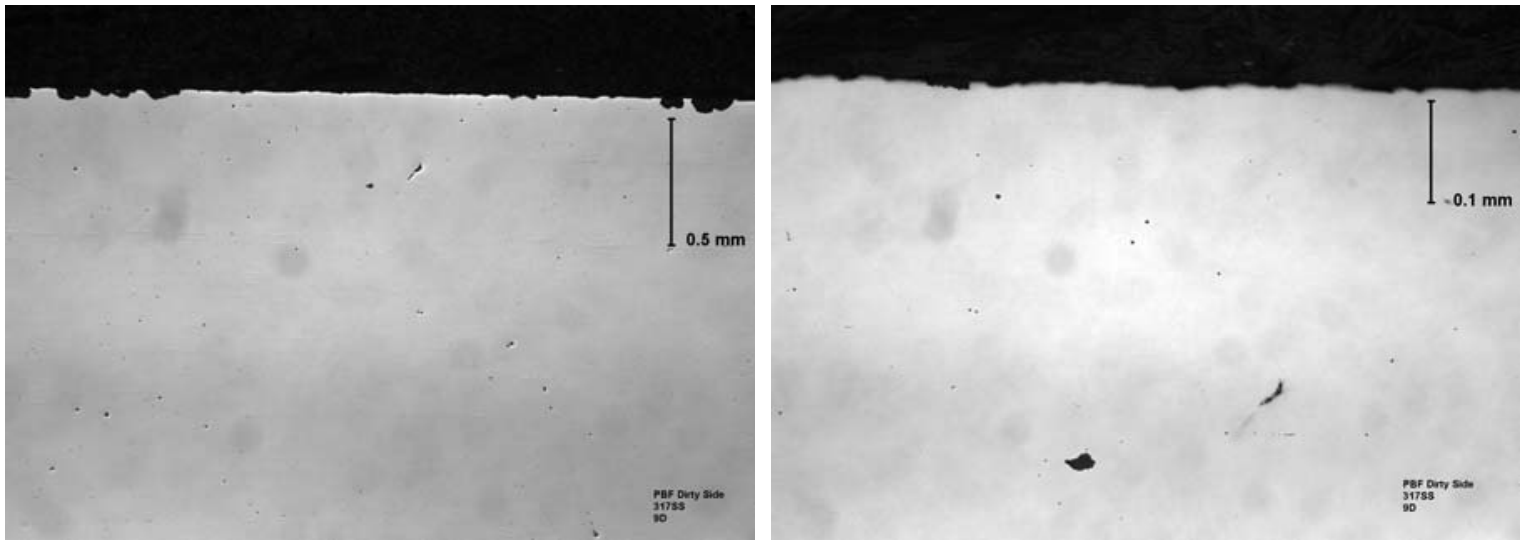

Figure 44: Metallographic Cross Section of Coupon 9D - 317SS Exposed to PBF Dirty Side

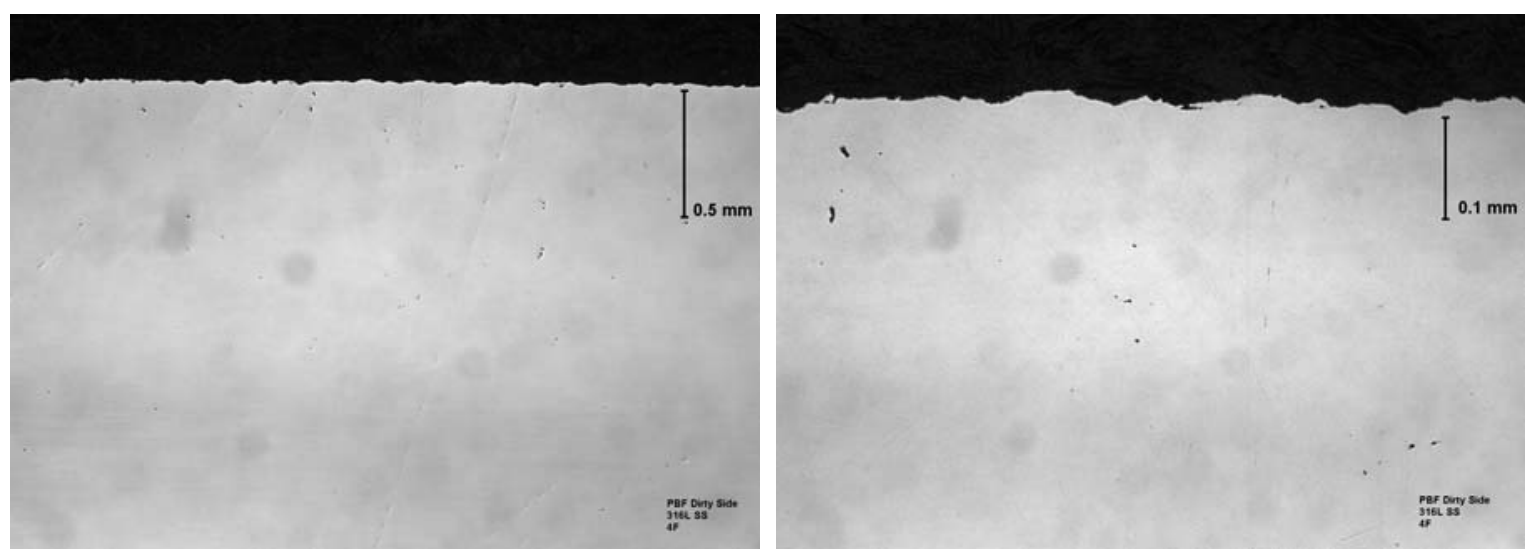

Figure 45: Metallographic Cross Section of Coupon 4F - 316L SS Exposed to PBF Dirty Side

\subsection{Microscopic Measurements}

The metallographic cross sections were used to measure the following parameters on the coupons:

- Metal loss

- Internal penetration is reported as IGA. 
- "Dealloying" depth reported. This dealloying occurred on the sample surface due to high temperature diffusion.

The coupons were measured on an $\mathrm{x}-\mathrm{y}$ traveling stage microscope. The average metal loss was measured, as the coupons exhibited relatively straight corrosion fronts. The average and maximum internal penetration were measured. These parameters were then used to calculate the following:

- Average metal affected and consequent average rate of attack

- Maximum metal affected and consequent maximum rate of attack.

Each of the various parameters was measured as shown in Figure 46.

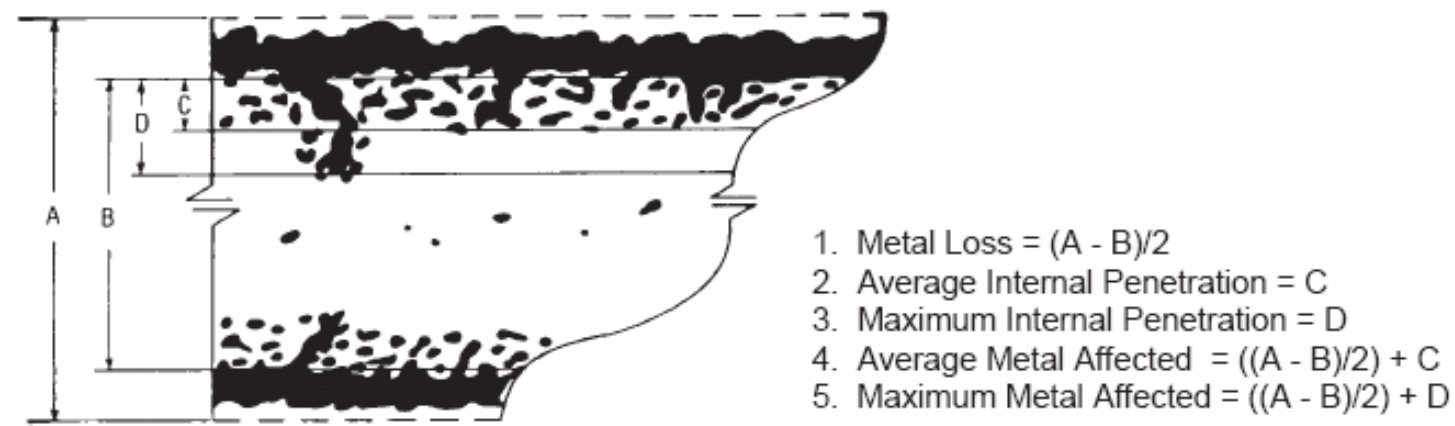

Figure 46: Measurements and Calculation of Depth of Penetration (Acknowledgement: Haynes Alloy 230 Brochure)

The exposure times of the coupons were based upon the exposure data shown in Table 13, per calculated exposures. The data has removed down times, and were cross-referenced to the temperature data provided.

Table 13: Exposure Data and Duration

\begin{tabular}{|c|c|}
\hline Location & $\begin{array}{c}\text { Hours } \\
\text { Exposure }\end{array}$ \\
\hline DMR Bed Coupons & 745 \\
\hline DMR Freeboard Coupons & 697 \\
\hline HTF Coupons & 751 \\
\hline CRR-Reducing Bed Coupons & 840 \\
\hline CRR Freeboard Coupons & 952 \\
\hline PBF Coupons & 1013 \\
\hline
\end{tabular}

The general metal loss rate is shown in Table 14. The depth and rate of internal attack on the coupons is shown in Table 15. The internal attack includes the IGA as well as pitting. The $4 \mathrm{C}$ stainless steel coupon exposed to the HTF dirty side data indicated a higher final thickness and the measurements could not be reconciled with a corrosion rate.

Table 14: General Metal Loss of Coupons

\begin{tabular}{|c|c|c|c|c|}
\hline Location & Coupon & Alloy & General Metal Loss (mm) & Rate (mm/yr) \\
\hline DMR in Bed & 1A & HA556 & 0.0108 & 0.1270 \\
\hline
\end{tabular}


WSRC-TR-2006-00142, Rev. 1

\begin{tabular}{|c|c|c|c|c|}
\hline Location & Coupon & Alloy & General Metal Loss (mm) & Rate $(\mathbf{m m} / \mathbf{y r})$ \\
\hline \multirow[t]{3}{*}{$(640 C)$} & $2 \mathrm{C}$ & HR160 & 0.0495 & 0.5820 \\
\hline & $3 E$ & HA230 & 0.1054 & 1.2387 \\
\hline & 4G & 316L & 0.2636 & 3.0995 \\
\hline DMR Freeboard & 1D & HA556 & 0.0213 & 0.2677 \\
\hline \multirow[t]{3}{*}{$(610 C)$} & $2 F$ & HR160 & 0.0520 & 0.6535 \\
\hline & $3 \mathbf{H}$ & HA230 & 0.1011 & 1.2706 \\
\hline & 4B & 316L & 0.0405 & 0.5090 \\
\hline CRR in Bed (RED) & $1 \mathrm{H}$ & Haynes 556 & 0.1873 & 1.9533 \\
\hline \multirow[t]{2}{*}{$(950 C)$} & $2 \mathrm{~A}$ & Haynes HR-160 & 0.0313 & 0.3264 \\
\hline & 3C & Haynes 230 & 0.0362 & 0.3775 \\
\hline CRR in Bed $(O X)$ & $1 \mathrm{~J}$ & Haynes 556 & 0.0861 & 1.9154 \\
\hline \multirow[t]{2}{*}{$(950 C)$} & $2 \mathrm{~L}$ & Haynes HR-160 & 0.1392 & 3.0938 \\
\hline & $3 \mathbf{N}$ & Haynes 230 & N/A & N/A \\
\hline CRR Freeboard & $1 \mathrm{~L}$ & Haynes 556 & 0.1228 & 1.1300 \\
\hline \multirow[t]{2}{*}{$(850 C)$} & 20 & Haynes HR-160 & 0.2195 & 2.0198 \\
\hline & 3K & Haynes 230 & 0.1912 & 1.7594 \\
\hline HTF Dirty Side & $1 \mathrm{E}$ & Haynes 556 & 0.0190 & 0.2216 \\
\hline Coupons & $2 G$ & Haynes HR-160 & 0.0209 & 0.2432 \\
\hline \multirow[t]{2}{*}{$(520 \mathrm{C})$} & 3A & Haynes 230 & 0.0279 & 0.3254 \\
\hline & $4 C$ & 316L SS & N/A & N/A \\
\hline \multirow[t]{3}{*}{ PBF Dirty Side } & 8B & AL6XN & 0.0814 & 0.7039 \\
\hline & 9D & $317 \mathrm{SS}$ & 0.2424 & 2.0962 \\
\hline & $4 F$ & 316L SS & 0.1845 & 1.5950 \\
\hline
\end{tabular}

Table 15: IGA of Coupons

\begin{tabular}{|c|c|c|c|c|c|c|}
\hline Location & Coupon & Alloy & $\begin{array}{c}\text { Average } \\
\text { Depth of } \\
\text { IGA }(\mu \mathrm{m})\end{array}$ & $\begin{array}{c}\text { Average } \\
\text { Rate of } \\
\text { IGA } \\
(\mu \mathbf{m} / \mathbf{y r})\end{array}$ & $\begin{array}{c}\text { Max Depth } \\
\text { of IGA } \\
(\mu \mathbf{m})\end{array}$ & $\begin{array}{c}\text { Max Rate } \\
\text { of IGA } \\
(\mu \mathbf{m} / \mathbf{y r})\end{array}$ \\
\hline DMR in Bed & 1A & HA556 & 0 & 0 & 0 & 0 \\
\hline (640C) & 2C & HR160 & 20 & 235 & 30 & 353 \\
\hline & 3E & HA230 & 0 & 0 & 0 & 0 \\
\hline 4G & 316L & 0 & 0 & 0 & 0 \\
\hline DMR Freeboard & 1D & HA556 & 8 & 101 & 8 & 101 \\
\hline (610C) & 2F & HR160 & 18 & 226 & 33 & 415 \\
\hline & 3H & HA230 & 5 & 63 & 5 & 63 \\
\hline
\end{tabular}


WSRC-TR-2006-00142, Rev. 1

\begin{tabular}{|c|c|c|c|c|c|c|}
\hline Location & Coupon & Alloy & $\begin{array}{c}\text { Average } \\
\text { Depth of } \\
\text { IGA }(\mu \mathrm{m})\end{array}$ & $\begin{array}{c}\text { Average } \\
\text { Rate of } \\
\text { IGA } \\
(\mu \mathbf{m} / \mathbf{y r}) \\
\end{array}$ & $\begin{array}{c}\text { Max Depth } \\
\text { of IGA } \\
(\mu \mathrm{m})\end{array}$ & $\begin{array}{c}\text { Max Rate } \\
\text { of IGA } \\
(\mu \mathrm{m} / \mathbf{y r})\end{array}$ \\
\hline & 4B & $316 \mathrm{~L}$ & 13 & 163 & 25 & 314 \\
\hline CRR in Bed (RED) & $1 \mathrm{H}$ & Haynes 556 & 0 & 0 & 0 & 0 \\
\hline \multirow[t]{2}{*}{$(950 C)$} & $2 A$ & Haynes HR-160 & 7 & 73 & 10 & 104 \\
\hline & $3 \mathrm{C}$ & Haynes 230 & 5 & 52 & 8 & 83 \\
\hline CRR in Bed (OX) & $1 \mathrm{~J}$ & Haynes 556 & 80 & 1779 & 200 & 4447 \\
\hline \multirow[t]{2}{*}{$(950 C)$} & $2 \mathrm{~L}$ & Haynes HR-160 & 350 & 7782 & 1000 & 22234 \\
\hline & $3 N$ & Haynes 230 & 33 & 734 & 84 & 1868 \\
\hline CRR Freeboard & $1 \mathrm{~L}$ & Haynes 556 & 22 & 202 & 48 & 442 \\
\hline \multirow[t]{2}{*}{$(850 C)$} & 20 & Haynes HR-160 & 89 & 819 & 100 & 920 \\
\hline & $3 K$ & Haynes 230 & 70 & 644 & 83 & 764 \\
\hline HTF Dirty Side & 1E & Haynes 556 & 2 & 23 & 2 & 23 \\
\hline Coupons & $2 \mathrm{G}$ & Haynes HR-160 & 8 & 93 & 5 & 58 \\
\hline \multirow[t]{2}{*}{$(520 \mathrm{C})$} & 3A & Haynes 230 & 0 & 0 & 0 & 0 \\
\hline & $4 \mathrm{C}$ & 316L SS & N/A & N/A & N/A & N/A \\
\hline \multirow[t]{3}{*}{ PBF Dirty Side } & 8B & AL6XN & 0 & 0 & 0 & 0 \\
\hline & 9D & $317 \mathrm{SS}$ & 6 & 52 & 8 & 69 \\
\hline & $4 F$ & 316L SS & 9 & 78 & 18 & 156 \\
\hline
\end{tabular}

The depth of dealloying on the coupons that exhibited the phenomenon is shown in Table 16.

Table 16: Depth of Dealloying (DeA) on Coupons

\begin{tabular}{|c|c|c|c|c|c|c|}
\hline Location & Coupon & Alloy & $\begin{array}{c}\text { Average } \\
\text { Depth of } \\
\text { DeA }(\boldsymbol{\mu m})\end{array}$ & $\begin{array}{c}\text { Average } \\
\text { Rate of } \\
\text { DeA } \\
(\mu \mathbf{m} / \mathbf{y r})\end{array}$ & $\begin{array}{c}\text { Max Depth } \\
\text { of DeA } \\
(\mu \mathbf{m})\end{array}$ & $\begin{array}{c}\text { Max Rate } \\
\text { of DeA } \\
(\mu \mathbf{m} / \mathbf{y r})\end{array}$ \\
\hline CRR in Bed (RED) & $\mathbf{1 H}$ & Haynes 556 & 70 & 730 & 90 & 939 \\
\hline (950C) & 2A & Haynes HR-160 & 170 & 1773 & 170 & 1773 \\
\hline & 3C & Haynes 230 & 100 & 1043 & 100 & 1043 \\
\hline CRR Freeboard & 1L & Haynes 556 & 17 & 156 & 43 & 396 \\
\hline (850C) & 20 & Haynes HR-160 & 0 & 0 & 0 & 0 \\
\hline & 3K & Haynes 230 & 0 & 0 & 0 & 0 \\
\hline
\end{tabular}

\section{DISCUSSION}

The data from the general corrosion and intergranular attack were used to infer potential corrosion mechanisms in each of the sections and make general observations on the coupons in terms of their alloying effects on the corrosion 
response.

\subsection{Calculation of Metal Affected}

These data were used to calculate the rates by which the metal is affected during the exposure. The rate of degradation using the average metal affected and maximum metal affected are shown in Table 17. The rates are shown in metric and SI units. The rate of corrosion reported in Table 17 is shown for a $100 \%$ operation throughout the year.

Table 17: Rate of Metal Affected of Coupons

\begin{tabular}{|c|c|c|c|c|c|c|}
\hline Location & Coupon & Alloy & $\begin{array}{c}\text { Average } \\
\text { Rate of } \\
\text { Metal } \\
\text { Affected } \\
(\mu \mathrm{m} / \mathrm{yr})\end{array}$ & $\begin{array}{c}\text { Max Rate } \\
\text { of Metal } \\
\text { Affected } \\
(\mu \mathrm{m} / \mathrm{yr})\end{array}$ & $\begin{array}{l}\text { Average } \\
\text { Rate of } \\
\text { Metal } \\
\text { Affected } \\
\text { (in/yr) }\end{array}$ & $\begin{array}{c}\text { Max Rate } \\
\text { of Metal } \\
\text { Affected } \\
\text { (in/yr) }\end{array}$ \\
\hline DMR in Bed & $1 \mathrm{~A}$ & HA556 & 127 & 127 & 0.0050 & 0.0050 \\
\hline \multirow[t]{3}{*}{ (640C) } & $2 \mathrm{C}$ & HR160 & 817 & 935 & 0.0322 & 0.0368 \\
\hline & $3 E$ & HA230 & 1239 & 1239 & 0.0488 & 0.0488 \\
\hline & $4 G$ & 316L & 3111 & 3100 & 0.1226 & 0.1221 \\
\hline DMR Freeboard & $1 D$ & HA556 & 368 & 368 & 0.0145 & 0.0145 \\
\hline \multirow[t]{3}{*}{ (610C) } & $2 F$ & HR160 & 880 & 1068 & 0.0347 & 0.0421 \\
\hline & 3H & HA230 & 1333 & 1333 & 0.0525 & 0.0525 \\
\hline & 4B & 316L & 672 & 823 & 0.0265 & 0.0324 \\
\hline CRR in Bed (RED) & $1 \mathrm{H}$ & Haynes 556 & 2683 & 2892 & 0.1057 & 0.1139 \\
\hline \multirow[t]{2}{*}{$(950 C)$} & $2 \mathrm{~A}$ & Haynes HR-160 & 2172 & 2204 & 0.0856 & 0.0868 \\
\hline & $3 \mathrm{C}$ & Haynes 230 & 1473 & 1504 & 0.0580 & 0.0592 \\
\hline CRR in Bed $(\mathrm{OX}) *$ & $1 \mathrm{~J}$ & Haynes 556 & 5584 & 8585 & 0.2200 & 0.3383 \\
\hline \multirow[t]{2}{*}{$(950 C)$} & $2 \mathbf{L}$ & Haynes HR-160 & 13766 & 28440 & 0.5424 & 1.1205 \\
\hline & $3 \mathbf{N}$ & Haynes 230 & 734 & 1868 & 0.0289 & 0.0736 \\
\hline CRR Freeboard & $1 \mathrm{~L}$ & Haynes 556 & 1489 & 1967 & 0.0587 & 0.0775 \\
\hline \multirow[t]{2}{*}{ (850C) } & 20 & Haynes HR-160 & 2839 & 2940 & 0.1118 & 0.1158 \\
\hline & $3 K$ & Haynes 230 & 2403 & 2523 & 0.0947 & 0.0994 \\
\hline HTF Dirty Side & $1 \mathrm{E}$ & Haynes 556 & 245 & 245 & 0.0097 & 0.0097 \\
\hline Coupons & $2 G$ & Haynes HR-160 & 337 & 302 & 0.0133 & 0.0119 \\
\hline \multirow[t]{2}{*}{ (520C) } & 3A & Haynes 230 & 384 & 384 & 0.0151 & 0.0151 \\
\hline & $4 \mathrm{C}$ & 316L SS & N/A & $\mathrm{N} / \mathrm{A}$ & N/A & $\mathrm{N} / \mathrm{A}$ \\
\hline \multirow[t]{3}{*}{ PBF Dirty Side } & 8B & AL6XN & 704 & 704 & 0.0277 & 0.0277 \\
\hline & 9D & $317 \mathrm{SS}$ & 2148 & 2165 & 0.0846 & 0.0853 \\
\hline & $4 F$ & 316L SS & 1673 & 1751 & 0.0659 & 0.0690 \\
\hline
\end{tabular}

* The data for the oxidizing portion are reported per the procedure of measurement, however, the coupons exhibited significant macro-scale attack. This macro-scale attack is considered, and a refractory protection for the structural metal is recommended for this section. The metal must be sealed completely preventing a potentially more detrimental crevice situation.

The corrosion per hour of operation is shown in Table 18. This data can be used to determine a customer-defined corrosion allowance that takes into account the following assumptions in a safety factor: 
- The corrosion coupon data reported includes general corrosion and IGA. The IGA is complex to include in a corrosion allowance due to its dependence on localized conditions.

- The corrosion coupons do not account for system stresses that vessels may experience during service, e.g. thermal, dynamic loads due to pressure.

Table 18: Calculation of Corrosion Rate per Hour of Operation

\begin{tabular}{|c|c|c|}
\hline Location & Alloy & Corrosion Rate Per Hr/Operation (in./hr) \\
\hline \multirow[t]{4}{*}{ DMR in Bed } & HA556 & $5.71 \mathrm{E}-07$ \\
\hline & HR160 & $3.67 \mathrm{E}-06$ \\
\hline & HA230 & $5.57 \mathrm{E}-06$ \\
\hline & 316L & $1.40 \mathrm{E}-05$ \\
\hline \multirow[t]{4}{*}{ DMR Freeboard } & HA556 & $1.66 \mathrm{E}-06$ \\
\hline & HR160 & $3.95 \mathrm{E}-06$ \\
\hline & HA230 & 5.99E-06 \\
\hline & $316 \mathrm{~L}$ & $3.02 \mathrm{E}-06$ \\
\hline \multirow[t]{3}{*}{ CRR in Bed (RED) } & Haynes 556 & $1.21 \mathrm{E}-05$ \\
\hline & Haynes HR-160 & $9.76 \mathrm{E}-06$ \\
\hline & Haynes 230 & $6.62 \mathrm{E}-06$ \\
\hline \multirow[t]{3}{*}{ CRR in Bed (OX) } & Haynes 556 & $\mathrm{~N} / \mathrm{A}$ \\
\hline & Haynes HR-160 & N/A \\
\hline & Haynes 230 & N/A \\
\hline \multirow[t]{3}{*}{ CRR Freeboard } & Haynes 556 & $6.69 \mathrm{E}-06$ \\
\hline & Haynes HR-160 & $1.28 \mathrm{E}-05$ \\
\hline & Haynes 230 & $1.08 \mathrm{E}-05$ \\
\hline HTF Dirty Side & Haynes 556 & $1.10 \mathrm{E}-06$ \\
\hline \multirow[t]{3}{*}{ Coupons } & Haynes HR-160 & $1.51 \mathrm{E}-06$ \\
\hline & Haynes 230 & $1.72 \mathrm{E}-06$ \\
\hline & 316L SS & N/A \\
\hline \multirow[t]{3}{*}{ PBF Dirty Side } & AL6XN & $3.16 \mathrm{E}-06$ \\
\hline & 317 SS & $9.65 \mathrm{E}-06$ \\
\hline & 316L SS & 7.52E-06 \\
\hline
\end{tabular}

The average and maximum metal affected calculations were used to calculate the metal affected over a 5 year exposure period. The results are shown in Table 19. An $80 \%$ on-line time was assumed for the calculations, i.e. 4 years of exposure in 5-years service. 
Table 19: Total Metal Affected in 5 Years

\begin{tabular}{|c|c|c|c|c|}
\hline Location & Coupon & Alloy & $\begin{array}{c}\text { Total } \\
\text { Average } \\
\text { Metal } \\
\text { Affected in } \\
5 \text { years (in.) } \\
\text { (TAMA) }\end{array}$ & $\begin{array}{l}\text { Total Max } \\
\text { Metal } \\
\text { Affected in } \\
5 \text { years (in.) } \\
\text { (TMMA) }\end{array}$ \\
\hline DMR in Bed & $1 \mathrm{~A}$ & HA556 & 0.020 & 0.020 \\
\hline \multirow[t]{3}{*}{$(640 C)$} & $2 \mathrm{C}$ & HR160 & 0.129 & 0.147 \\
\hline & $3 \mathbf{E}$ & HA230 & 0.195 & 0.195 \\
\hline & 4G & $316 \mathrm{~L}$ & 0.490 & 0.488 \\
\hline DMR Freeboard & 1D & HA556 & 0.058 & 0.058 \\
\hline \multirow[t]{3}{*}{$(610 C)$} & $2 F$ & HR160 & 0.139 & 0.168 \\
\hline & $3 \mathbf{H}$ & HA230 & 0.210 & 0.210 \\
\hline & $4 B$ & $316 \mathrm{~L}$ & 0.106 & 0.130 \\
\hline CRR in Bed (RED) & $1 \mathrm{H}$ & Haynes 556 & 0.423 & 0.456 \\
\hline \multirow[t]{2}{*}{ (950C) } & 2A & Haynes HR-160 & 0.342 & 0.347 \\
\hline & $3 C$ & Haynes 230 & 0.232 & 0.237 \\
\hline CRR in Bed (OX) & $1 \mathrm{~J}$ & Haynes 556 & 0.880 & 1.353 \\
\hline \multirow[t]{2}{*}{$(950 C)$} & $2 \mathrm{~L}$ & Haynes HR-160 & 2.170 & 4.482 \\
\hline & $3 \mathbf{N}$ & Haynes 230 & 0.116 & 0.294 \\
\hline CRR Freeboard & $1 \mathrm{~L}$ & Haynes 556 & 0.235 & 0.310 \\
\hline \multirow[t]{2}{*}{$(850 C)$} & 20 & Haynes HR-160 & 0.447 & 0.463 \\
\hline & $3 \mathbf{K}$ & Haynes 230 & 0.379 & 0.398 \\
\hline HTF Dirty Side & $1 E$ & Haynes 556 & 0.039 & 0.039 \\
\hline Coupons & 2G & Haynes HR-160 & 0.053 & 0.048 \\
\hline \multirow[t]{2}{*}{ (520C) } & 3A & Haynes 230 & 0.060 & 0.060 \\
\hline & $4 \mathrm{C}$ & 316L SS & N/A & N/A \\
\hline \multirow[t]{3}{*}{ PBF Dirty Side } & 8B & AL6XN & 0.111 & 0.111 \\
\hline & 9D & 317 SS & 0.339 & 0.341 \\
\hline & $4 F$ & 316L SS & 0.264 & 0.276 \\
\hline
\end{tabular}

From the average metal affected data, it is seen that the Haynes 556 alloy performed the best in the DMR bed and DMR freeboard regions. Furthermore, the Haynes 556 alloy also performed the best in the CRR freeboard region, while the Haynes 230 alloy performed the best in the reducing side of the CRR bed. This was primarily due to the dealloying of the HR-160 alloy in this region.

\section{RECOMMENDATIONS}

The alloy that performed the best in the exposure with the known assumptions is shown in Table 20 .

Recommendations on alloy selection for each section of the $\mathrm{THOR}^{\mathrm{sm}}$ treatment process were made based upon the 
cumulative metal loss in a coupon referred to as the metal affected data. The metal affected data were used to calculate a corrosion rate per hour of operation based upon location-specific uniform exposure. The uniform exposure assumes that each of the coupons in the various sections was mounted such that they were equivalently exposed. However, the results and the deposits analysis indicate that orientation or placement in the system can influence the coupon performance. It appears that several coupons were protecting other coupons from corrosion.

The data can be used to calculate a corrosion allowance based upon a customer-defined safety factor.

Table 20: Alloy of Best Performance in Each Location

\begin{tabular}{|c|c|c|}
\hline Location & Alloy & $\begin{array}{c}\text { Corrosion Rate per hour } \\
\text { of operation(in./hr) }\end{array}$ \\
\hline DMR in Bed & HA556 & $5.71 \mathrm{E}-07$ \\
\hline DMR Freeboard & HA556 & $1.66 \mathrm{E}-06$ \\
\hline CRR in Bed (RED) & Haynes 230 & $6.62 \mathrm{E}-06$ \\
\hline CRR in Bed (OX) & N/A & $\begin{array}{c}\text { Needs protection with high } \\
\text { temperature refractory }\end{array}$ \\
\hline CRR Freeboard & Haynes 556 & $6.69 \mathrm{E}-06$ \\
\hline HTF Dirty Side & Haynes 556 & $1.10 \mathrm{E}-06$ \\
\hline PBF Dirty Side & AL6XN & $3.16 \mathrm{E}-06$ \\
\hline
\end{tabular}

The corrosion environment for the current case was postulated to be analogous to other processes wherein large number of contaminants are present in the waste stream. The gasses formed are severely corrosive and the ash/salt deposits can be highly corrosive in the high temperature regime as well as during down-time corrosion. In this case, the Haynes 556 alloy seems to have performed better than the HR-160 alloys and the Haynes 230 alloys in the broad sense. An analysis of the literature comparison of these two alloys indicates that the HR-160 alloys were developed for resistance to sulfidizing environments while the HA-556 alloys performs better in chloride containing environments and has a broader resistance to corrosion. [13] The data obtained in the analyses is consistent with those observed in the literature. 


\section{REFERENCES}

[1] D. Dustin, "Pilot Plant Testing Plan for Treating Sodium-Bearing Waste Surrogates Using the THOR ${ }^{\mathrm{SM}}$ Steam Reforming Process, Rev. 1" Project Number: 28276, Document Number: 28276-21-0015-01, Washington Group International, Denver CO, October 2005.

[2] "Pocket Guide to Materials Performance in Industrial High Temperature Environments," Haynes International, Kokomo, IN, 2004.

[3] W. Z. Friend, Corrosion of Nickel and Nickel-Base Alloys, John Wiley and Sons, 1980.

[4] R.F. Decker, "Strengthening Mechanisms of Nickel-Based Superalloys," 1969.

[5] H.E. Evans, et. al., Oxidation of Metals, 19, 1 (1983).

[6] M. Hansen and K. Anderko, Constitution of Binary Alloys, McGraw-Hill, New-York, 1958.

[7] G. Lai, Paper No. 209, National Association of Corrosion Engineers, Houston, TX, 1989.

[8] R.L. Tapping, E.G. McVey, and D.J. Diney, "Corrosion of Metallic Materials in The CRNL Radwaste Incinerator," presented at Chemical Waste Incineration Conference, March 1990, Manchester, UK.

[9] K. Natesan and Y.Y. Liu, "Erosion-Corrosion of Materials at Elevated Temperatures," Materials Science and Engineering, A121 (1989), p. 571-580.

[10] I.G. Wright, V. Nagarajan, J. Stringer, "Observation on the Role of Oxide Scales in High-Temperature Erosion-Corrosion," Oxidation of Metals, 25 (1986), p. 175-199.

[11] H.E. Evans, D.A. Hilton, R.A. Holm, "Influence of Silicon Additions on the Oxidation Resistance of Stainless Steel," Oxidation of Metals, 19(1) (1983), p.1-18.

12 H.E. Evans, D.A. Hilton, R.A. Holm, S.J. Webster, “The Development of Localized Pits During Stainless Steel Oxidation, Oxidation of Metals, 14(3) (1980) p.235.

[13] C.M. Antony, G.Y. Lai, S.K. Srivastava, "Materials Selection for Waste Incineration/Resource Recovery Equiopment," Waste Management, 11 (1991) p. 71-78. 